UNIVERSIDADE DE SÃO PAULO

ESCOLA DE COMUNICAÇÕES E ARTES

PROGRAMA DE PÓS-GRADUAÇÃO EM CIÊNCIA DA INFORMAÇÃO

\title{
A ORGANIZAÇÃO DA INFORMAÇÃO E A ORGANIZAÇÃO DO CONHECIMENTO NA PRODUÇÃO CIENTÍFICA EM CIÊNCIA DA INFORMAÇÃO
}

IRACI OLIVEIRA RODRIGUES

São Paulo

2015 


\section{IRACI OLIVEIRA RODRIGUES}

\section{A Organização da Informação e a Organização do Conhecimento na produção científica em Ciência da Informação}

(Versão corrigida)

Dissertação de Mestrado apresentada ao Programa de Pós-Graduação em Ciência da Informação da Escola de Comunicações e Artes da Universidade de São Paulo, como requisito parcial para obtenção do título de mestre em Ciência da Informação, sob orientação do Prof. Dr. Marivalde Moacir Francelin.

Área de concentração: Cultura e Informação.

Linha de pesquisa: Organização da Informação e do Conhecimento.

De acordo:

Orientador

São Paulo

2015

A versão original se encontra disponível na Biblioteca da ECA/USP 
Autorizo a reprodução e divulgação total ou parcial deste trabalho, por qualquer meio convencional ou eletrônico, para fins de estudo e pesquisa, desde que citada a fonte.

Catalogação na Publicação

Serviço de Biblioteca e Documentação

Escola de Comunicações e Artes da Universidade de São Paulo Dados fornecidos pelo(a) autor(a)

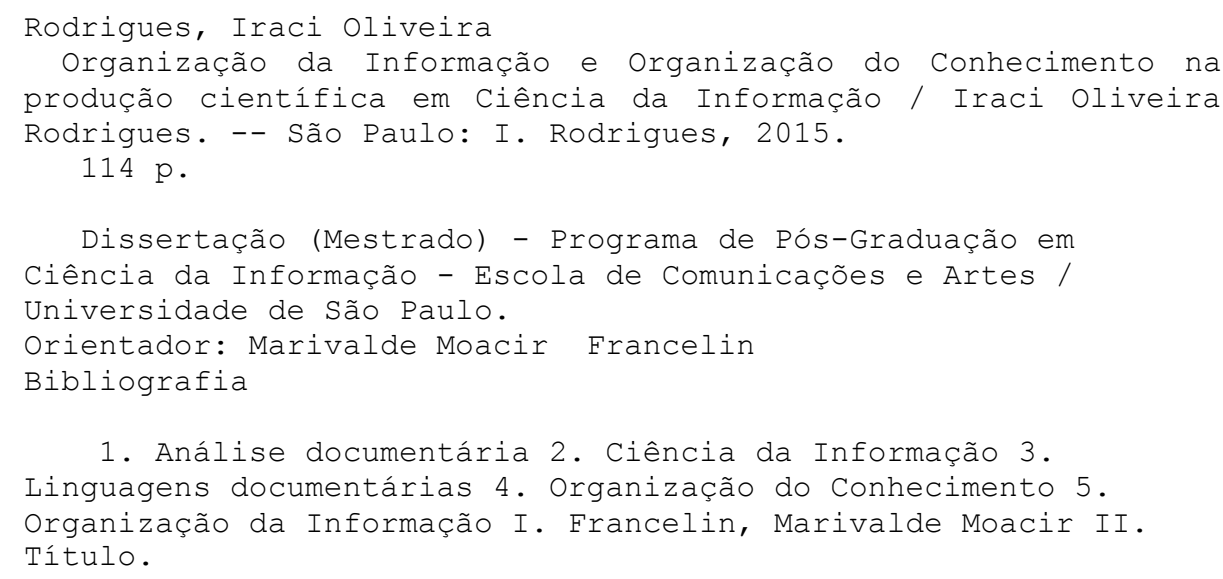


Iraci Oliveira Rodrigues

A Organização da Informação e a Organização do Conhecimento na produção científica em Ciência da Informação

Dissertação de Mestrado apresentada como requisito para a obtenção do grau de Mestre ao Programa de Pós-Graduação em Ciência da Informação (PPGCI), área de concentração Cultura e Informação, linha de pesquisa Organização da Informação e do Conhecimento, Escola de Comunicações e Artes, Universidade de São Paulo.

Banca Examinadora:

Prof. Dr. Marivalde Moacir Francelin (Orientador)

Universidade de São Paulo

Profa. Dra. Cibele Araújo Camargo Marques dos Santos

Universidade de São Paulo

Prof. Dr. João de Melo Maricato

Universidade Federal de Goiás

São Paulo, 


\section{Agradecimentos}

À minha família, que sempre me incentivou e possibilitou que continuasse os estudos, em especial à minha mãe, Elizete, e meu irmão Evandro.

Aos meus amigos do CBD, com os quais discuti os temas de pesquisa ao longo da sua elaboração e com que pude contar todos esses anos nesta Escola, em especial à Patrícia Cristina Rodrigues de Oliveira. Aos meus outros tantos amigos, sem os quais eu não teria mantido a leveza da vida, tão necessária para desenvolver uma pesquisa. Obrigada Vanderlei, Eleny Fernandes, Thaís Pereira, João Carlos Oliveira, Denise Rodriane L. Moura e Michelle Brasil. Aos meus colegas de trabalho e aos gestores, por compreenderem a dinâmica e tempos da pesquisa.

Aos professores do CBD que contribuíram para minha formação, agradeço às Prof. Dra. Nair Yumiko Kobashi e à Prof. Dra. Vânia Lima, pelas dicas preciosas durante a pesquisa.

À Prof. Dra. Cibele Araújo Camargo Marques dos Santos e ao Prof. Dr. João de Melo Maricato por integrarem a banca e contribuírem para discussão do tema.

E, em especial, agradeço ao Prof. Dr. Marivalde Moacir Francelin pela condução na orientação, encaminhamento das discussões, por todo o meu aprendizado em "fazer pesquisa", obrigada.

E a todos que de alguma maneira contribuíram para a realização desta pesquisa 
"Descobrir consiste em olhar para o que todo mundo está vendo e pensar uma coisa diferente."

(Roger Von Oech) 


\title{
Resumo
}

Impulsionada pela imprecisão conceitual apontada pelo uso dos termos Organização da Informação e Organização do Conhecimento na área de Ciência da Informação, a pesquisa teve por objetivo verificar como a Organização da Informação e Organização do Conhecimento aparecem representadas na produção científica de Ciência da Informação, e se há relação temática estabelecida com a Análise Documentária e as Linguagens Documentárias. A hipótese levantada versa sobre a possibilidade do tema organização da informação aparecer primeiro nas discussões da literatura da área. Foi realizada pesquisa exploratória com base em revisão bibliográfica e pesquisa empírica em bases referências, grupos e programas de pesquisa em Ciência da Informação. Dentre os resultados verificados, foi possível aferir o maior uso do termo "organização da informação" em comparação ao uso do termo "organização do conhecimento", mas não foi possível confirmar a hipótese do uso primeiro de nenhum dos termos na descrição da produção científica. A forma de representação temática dos trabalhos indicou uma distinção entre Organização da Informação e Organização do Conhecimento. A pesquisa aponta que as relações entre Organização da Informação e Organização do Conhecimento com a Análise Documentária indicam a possibilidade da ocorrência de substituição/superação/incorporação dessa área. Já os instrumentos de Linguagem Documentária são notados em descrição conjunta com os termos de buscas alvo da pesquisa.

Palavras-chave: Ciência da Informação. Organização da Informação. Organização do Conhecimento. Análise Documentária. Linguagens Documentárias.

\begin{abstract}
Stimulated by the imprecision conceptual pointed by the use of the terms Organization of the Information and Organization of the Knowledge in Science Information area, the research has had as an objective to check how the Organization of the Information and Organization of the knowledge were represented on the scientific production of Science Information, and if there is thematic relation established with the Documentary Analysis and Documentary Languages. The hypothesis raised examines about the possibility of the issue Organization of the Information emerge first at the discussions of the literature area. It was done an exploratory research with basis in bibliography review and an empirical research in basis references, groups and research programs in Science Information. Among the checked results, it was possible to compare the greatest use "organization of the information" comparing to "organization of the knowledge", but it was not possible to confirm the hypothesis of the first use of none terms on the scientific production description. The form of thematic
\end{abstract}


representation of the works indicated a distinction between Organization of the Information and Organization of the knowledge with the Documentary Analysis indicates the possibility of the occurrence substitution/overcoming/incorporation of this area. Now the Documentary Language instruments are noticed in description joint with the terms of pointed searches of the research.

Keyswords: Information Science. Information Organization. Knowledge Organization. Documentary Analysis. Languages Documentary. 


\section{Sumário}

Introdução

1. Questões introdutórias sobre a precisão conceitual na Organização da Informação e

Organização do Conhecimento .................................................................................... 13

2. Organização da Informação e Organização do Conhecimento...................................... 16

3. Análise Documentária: a configuração teórica do campo de conhecimento ................ 21

3.1 Vertentes teóricas de fundamentação da Análise Documentária ........................... 25

3.2 A configuração interdisciplinar da Análise Documentária ....................................... 26

4. A fundamentação teórica dos processos de organização e representação do conhecimento e da informação e as contribuições da Análise Documentária 29

4.1 Linguagem documentária: trajetória teórica, procedimentos de elaboração e utilização

4.2 Contribuições do paradigma sócio-cognitivo para a compreensão dos processos de organização e recuperação da informação ................................................................. 35

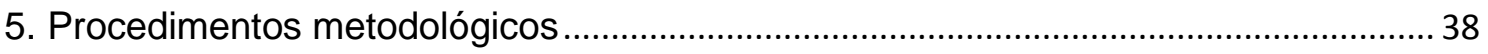

5.1 Análise e discussão dos resultados............................................................................. 43

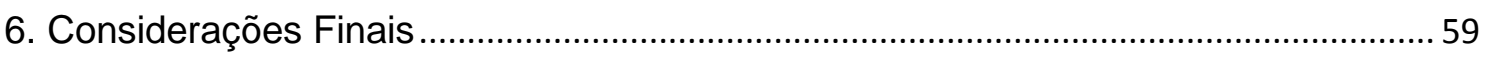

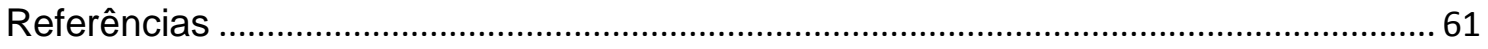

Apêndice A - Total do corpus selecionado (artigos, teses, dissertações e trabalhos em evento).

Apêndice B - Tabela 4 - Termos que ocorrem juntos com a produção científica descrita com os termos OI (organização da informação); OC (organização do conhecimento); OI/OC (organização da informação/organização do conhecimento) 


\section{Introdução}

Sabendo que o reconhecimento e a consolidação de uma área de conhecimento passam pela sistematização de suas práticas e pela definição dos seus pressupostos teóricos, os trabalhos em Ciência da Informação que se empenham nesse propósito visam contribuir para que a área se fortaleça internamente. Esse fortalecimento ocorre nas suas práticas e no reconhecimento científico frente às outras áreas do conhecimento, indicando o lugar da Ciência da Informação no contexto científico, como área de conhecimento independente, como ambiente de práticas e preocupações específicas.

Alguns dos elementos importantes na configuração de uma área de conhecimento são a precisão conceitual, a linguagem específica da área e a forma de representação do campo. Quando a área em questão é a Ciência da Informação, todos esses elementos acabam por ter uma relevância ainda maior, uma vez que a Ciência da Informação tem como uma das suas características de área de conhecimento a preocupação com a organização, a representação e a precisão conceitual, para fins de recuperação da informação registrada.

Sendo assim, a questão posta é de como a própria área de Ciência da Informação se comporta em relação a esses elementos. Como exemplo, Marisa Bräscher e Ligia Café, em comunicação realizada no IX ENANCIB (Encontro Nacional de Pesquisa em Pós-Graduação em Ciência da Informação), já apontaram problemas internos da área quando do emprego dos termos "Organização da Informação" e "Organização do Conhecimento". Na pesquisa realizada pelas autoras,

Os termos organização do conhecimento e organização da informação têm sido utilizados em diferentes contextos para denominar instituições, grupos e linhas de pesquisa, disciplinas e cursos na área de Ciência da Informação.

No entanto, a análise do emprego desses termos nesses contextos revela falta de clareza quanto à delimitação do conceito. Por vezes o termo organização do conhecimento é utilizado no sentido de organização da informação e vice-versa 
e, em determinadas situações, empregam-se os termos conjuntamente - organização da informação e do conhecimento. (BRASCHER; CAFÉ, 2008, p. 2)

E, se considerarmos o histórico de produção científica da área de Ciência da Informação, os estudos que se preocupam com a organização da informação - no sentido de informação registrada -, estão presentes desde seus primeiros estudos teóricos e metodológicos.

Ainda, ao considerar a conformação da Ciência da Informação como área de conhecimento a partir da sua produção científica, poderia ser considerada a hipótese do emprego mais tardio da expressão "organização do conhecimento".

Mas, a preocupação da atual pesquisa não é traçar um histórico de uso dos termos "Organização da Informação" e "Organização do Conhecimento" e sim tentar compreender como se configura atualmente a pesquisa e a produção científica sobre a Organização da Informação e sobre a Organização do Conhecimento e como está apresentada a Análise Documentária nesse contexto.

Como objetivos específicos, buscou-se mapear a produção científica em Ciência da Informação representada com os termos Organização da Informação e Organização do Conhecimento, considerando informações como ano de produção e termos relacionados, a fim de mostrar como a área se configura através de termos associados, evidenciando questões interdisciplinares e tendências de pesquisa.

Outro objetivo a ser alcançado se refere à compreensão das áreas de Organização da Informação e Organização do Conhecimento como comunidades de produção científica, com atores e instituições atuantes no cenário brasileiro.

Para alcançar os objetivos traçados na pesquisa, a metodologia adotada consistiu em iniciar os trabalhos com considerações introdutórias 
sobre a área de Organização da Informação dentro da Ciência da Informação. A revisão também procurou trazer algumas discussões referentes à Análise Documentárias e às Linguagens Documentárias, uma vez que são temas ilustrativos e fundamentais para a organização da informação.

Dessa forma, o trabalho apresenta inicialmente uma discussão introdutória sobre Organização da Informação e Organização do Conhecimento, em seguida contextualiza a Análise Documentária e as Linguagens Documentárias, para dar sequência com a análise empírica da pesquisa e produção científica na Ciência da Informação. 


\section{Questões introdutórias sobre a precisão conceitual na Organização da Informação e Organização do Conhecimento}

A precisão conceitual, em qualquer área e também na Ciência da Informação, tem como uma de suas finalidades permitir a comunicação científica precisa, ou seja, garantir troca efetiva de informação entre os pares sem a confusão dos conceitos empregados e representados por meio dos termos.

Diante disso, para podermos falar de Organização da Informação e de Organização do Conhecimento é preciso, antes, retomar a diferenciação entre informação e conhecimento adotada na Ciência da Informação. A discussão sobre "o que é informação?" e "o que é conhecimento?" no contexto da Ciência da Informação é recorrente da área (ROBREDO, 2003; LE COADIC, 2004; CAPURRO; HJORLAND, 2007) e não pretendemos eleger uma definição para os termos, mas sim mostrar como a discussão sobre o assunto é produtiva. Assim, procura-se evidenciar alguns aspectos de fundamentação teórica da área de Ciência da Informação.

Para uma proposta de compreensão dos termos que compõem o léxico de uma área de conhecimento é preciso fazer a análise desses termos, segundo Brascher e Café (2008), considerando: a) relacionar seus conceitos às funções que damos a eles nos contextos em que se inserem; b) diferenciá-los de conceitos próximos a eles e incluídos no sistema referencial.

Para iniciar a exposição sobre o entendimento de informação e conhecimento na Ciência da Informação, é preciso destacar que, muitas vezes, suas definições são apresentadas conjuntamente, ora trazendo visões de oposição, ora de decorrência, ora de complementação e de outras relações possíveis (SILVA, 2003). Além do que, estarão, invariavelmente, associadas à ideia de comunicação, com a tríade emissor/receptor/mensagem e também com a ideia de cognição, pode ser verificado em Robredo (2003) e Capurro e Hjorland (2007). 
Utilizando algumas dessas formas de exposição de ideias, Fernandez-Molina (1994, p. 328 apud BRASCHER; CAFÉ, 2008, p. 2), diz que:

[...] os dados são informação potencial, que somente são percebidos por um receptor se forem convertidos em informação e esta passa a converter-se em conhecimento no momento em que produz uma modificação na estrutura do conhecimento do receptor.

A ideia de conversão presente na passagem da informação para o conhecimento pode ser entendida como um processo cognitivo, em que a informação funcionaria como insumo para o conhecimento. Outra ideia presente na definição de Fernandez-Molina é a de que o conhecimento é dinâmico, em constante estado de transformação.

Além das tradicionais formas de apresentação do que vem a ser informação e conhecimento, há também as analogias, como a utilizada por Peter Burke. O autor aproxima a informação a algo "cru" e o conhecimento a algo "cozido". A informação, o cru, segundo Burke (2003), se refere a algo específico e prático, enquanto o conhecimento, "o cozido", seria o resultado do processo ou sistematização do pensamento.

Mais uma vez temos o entendimento de informação como insumo para o conhecimento, uma vez que "o cozido" necessariamente foi "cru" em um determinado momento e o "calor" que promove esse cozimento é o processo cognitivo, ou seja, o pensamento.

Outra visão de informação é apresentada, como mencionado, por Fernando Capurro e Birger Hjorland. Em uma perspectiva pragmática, dizem que o conceito de informação está diretamente relacionado ao que se deseja ser respondido, ou seja, a partir dessa visão a informação tem a função de responder a uma questão ou problema, o que a limita dentro de um determinado contexto ou realidade de uso (CAPURRO; HJORLAND, 2003).

Em outras palavras, como afirmam Brascher e Café (2008), em um sistema de informação, o valor da informação depende do significado particular 
atribuído a ela pelo receptor desta informação, uma vez que ele a adota segundo um determinado propósito.

Fogl apresenta visões sobre os conceitos de informação e de conhecimento, assim sistematizadas por Brascher e Café:

1) Conhecimento é o resultado da cognição (processo de reflexão das leis e das propriedades de objetos e fenômenos da realidade objetiva na consciência humana);

2) Conhecimento é o conteúdo ideal da consciência humana;

3) Informação é uma forma material da existência do conhecimento;

4) Informação é um item definitivo do conhecimento expresso por meio da linguagem natural ou outros sistemas de signos percebidos pelos órgãos e sentidos;

5) Informação existe e exerce sua função social por meio de um suporte físico;

6) Informação existe objetivamente fora da consciência individual e independente. (FOGL, 1979 apud BRASCHER; CAFÉ, 2008, p. 4)

Como visto até o momento, é possível dizer que informação e conhecimento são conceitos fundamentais para a compreensão da Ciência da Informação, e que se apresentam como diferentes, ainda que relacionados ou decorrentes dentro do processo de conhecimento e cognição. Isso faz com que também se indique uma distinção no que vem a ser Organização da Informação e Organização do Conhecimento. 


\section{Organização da Informação e Organização do Conhecimento}

$\mathrm{Na}$ Ciência da Informação, os sistemas de organização do conhecimento têm, de acordo com Carlan (2010, p. 134), um percurso teórico comum quanto à construção de taxonomias, ontologias, tesauros e sistemas de classificação. No âmbito das representações da Organização do Conhecimento, temos os Sistemas de Organização do Conhecimento (SOC), que são sistemas conceituais que representam um domínio por meio da sistematização dos conceitos e das relações semânticas que se estabelecem entre eles. O termo Knowledge Organization Systems foi proposto e empregado pela primeira vez, segundo Brascher e Café (2008, p. 8), pelo Networked Knowledge Organization Systens Group, em 1998, "[...] para englobar sistemas de classificação, cabeçalhos de assunto, arquivos de autoridade, redes semânticas e ontologias."

Com o passar dos anos e as reflexões sobre o tema, outros sistemas foram sendo incorporados ao que se entende por Sistemas de Organização do Conhecimento, como os dicionários, glossários, taxonomias e tesauros.

Baseando-se em Soergel (1999), Brascher e Café (2008, p. 8), dizem que, entre os objetivos dos Sistemas de Organização do Conhecimento, estão:

[...] prover uma mapa semântico para domínios individuais e para os relacionamentos entre domínios, fornecendo orientação e servindo como um instrumento de referência; melhorar a comunicação e o ensino; prover uma base conceitual para a boa execução da pesquisa e implementação; prover classificação para a ação, isto é, o uso prático dos SOC em diferentes atividades profissionais, tais como a classificação de doenças para diagnósticos médicos e de mercadorias para o comércio; apoiar a recuperação da informação; prover uma base conceitual para sistemas baseados em conhecimento e para a definição de elementos de dados e hierarquias de objetos na engenharia de software, servir como um dicionário mono, bi ou multilíngue para uso pelo homem ou por sistemas automáticos de processamento da linguagem natural. 
Nesse contexto, para que se tenha um panorama inicial das possibilidades de definições de Organização da Informação e Organização do Conhecimento em Ciência da Informação é preciso recorrer a alguns autores, sem a perspectiva de esgotar as variáveis de entendimento e de autores que se debruçaram sobre o assunto.

Sendo assim, Brascher e Café (2008, p. 5, grifo do autor) dizem que:

A organização da informação é, portanto, um processo que envolve a descrição física e de conteúdo dos objetos informacionais. O produto desse processo descritivo é a representação da informação, entendida como um conjunto de elementos descritivos que representam os atributos de um objeto informacional específico. Alguns tipos de representação da informação são construídos por meio de linguagens elaboradas especificamente para os objetivos da Ol. Essas linguagens, segundo Svenonius (2000) subdividem-se em linguagens que descrevem a informação e linguagens que descrevem o documento (suporte físico).

$\mathrm{Na}$ definição das autoras está presente o conceito de representação da informação como um produto do processo de organização da informação, ou seja, como o meio para se alcançar seus os objetivos. Logo, nessa definição, a organização da informação pode se caracterizar como um processo, e a representação da informação, como um produto.

É interessante notar que a Organização da Informação é apresentada como um processo de descrição física e de conteúdo dos objetos informacionais. Portanto, pode-se dizer que para Brascher e Café, a Organização da Informação se debruça sobre o "mundo dos objetos físicos". A essa definição, é possível acrescentar a ideia de objeto informacional, que aparece na citação acima. Essa definição advém da ideia de "information package", empregada por Taylor (2004) em The Organization of Information, onde defemde que os objetos informacionais compreendem diversos tipos de informação registrada e em diferentes suportes. 
Nesse sentido, a definição de Organização da Informação fica melhor caracterizada quanto vista em paralelo com a definição de Organização do Conhecimento:

No contexto da Ol e da RI, temos como objeto os registros de informação. Estamos, portanto, no mundo dos objetos físicos, distinto do mundo da cognição, ou das ideias, cuja unidade elementar é o conceito. A cognição, como afirma Fogl (1979, p.22), 'é o processo de reflexão das leis e das propriedades de objetos e fenômenos da realidade objetiva na consciência humana'. Ainda segundo o autor, o resultado da cognição é o conhecimento e não a informação. Quando nos referimos à OC e à $\mathrm{RC}$, estamos no mundo dos conceitos e não naquele dos registros de informação. (BRASCHER; CAFÉ, 2008, p. 5-6)

Sendo assim, para Brascher e Café, Organização da Informação e Organização do Conhecimento diferem quanto aos seus objetos, que respectivamente são apontados como sendo o mundo dos objetos físicos e o mundo da cognição, cujo produto é o conhecimento. No entanto, é possível notar outras interpretações presentes na literatura da área de Ciência da Informação.

Dessa forma, ao se elaborar resumos, classificações e indexação também se estaria, de alguma maneira, entrando em contato com os conceitos presentes nos documentos e, portanto, já atuando no campo da Organização do Conhecimento e, não mais, no campo da Organização da Informação.

Segundo Brascher e Café, ainda assim, esses processos estariam sobre a égide da Organização da Informação, pois atuam com os conceitos contidos no objeto informacional, se restringindo, ao que acreditam ser, a visão particular autor. E que a Organização do Conhecimento, traria uma visão mais ampla dos conceitos, como aqueles inseridos em um domínio particular e com uma finalidade determinada:

No primeiro caso, temos uma representação conceitual individual, relativa a um objeto informacional em particular, na qual a escolha dos elementos de representação leva em conta a maneira com o autor expõe as ideias no texto, bem como as necessidades informacionais dos usuários potenciais de um sistema de informação. No caso da representação do conhecimento, a representação construída não se restringe ao 
conhecimento expresso por um autor, ela é fruto de um processo de análise de domínio e procura refletir uma visão consensual sobre a realidade que se pretende representar. A representação do conhecimento reflete um modelo de abstração do mundo real, construído para determinada finalidade. (BRASCHER; CAFÉ, 2008, p. 6)

A ideia de Organização do Conhecimento e Representação do Conhecimento com formas de representação conceitual de domínios é explicitada na seguinte afirmação:

Delineamos a OC como o processo de modelagem do conhecimento que visa a construção de representações do conhecimento. Esse processo tem por base a análise do conceito de suas características para o estabelecimento da posição que cada conceito ocupa num determinado domínio, bem como das suas relações com os demais conceitos que compõem esse sistema nocional. (BRASCHER; CAFÉ, 2008, p.8)

Outros autores também localizam no conceito o item fundamental para definir Organização do Conhecimento. Dahlberg (1993) afirma que a Organização do Conhecimento tem como base as unidades de conhecimento e que, por sua vez, são os próprios conceitos. Nesse mesmo contexto, ao caracterizar a Organização do Conhecimento, Dahberg diz que está é a ciência que estrutura e organiza sistematicamente unidades do conhecimento (conceitos) segundo seus elementos de conhecimento (características) inerentes e a aplicação desses conceitos e classes de conceitos ordenados a objetos/assuntos.

Considerados assim, Organização da Informação e Organização do Conhecimento, contam com representações também diferentes:

Esses dois processos produzem, consequentemente, dois tipos distintos de representação: a representação da informação, compreendida como o conjunto de atributos que representa determinado objeto informacional e que é obtido pelos processos de descrição física e de conteúdo, e a representação do conhecimento, que se constitui numa estrutura conceitual que representa modelos de mundo, os quais, segundo Le Moigne (apud CAMPOS, 2004, p.23), permitem descrever e fornecer explicações sobre os fenômenos que observamos. (BRASCHER; CAFÉ, 2008, p. 6) 
Pelo levantamento efetuado e com a apresentação de algumas definições sobre Organização da Informação e Organização do Conhecimento, é possível falarmos em diferenciações, proximidades e sobreposições no entendimento de ambas, tornando a pesquisa sobre o uso desses termos para indexação dos trabalhos na área de Ciência da Informação como algo a contribuir para compreensão/definição dos mesmos.

Considerando a perspectiva pragmática do que vem a ser informação, como o exposto por Capurro e Hjorland, e trazendo essa perspectiva para a compreensão da Organização da Informação, pode-se dizer que é necessário considerar o aspecto pragmático, pois, a qualidade do conteúdo da informação é definida pelos processos de cognição e avaliação efetuados pelo receptor/usuário, de forma que a informação não é um mero objeto material, mas deve ser, como disse Fogl (1979 apud BRASCHER; CAFÉ, 2008), entendida como o resultado de atividade cognitiva e avaliativa.

O que se pergunta, no contexto da Organização da Informação e da Organização do Conhecimento, é como fica a questão da documentação. A seguir, se tentará fazer essa análise, buscando o contexto da Análise Documentária. 


\section{Análise Documentária: a configuração teórica do campo de conhecimento}

É atribuída a Jean-Claude Gardin a criação do termo Análise Documentária para a denominação do campo de estudo que se pretende apresentar. Ainda a Gardin é atribuída a criação da fundamentação teórica e a terminologia adotada pela Documentação de orientação francesa e de certas vertentes anglo-saxônicas (KOBASHI, 1994, p.32). Como se verá, essa bagagem conceitual de Gardin em outras áreas irá compor grande parte do que vem a ser a Análise Documentária.

Portanto, para entender o escopo de atuação da Análise Documentária e sua fundamentação teórica iremos partir de uma definição que balizará toda a exposição do tema e suas discussões. A literatura especializada da área apresenta várias definições para Análise Documentária, todas muito próximas, dentre as quais destaca-se:
A Análise Documentária ( $A D)$ é a expressão usada para designar o conjunto de procedimentos efetuados com a finalidade de expressar o conteúdo dos documentos científicos sob formas destinadas a facilitar a recuperação da informação. (GARDIN apud CUNHA, 1989, p.17)

A acima citada definição de Análise Documentária feita por JeanClaude Gardin traz aspectos fundamentais para compreensão do tema. Os referidos aspectos, além de básicos, são apresentados de forma encadeada, evidenciando objetivos, método e forma. A partir do que foi afirmado por Gardin, a Análise Documentária seria o conjuntos de procedimentos com a finalidade de expressar o conteúdo de documentos científicos por meio de formas que facilitem a recuperação da informação.

A partir da definição de Gardin sobre Análise Documentária, esta pode ser vista como procedimentos documentários, efetuados sobre 
documentos que geram produtos documentários para recuperação de informação.

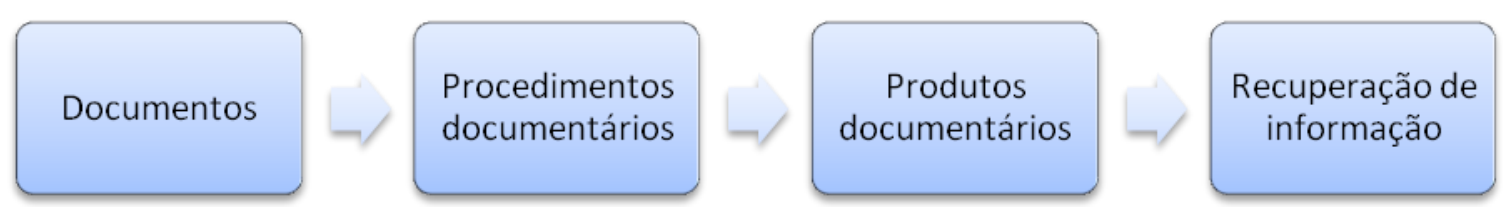

Figura 1 - Esquema simplificado da àrea de atuação da Análise Documentária (Baseado na definição de Gardin (GARDIN apud CUNHA, 1989, p.17)

Dentro de uma perspectiva de definição teórica de Análise Documentária, a definição apresentada por Gardin traz dois elementos importantes para seu entendimento, o processual e o procedimental.

No que se refere aos aspectos processuais, entende-se a inserção de todas as atividades da Análise Documentária dentro de um processo comunicativo, onde se encontram, em um extremo, as informações registradas em documentos (emissor) e, no extremo oposto, as informações recuperadas por um usuário (receptor). Por sua vez, os aspectos procedimentais são aqueles que compõem as etapas de ligação dos dois extremos do processo comunicativo.

A inserção das atividades da Análise Documentária em uma visão processual também está presente na literatura da área como fluxo documentário (KOBASHI, 1994, p. 21). O uso da denominação fluxo documentário é um indicativo de que o foco, naquele momento, estava no documento e nas etapas de tratamento pelas quais ele era submetido até a sua recuperação.

Neste ponto, percebe-se a influência da Documentação e da Biblioteconomia tradicional nas práticas da Análise Documentária. Ainda que houvesse a compreensão de que todo o processo de tratamento do documento 
visasse a sua recuperação pelo usuário, o foco ainda era as etapas procedimentais do processo comunicativo.

As ampliações efetivas da perspectiva comunicativa do processo de organização e representação do conhecimento e da informação ganham força através das discussões sobre significação nos estudos dos instrumentos de representação. Em outras palavras, foram os estudos dos aspectos procedimentais, de criação de linguagens de representação, que evidenciaram a inserção dessas etapas em um processo comunicativo.

A ampliação de perspectiva, que passa do tratamento do conteúdo do documento para a informação a ser recuperada e comunicada, faz com que seja inevitável a compreensão das atividades da Análise Documentária como parte integrante de um processo comunicativo.

Conceitualmente, trata-se de uma ampliação de perspectiva já presente na área, no entanto, isso acaba por agregar as discussões de Análise Documentária aos elementos teóricos de áreas como a Comunicação e a Linguística, consolidando a Análise Documentária como uma área interdisciplinar de estudos e expandindo as bases teóricas de suas práticas.

Apesar de haver exemplos de práticas de tratamentos documentários muito antigas, essas não eram sistematizadas e dependiam do bom senso de seu executor.

Até há muito pouco tempo, os métodos desta análise foram considerados como operações empíricas de 'bom senso' pelas quais se atribuía, a um texto/documento qualquer, uma ou várias palavras-chave destinadas a facilitar a recuperação, no momento da pesquisa, sob um dado tema. À leitura, realizada dos textos/documentos com fins de análise documentária, a Biblioteconomia/Documentação atribui, implícita ou explicitamente, uma leitura única, fechada e universal, independente do leitor/analista da documentação. O mesmo tipo de preconceito surge com a atribuição de palavras-chave aos textos/documentos, na medida em que se consideram as palavras 'neutras', desprovidas de sentidos. (CUNHA, 1989, p.61) 
A sistematização das práticas de análise documentária é tardia, tendo seu princípio com a Documentação e sua consolidação a partir da introdução dos recursos computacionais no fazer documentário no final dos anos 1950 e início dos anos 1960.

\begin{abstract}
A análise documentária foi, durante muito tempo, feita em bases empíricas sem uma sistematização mais rigorosa de seus procedimentos. As necessidades de recuperação de informação em níveis cada vez mais refinados, a realização dessas atividades em bases industriais e o consequente uso de sistemas automatizados, passam a exigir maior rigor na representação e estruturação de conteúdos de documentos. (CUNHA; KOBASHI; AMARO, 1987, p. 114)
\end{abstract}

A busca pela criação de metodologias para as práticas de Análise Documentária visa à elaboração de produtos documentários com maior rigor e de melhor qualidade. E, se na década de 1980, a elaboração de metodologias para análise documentária era incipiente (SMIT, 1987), é possível dizer que hoje existem metodologias bem consolidadas, como as normas nacionais e internacionais que versam sobre elaboração de produtos documentários.

Mais especificamente, os aspectos procedimentais dizem respeito aos procedimentos adotados pela área para a elaboração de produtos documentários que visam à recuperação da informação. Esses são basicamente seleção de documentos, leitura documentária, análise de conteúdo ou síntese de conteúdo e representação da informação documentária, em resumos ou índices.

O procedimento de representação para elaboração de índices, muitas vezes, é chamado de tradução, entendido como a passagem da linguagem presente no documento para a linguagem documentária. Com a adoção do termo tradução para designar a atividade feita de representação da informação presente no documento em um termo na linguagem de representação tem-se, novamente, a influência dos estudos de significação das palavras e dos termos. A essa concepção foram feitas críticas que versam sobre a dificuldade de se propor uma tradução direta da linguagem do documento para a linguagem de 
representação, uma vez que, nesse processo, estão inseridos aspectos de significação e interpretação presentes nas linguagens e agentes envolvidos.

\subsection{Vertentes teóricas de fundamentação da Análise Documentária}

Segundo Cunha, Kobashi e Amaro (1987, p. 114), existem duas vertentes de fundamentação teórica para a Análise Documentária ${ }^{1}$, uma que privilegia os métodos de ocorrência/frequência, ou seja, métodos quantitativos, e uma segunda vertente que adota os métodos de base lógico-semântica.

Essas duas vertentes teóricas da Análise Documentária podem ser localizadas geograficamente, tendo respectivamente como pólos irradiadores: os Estados Unidos e a Inglaterra de um lado e, de outro, a França.

A vertente que privilegia os métodos de ocorrência/frequência e, consequentemente, foca seus estudos no desenvolvimento de instrumentos, tem sua origem nos Estados Unidos e na Inglaterra. Enquanto que a vertente que privilegia os métodos de base lógico-semântica e se preocupa com 0 desenvolvimento de referencial teórico para área, tem sua origem na França (GUIMARÃES, 2008, p.81), tendo Gardin como seu maior expoente.

A Espanha e o Brasil, ao aderirem à vertente francesa, contribuíram para a consolidação da Análise Documentária como um segmento específico dentro da Ciência da Informação. No contexto brasileiro, destacam-se as contribuições geradas a partir dos estudos desenvolvidos pelo grupo TEMMA².

\footnotetext{
${ }^{1}$ Essa separação esquemática das vertentes que compõem a Análise Documentária reflete em grande parte a realidade apresentada pela área, mas também é de caráter operacional, visando a compreensão de suas vertentes, tendo sempre em vista suas nuances internas e trocas conceituais.

2 Grupo TEMMA se formou em 1986, dentro do Departamento de Biblioteconomia e Documentação - ECA/USP. No início de suas atividades o grupo concentrou seus esforços nas reflexões teóricas e práticas da Análise Documentária, enfatizando os procedimentos que subjazem à atividade da representação do conteúdo. Hoje o grupo atua na construção de conhecimentos relacionados à organização da informação.
} 


\subsection{A configuração interdisciplinar da Análise Documentária}

$\mathrm{Na}$ vertente francesa de fundamentação teórica da Análise Documentária é evidenciada a formação interdisciplinar da área, que conta com contribuições da Linguística, da Lógica e da Filosofia da Linguagem (SMIT, 1987, p. 114), mais as contribuições teóricas advindas da Terminologia e da Psicolinguística. Contando, ainda, com aproximações em diferentes graus com as análises de conteúdo, literária, semióticas e linguísticas (CUNHA, 1990, p. $62)$.

Dentre os trabalhos que apresentam a Análise Documentária no contexto nacional, destaca-se a obra "Análise Documentária - análise da síntese" (CUNHA; KOBASHI; AMARO, 1987). Esse trabalho conta com um capítulo de revisão bibliográfica, em que se analisam os principais autores e obras que fundamentam a Análise Documentária, a partir da base lógicosemântica, da vertente francesa.

As principais contribuições dos autores de Linguística Geral para a Análise Documentária, segundo Cunha, Kobashi e Amaro, são as questões relacionadas à língua/fala, significado/significante/signo, as relações sintagmáticas e paradigmáticas, a noção de "caso", Teoria das modalidades, os estudos de semântica, os procedimentos e métodos para análise de textos/documentos, elaboração de glossários e vocabulários controlados, implicações da passagem da linguagem natural para linguagem documentária, entre outras.

Dentre as contribuições dos estudos de Linguística Geral, destacamse as discussões sobre significado, significante e signo. Essas contribuições interferem diretamente nas práticas de análise documentária, possibilitando um conhecimento teórico sobre a constituição das palavras enquanto produtos da representação do significado, do significante e do signo. A compreensão da constituição significativa da palavra é estendida para compreensão dos textos/documentos/informações, novamente evidenciando os aspectos comunicativos que compõem a prática da Análise Documentária. 
Quadro 1 - Contribuições interdisciplinares para Análise Documentária segundo área de conhecimento de autores

\begin{tabular}{|c|c|c|c|}
\hline & \multicolumn{3}{|c|}{ Áreas de conhecimento } \\
\hline & Linguística Geral & $\begin{array}{c}\text { Lógica/ } \\
\text { Filosofia da Linguagem }\end{array}$ & $\begin{array}{c}\text { Linguística e } \\
\text { Documentação }\end{array}$ \\
\hline \multirow{5}{*}{$\frac{\mathscr{U}}{\stackrel{\Xi}{0}}$} & Saussure & Apel & Gardin \\
\hline & Pottier & Pescador & Smit \\
\hline & Fillmore & Bronckart & Cintra \\
\hline & Greimas & Pecheux & Cattenat \\
\hline & Lyons & & Paul \\
\hline
\end{tabular}

Fonte: Baseado em levantamento realizado por Cunha, Kobashi e Amaro (1987).

A partir dessas contribuições, a Análise Documentária pode aprimorar o conhecimento teórico sobre seu objeto texto/documentos/informações, o que levou à maior compreensão, e também revisão, de seus procedimentos e métodos de abordagem do objeto informação nas etapas de leitura, seleção e tradução.

No âmbito da Lógica e Filosofia da Linguagem, as contribuições apontadas contemplam as discussões sobre a relação conhecimento/pensamento/linguagem, a abordagem cognitiva das Ciências, a interferência da ideologia na linguagem e a análise do discurso, a partir de considerações sociais.

As contribuições com maiores desdobramentos para a Análise Documentária foram a análise de discurso e de conteúdo, que abriram novas 
perspectivas para os processos de automação das práticas de tratamento de conteúdos documentários.

Já em relação aos autores do grupo Linguística/Documentação, as contribuições teóricas são mais diretas, devido à proximidade entre a Análise Documentária e a Documentação. Essas contribuições, de maneira geral, dizem respeito à análise objetiva do texto/documento, com considerações sobre as relações interdisciplinares, os recortes, métodos e procedimentos para o tratamento do documento e recuperação da informação.

A configuração interdisciplinar da formação teórica da Análise Documentária suscita alguns questionamentos sobre a forma de incorporação das contribuições de outras áreas.

Este envolvimento de caráter interdisciplinar preconizado na opção da matriz teórica inicial - os trabalhos de J.C. Gardin comporta riscos de imprecisões e incoerência não só relativos às teorias 'truncadas' mas também ao problema da incompatibilidade, apenas possível de resoluções através de testes e experiências que permitam determinar e sancionar com alguma margem de segurança as opções e adequações realizadas. (CUNHA, 1989, p. 18)

A preocupação trazida por Cunha é pertinente às discussões de formação teórica da Análise Documentária, no entanto, a configuração que o campo tomou após 60 anos de discussão sobre sua constituição enquanto segmento específico dentro da Ciência da Informação, pautada em fazeres específicos, faz com que se acredite que os limites entre as outras disciplinas e a Análise Documentária já estejam estabelecidos. Na bibliografia da área, a relação entre as diversas disciplinas que se associam às discussões presentes, também na Análise Documentária, é apontada como relações de contribuição, onde não há confusão ou sobreposição de campo de estudo. 
4. A fundamentação teórica dos processos de organização e representação do conhecimento e da informação e as contribuições da Análise Documentária

Dentro da discussão proposta para tentar delimitar e compreender a fundamentação teórica dos processos de organização e representação do conhecimento e da informação, o levantamento sobre a formação teórica da Análise Documentária traz algumas contribuições.

A primeira das contribuições é a inserção dos processos de organização e representação e, por sua vez, das atividades de análise documentária, dentro de um processo comunicativo. Ou seja, toda a proposta de organização e representação do conhecimento e da informação visa à comunicação. Ainda que as etapas procedimentais (fluxo documentário), que criam o caminho para a comunicação, ocupem grande parte da atenção dos trabalhos em Análise Documentária, é a dimensão processual, da comunicação, que determina a finalidade das suas etapas: facilitar a comunicação entre a informação registrada e a recuperação e apropriação da informação pelo usuário.

Outra contribuição a ser explorada é a relação ideologia-linguagem, que aparece nas contribuições dos estudos de Linguística. A dificuldade de se trabalhar a interferência da ideologia na linguagem, talvez, seja a causa da pouca atenção dada ao tema dentro da Análise Documentária. Ainda que essa seja uma tarefa difícil, a compreensão da relação entre ideologia-linguagem é imprescindível para entender as bases do processo de organização e representação da informação, pois esses são processos intencionais que fazem uso da linguagem para transmitir a mensagem a ser comunicada.

Ainda que os procedimentos de tratamento da informação visem à tradução e à fidedignidade dos documentos de referência, sabe-se que aspectos de interpretação compõem esse processo comunicativo. 
A abordagem cognitiva da ciência e a abordagem social da análise do discurso, que contribuíram para a Análise Documentária, também contribuem para a ampliação do que constitui as bases de fundamentação teórica dos processos de organização e representação do conhecimento e da informação. Essas abordagens trazem para a discussão os aspectos sociais e cognitivos que compõem as atividades humanas intencionais, dentre as quais estão a comunicação e, consequentemente, os processos de organização e representação da informação.

As três contribuições, acima citadas, já indicam a viabilidade da compreensão dos processos de organização e representação do conhecimento e da informação como formas, também, de interpretações intencionais.

\subsection{Linguagem documentária: trajetória teórica, procedimentos de elaboração e utilização}

Tomando-se a Análise Documentária como embasamento para a busca das bases teóricas de fundamentação dos processos de organização e representação do conhecimento e da informação, encontramos os instrumentos de representação de conteúdos como partes fundamentais desse processo, dentre os quais, destacaremos as Linguagens Documentárias.

A importância das Linguagens Documentárias para a compreensão da Análise Documentária e dos processos de organização e representação é tão significativa que é difícil encontrar uma definição de Análise Documentária que não faça referência ao uso desses instrumentos.

El análisis documental consiste en extraer las ideas centrales de un documento con el fin de disponerlo para su recuperación mediante representaciones sintéticas, a través de una desestructuración semática de un fragmento de discurso de tal manera que las piezas resultantes puedan reconstruir potencialmente el mismo fragmento a la vez que lo conectan com el discurso general que se halla inserto. El processo 
desestructuración/estructuración interviene un instrumento conmutador y referencial del sistema y la norma, denominado lenguaje documental. (GARCIA GUTIÉRREZ, 1990, p.49, grifo nosso)

Assim como existem várias definições para Análise Documentária, o mesmo ocorre com para as Linguagens Documentárias. Porém, o que se nota nessas definições, é que são praticamente formas diferentes de dizer a mesma coisa, com algumas exceções.

Muitas são as definições de Linguagem Documentária encontradas na literatura da Documentação. Embora exista variação, há concordância sobre sua função primordial: funcionar como instrumento para a representação e a recuperação da informação. As maiores diferenças são relativas às designações que, por seu turno, correspondem ao entendimento do instrumento de representação: seguindo o modelo europeu, desde Gardin, Linguagem Documentária (language documentaire) é o termo mais adotado; linguagem de indexação (indexing language), segundo 0 modelo americano. (LARA, 2009, p.45)

Como é possível notar, a partir das considerações de Lara, a divisão entre as duas vertentes, a europeia e a americana, presente na conformação teórica da Análise Documentária, também se mantêm quando o assunto são as Linguagens Documentárias.

As Linguagens Documentárias interessam na medida em que são utilizadas nos processos de organização e representação da informação, na etapa de passagem da linguagem do documento para a linguagem de representação. As Linguagens Documentárias são produtos tangíveis das atividades de análise documentária e são elaboradas com o fim único de mediar o, já referido, processo comunicativo. Devido a essa natureza das Linguagens Documentárias, acredita-se que elas são fontes para a compreensão das bases teóricas do processo de organização da informação.

Em uma visão retrospectiva da área, é possível dizer que devido à herança da Documentação, com sua ancoragem em pressupostos positivistas, existiu e, talvez ainda exista na área, a compreensão das Linguagens 
Documentárias como formas de representação sintética direta dos conteúdos dos documentos. Essa visão diminui a dimensão teórica de elaboração e aplicação das linguagens documentárias, reduzindo-as a meros instrumentos operacionais.

Como foi visto anteriormente, com as contribuições teóricas da Linguística, da Lógica e, sobretudo, dos trabalhos de Semântica, é possível afirmar que essa abordagem incorre no erro de acreditar que a representação feita com o uso de uma Linguagem Documentária seja direta, permitindo espelhamento reduzido do documento.

Para Barreto (1994) uma vez que o conteúdo não é algo perfeitamente identificado, mas resultado de uma escolha institucional, a representação deve ser compreendida como construção, "organização em si", que é oferecida para interpretação.

A ideia de construção das Linguagens Documentárias, a partir de escolhas quer sejam institucionais, sociais, ou até mesmo pessoais, faz com que essa construção venha a ter o caráter principal de interpretação. Ainda que se concorde com a afirmação de Barreto, de que as Linguagens Documentárias e seus produtos são oferecidos para a interpretação do usuário, acredita-se que os mesmos constituem em si formas de interpretações intencionais.

Segundo Lara (2009, p. 48), a Linguagem Documentária se coloca como uma possibilidade interpretativa. Essa possibilidade interpretativa teria os seus limites pautados pelos documentos e pela sua área de domínio.

Dito de outro modo, ela pode desencadear interpretantes que, no discurso científico e técnico, mais do que mobilizar referências individuais, trazem à tona referências compartilhadas pela comunidade discursiva a que corresponde. A Linguagem Documentária, assim, apresenta-se como uma espécie de combinatória (no sentido de Greimas) que pretende possibilidades de interação, combinando referenciais da área de conteúdo foco e referências dos usuários. Disso resulta uma 
hipótese de organização que formalizada, concretiza vínculos de significação. (LARA, 2009, p.49)

Nesta colocação de Lara, a comunidade discursiva ocupa o papel de elemento aglutinador para atribuição de significado a ser adotado pela linguagem de representação. A concepção de comunidade discursiva atende a uma abordagem sócio-cognitiva da Ciência da Informação, e que contribui significativamente para o entendimento dos processos de organização de informação como formas de interpretação e, portanto, carregadas de ideologia.

Um aspecto corrente na literatura da área em relação às Linguagens Documentárias é o papel normalizador que ela desenvolve no processo de recuperação de informação. Esse papel normalizador não deve ser encarado como sendo neutro. Para Gil Urdiciain (2004) as linguagens documentárias são consideradas um sistema artificial de signos normalizados que facilitam a representação formalizada do conteúdo dos documentos. A partir dessa contribuição de Gil Urdiciain, o aspecto a ser desenvolvido é a ideia das Linguagens Documentárias enquanto articuladoras de signos.

Lara e Ortega (2011), ao abordarem o documento dentro da Ciência da Informação, fazem considerações objetivas sobre o caráter de signo que a Linguagem Documentária carrega.

Todas as descrições desse documento - signo - compõem o que podemos denominar signo documentário, que corresponde, entre outros, ao documento secundário, conforme proposta de Briet. Esse signo documentário, todavia, não apresenta todas as possibilidades de desenvolvimento semiótico do signo de um modo geral, o que decorre não somente do caráter construído da linguagem documentária usada para representá-lo (outro signo), como também das regras para sua descrição formal. Dito de outra forma, o signo documentário é construído sob pressão, seguindo regras que buscam reduzir a dispersão documental. A referência de construção desse signo corresponde àquilo que se deseja configurar como sistema documentário. Isso explica que um mesmo acervo possa ser representado de diferentes maneiras. (LARA; ORTEGA, 2012, p. 34) 
O entendimento das Linguagens Documentárias, enquanto signo documentário, é uma contribuição dos estudos de Linguística e Semântica. Esse entendimento também traz para as discussões questões referentes à ideologia e à linguagem, como indicam Cunha, Kobashi e Amaro (1987), ao apontarem as contribuições de José Hierro S. Pescador, em seu livro Princípios de Filosofia del Lenguage, para a área de Biblioteconomia/Documentação e herdadas pela Análise Documentária.

Discute a viabilidade de uma teoria completa e unitária do significado e da interferência da ideologia na linguagem.

Em Biblioteconomia/Documentação ambas as questões são problemáticas na medida em que analisamos textos/documentos e os traduzimos em conceitos/palavraschave, isto é buscamos significados. Nestes reflete-se o problema da transferência da ideologia da linguagem natural, especializada e documentária. (CUNHA; KOBASHI; AMARO, 1987, p.124)

Apesar de todo o esforço de teorização da Análise Documentária e da normatização de seus procedimentos e instrumentos, dentre eles as Linguagens Documentárias, existem variáveis que interferem no processo documentário.

No entanto, mesmo trabalhando de uma forma empíricopragmática o analista da documentação tem de ter em conta algumas variáveis, notadamente, as do discurso (com pretensões científicas ou não) realizadas através de uma língua dada e que compreende a sua organização interna, a sua linguagem e ideologia. Estas variáveis surgem não só na fase de análise, procedimento, como na obtenção do produto documentário. Nesta última, é necessário ter em conta o sistema em que se encontra inserida a disseminação desse produto-informação e a variável produtor-tradutor-consumidor da mesma, sendo que a estas é inerente a existência de uma linguagem e ideologia refletora do pensamento e da situação em que se encontram inseridas (CUNHA, 1990, p.60, grifo nosso)

A partir dessa consideração pode-se dizer que, independentemente do nível de embasamento teórico que a Análise Documentária alcance, seu objeto - os documentos -, seus instrumentos - entre eles as Linguagens Documentárias - e seus produtos, operam necessariamente com discursos e criam/reproduzem outros discursos. Sendo assim, a Análise Documentária 
estará sujeita a influência do contexto social, chamado por Cunha (1990), de ideologia.

Longe de se esgotar as possibilidades de abordagem referente à fundamentação teórica das Linguagens Documentárias, já é possível notar algumas contribuições para compreensão da fundamentação teórica dos processos de organização e representação do conhecimento e da informação.

Destaca-se, nesse momento, a concepção das Linguagens Documentárias como signos interpretativos criados a partir dos parâmetros de uma comunidade discursiva. Essa definição afasta qualquer concepção que atribua às Linguagens Documentárias um papel neutro de mero instrumento, apontando assim que os processos de organização e representação são carregados de intencionalidade, interpretação e ideologia.

Como se verá a seguir, essa perspectiva é corroborada e acrescida de embasamento teórico a partir das discussões sobre o paradigma sóciocognitivo na Ciência da Informação.

\subsection{Contribuições do paradigma sócio-cognitivo para a} compreensão dos processos de organização e recuperação da informação

Ao abordar os processos de organização e representação do conhecimento e da informação sob o escopo da Análise Documentária, tornase necessário tratar dos paradigmas epistemológicos da grande área, Ciência da Informação. Para tratar dos paradigmas epistemológicos da Ciência da Informação, Capurro (2003) afirma ser primordial retomar a ideia da construção social dos processos informativos. 
Considerando que os processos informativos são construções sociais, essa característica pode ser estendida para os processos comunicativos e também para as práticas de organização e representação da informação como o demonstrado pela Análise Documentária.

Dentre as possíveis contribuições dos paradigmas da Ciência da Informação para o desenvolvimento da presente pesquisa, o paradigma social traz o conceito de comunidade discursiva, grupos sociais e de trabalho como unidades de análise (HJORLAND apud CAPURRO, 2003). A partir do conceito de comunidades discursivas como parâmetro de unidades de análise para os processos de organização e recuperação da informação, cria-se o entendimento da impossibilidade de uma linguagem ideal de representação.

Uma consequência prática desse paradigma é o abandono da busca de uma linguagem ideal para representar 0 conhecimento ou de um algoritmo ideal para modelar a recuperação da informação a que aspiram ao paradigma físico e cognitivo. Uma base de dados bibliográfica ou de textos completos têm caráter eminentemente polissêmico ou, como poderíamos chamar também, polifônico. Os termos de um léxico não são algo definitivamente fixo. (CAPURRO, 2003, online)

Dando continuidade a esse pensamento, Capurro se utiliza da definição de Hjorland sobre o objeto de estudo da Ciência da Informação, e avança ao tratar da junção dos paradigmas cognitivo e social dentro de uma única perspectiva.

O objeto da Ciência da Informação é o estudo das relações entre os discursos, áreas de conhecimento e documentos em relação às possíveis perspectivas ou pontos de acesso de distintas comunidades de usuários (HJØRLAND, 2003). Isso significa, em outras palavras, uma integração da perspectiva individualista e isolacionista do paradigma cognitivo dentro de um contexto social no qual diferentes comunidades desenvolvem seus critérios de seleção e relevância. (CAPURRO, 2003, on-line)

A ideia de que os processos informativos que se utilizam de recuperação de informações mediadas pelo uso das Linguagens 
Documentárias para esse fim e que já operam com conhecimentos interpretados pode ser percebida na seguinte afirmação de Capurro:

[...] todo sistema de informação está destinado a sustentar a produção, coleta, organização, interpretação, armazenamento, recuperação, disseminação, transformação e uso de conhecimentos e deveria ser concebido no marco de um grupo social concreto e para áreas determinadas. (CAPURRO, 2003, on-line)

A criação de um sistema de informação sobre o marco de um grupo social concreto, considerando a especificidade das áreas do conhecimento, reforça a ideia de interpretação, ainda que de caráter coletivo dado pela comunidade discursiva, e torna ainda mais importante a tentativa de deixar evidenciadas as bases teóricas do processo de organização e representação da informação e do conhecimento, para que a recuperação e apropriação da informação ocorram em uma relação mais aberta, com o conhecimento da intencionalidade do emissor, seja esse a área de conhecimento e/ou a instituição que propõem a organização. 


\section{Procedimentos metodológicos}

Com o objetivo de abranger as diversas temáticas abordadas nos capítulos da revisão e mapear o uso dos termos "organização da informação" e "organização do conhecimento" como termos de descrição dos trabalhos na área de Ciência da informação e como esses se relacionam com termos como "linguagens documentárias" e "análise documentária", o procedimento metodológico adotado para o desenvolvimento da pesquisa foi o levantamento da produção científica da área de Ciência da informação.

No primeiro momento, para indicação de um panorama da produção científica em Ciência da Informação, representada pelos termos "organização da informação" e "organização do conhecimento", foi realizado levantamento:

- nos periódicos científicos ativos que compõem a base $\mathrm{BRAPCl}^{3}$ (Base de dados referencial de artigos de periódicos em Ciência da Informação);

- nas teses e dissertações do catálogo da BDTD (Biblioteca Digital Brasileira de Teses e Dissertações) ${ }^{4}$;

- nos Anais do ENANCIB ${ }^{5}$ (Encontro Nacional de Pesquisa em Ciência da Informação).

Numa segunda etapa e com o objetivo de melhor caracterizar a produção científica que se utiliza dos termos "organização da informação" e "organização do conhecimento", fizeram parte do levantamento realizado:

- os grupos de pesquisa descritos no DGP6 (Diretório de Grupos de Pesquisa do Brasil) organizado pelo CNPq

\footnotetext{
3 As informações foram coletadas no endereço da BRAPCl: <http://www.brapci.ufpr.br/ic.php?dd99=journals >.

${ }^{4} \mathrm{O}$ endereço eletrônico da BDTD é: <http://bdtd.ibict.br/vufind/>.

${ }^{5}$ A pesquisa foi realizada no portal da Ancib: <http://enancib.ibict.br/index.php/enancib/index>.

6 Realizado no endereço: <http://lattes.cnpq.br/web/dgp>.
} 
(Conselho Nacional de Desenvolvimento Científico e Tecnológico);

- e os Programas de Pós-Graduação em Ciência da Informação relacionados pela Ancib $^{7}$ (Associação Nacional de Pesquisa e Pós-Graduação em Ciência da Informação).

Para o levantamento dos artigos de periódicos científicos foram escolhidos os periódicos que fazem parte da BRAPCI (Base de Dados Referencial de Artigos de Periódicos em Ciência da Informação). A BRAPCI conta atualmente com o acervo de 25 títulos de periódicos ativos e 12 títulos de periódicos históricos ${ }^{8}$. Para o presente levantamento foram considerados 25 títulos de periódicos ativos:

1. Arquivística.net

2. AtoZ: Novas Práticas em Informação e Conhecimento

3. Biblionline

4. BIBLOS - Revista do Instituto de Ciências Humanas e da Informação

5. Brazilian Journal of Information Science

6. Ciência da Informação

7. Comunicação \& Informação

\footnotetext{
7 Disponibilizados no site da Ancib (Associação Nacional de Pesquisa e Pós-Graduação em Ciência da Informação): <http://www.ancib.org.br/>.

${ }^{8}$ São considerados periódicos históricos aqueles tiveram suas publicações suspensas. Nos casos de periódicos que por algum motivo tiveram interrupções nas suas publicações em determinado período, mas estão atualmente em atividade, os mesmos são considerados ativos.
} 
8. DataGramaZero

9. Em Questão: Revista da Faculdade de Biblioteconomia e Comunicação da UFRGS

10. Encontros Bibli: Revista Eletrônica de Biblioteconomia e Ciência da Informação

11.ETD - Educação Temática Digital

12. InCID: Revista de Ciência da Informação e Documentação

13. Inclusão Social

14. Informação \& Informação

15.Informação \& Sociedade: Estudos

16. Liinc em revista

17.Perspectivas em Ciência da Informação

18. Perspectivas em Gestão \& Conhecimento

19.Ponto de Acesso

20. Revista ACB: Biblioteconomia em Santa Catarina

21. Revista Brasileira de Biblioteconomia e Documentação

22. Revista Digital de Biblioteconomia \& Ciência da Informação

23. Revista Ibero-Americana de Ciência da Informação

24. Tendências da Pesquisa Brasileira em Ciência da Informação 


\section{Transinformação}

A pesquisa foi realizada diretamente nos sites das revistas selecionadas para que os números atuais também fossem contemplados ${ }^{9}$.

Já a produção acadêmica representada por teses e dissertações foi levantada junto ao portal da BDTD (Biblioteca Digital Brasileira de Teses e Dissertações), que reúne as teses e dissertações defendidas em diversas instituições acadêmicas do país, entre as quais estão as instituições que contam com programas de pós-graduação em Ciência da Informação. Sendo assim, a busca no portal BDTD facilita a recuperação dos registros desse tipo de produção.

Os trabalhos de evento que compõem o corpus da pesquisa são os artigos resultantes das comunicações orais feitas nos ENANCIBs (Encontro Nacional de Pesquisa em Ciência da Informação) que tem registros disponibilizados no Portal de Eventos da ANCIB. Até este ano, foram realizados 15 ENANCIBs, tendo o primeiro Encontro ocorrido em 1994.

Seguindo os critérios adotados para o levantamento, só foram selecionados artigos a partir do $\mathrm{V}$ ENANCIB, pois nos Encontros anteriores não há registro de comunicações com a presença dos termos "organização da informação" e "organização do conhecimento" no item palavras-chaves nos documentos disponibilizados no Portal da ANCIB.

Os Grupos de Pesquisas que figuram no corpus do levantamento são aqueles que fazem parte do DGP (Diretório dos Grupos de Pesquisa) no Brasil, administrado pelo CNPq (Centro Nacional de Desenvolvimento Científico e Tecnológico). O referido diretório apresenta dados referentes aos Grupos de Pesquisa como recursos humanos, linhas de pesquisas, as

\footnotetext{
${ }^{9}$ Os números que estão disponíveis no portal da BRAPCI não são os mais recentes.
} 
especialidades do conhecimento, as parcerias entre os grupos e as instituições, criando assim um perfil da atividade científico-tecnológica no Brasil.

Também foi realizado o levantamento dos Programas de PósGraduação em Ciência da Informação e suas respectivas linhas de pesquisa e membros. Como base para o referido levantamento considerou-se os Programas de Pós-Graduação em Ciência da Informação stricto sensu, com cursos de mestrado e doutorado e que tenham sido avaliados pela CAPES (Coordenação de Aperfeiçoamento de Pessoal de Nível Superior):

1. Programa de Pós-Graduação em Ciência da Informação (IBICT-UFRJ)

2. Programa de Pós-Graduação em Ciência da Informação (UEL)

3. Programa de Pós-Graduação em Ciência da Informação (UFBA)

4. Programa de Pós-Graduação em Ciência da Informação (UFF)

5. Programa de Pós-Graduação em Ciência da Informação (UFMG)

6. Programa de Pós-Graduação em Ciência da Informação (UFPB)

7. Programa de Pós-Graduação em Ciência da Informação (UFPE)

8. Programa de Pós-Graduação em Comunicação e Informação (UFRS)

9. Programa de Pós-Graduação em Ciência da Informação (UFSC)

10.Programa de Pós-Graduação em Ciência da Informação (UNB)

11.Programa de Pós-Graduação em Ciência da Informação (UNESP)

12.Programa de Pós-Graduação em Memória Social (UNIRIO)

13.Programa de Pós-Graduação em Museologia e Patrimônio (UNIRIO) 


\section{Programa de Pós-Graduação em Ciência da Informação (USP)}

Para o levantamento do corpus da pesquisa, a estratégia de busca utilizada foi a realização da busca pelos termos "organização da informação" e "organização do conhecimento". Como critério de seleção, a partir dos resultados recuperados, foi necessária a verificação da presença das expressões buscadas no campo assunto da descrição dos itens recuperados ou, quando esse não existia, no registro expandido. Quando o periódico não apresentava mecanismo de busca automática, foi realizada a triagem no documento disponível online, do item "palavras-chaves" para levantar os itens que continham os termos alvo da pesquisa ${ }^{10}$.

Os resultados recuperados das buscas com os termos "organização da informação" e "organização do conhecimento" nos periódicos, no portal BDTD e no DGP recuperaram itens que não apresentavam os termos específicos, mas termos com partes das expressões buscadas como, por exemplo, "organização da informação científica", "ciência da informação", "sistemas de organização do conhecimento" e "gestão do conhecimento". O que tornou necessário uma triagem dos resultados de busca a fim de selecionar os itens que contivessem especificamente os termos desejados.

\subsection{Análise e discussão dos resultados}

Após o levantamento e a seleção, o corpus resultante para a presente pesquisa foi de 219 registros entre artigos de periódicos, trabalhos de eventos, teses e dissertações; 54 Grupos de Pesquisa; e 14 Programas de Pós-Graduação em Ciência da Informação.

$\mathrm{Na}$ busca em periódicos, as revistas Arquivística.net, Biblionline, Biblios, Comunicação \& Informação, Inclusão Social, Liinc, Tendências da Pesquisa Brasileira em Ciência da Informação e Transinformação não

10 O periódico DataGramaZero não disponibiliza nenhum recurso de busca automática aos artigos que publica, sendo necessário a verificação da presença dos termos de interesse da pesquisa no sumário dos artigos. 
apresentaram nenhum resultado de recuperação com os termos "organização da informação" e "organização do conhecimento" nas palavras-chave. Somente as revistas AtoZ, Brazilian Journal of Information Science, Ciência da Informação, DataGramaZero, Em Questão, Encontros Bibli, ETD, InCID, Informação \& Informação, Informação \& Sociedade, Perspectivas em Ciência da Informação, Perspectiva em Gestão \& Conhecimento, Ponto de Acesso, ACB, Revista Brasileira de Biblioteconomia e Documentação, Revista Digital de Biblioteconomia e Ciência da Informação, Revista Iberoamericana de Ciência da Informação, apresentaram ocorrências com os termos de buscas em suas palavras-chave.

Seguindo o critério de triagem especificada para busca dos termos, as revistas que tiveram mais artigos selecionados foram:

- revista DataGramaZero, com 19 artigos;

- revista Informação \& Informação, com 15 artigos;

- revista Encontros Bibli: Revista Eletrônica de Biblioteconomia e Ciência da Informação, com 12 artigos;

- revista Ciência da Informação, com 10 artigos selecionados.

As outras revistas tiveram menos de dez artigos selecionados, conforme distribuição abaixo:

- revista Perspectivas em Ciência da Informação (8 artigos);

- revista Digital de Biblioteconomia \& Ciência da Informação (5 artigos);

- revista InCID (5 artigos);

- revista Ibero-Americana de Ciência da Informação (4 artigos); 
- revista Ponto de Acesso (4 artigos);

- revista Em Questão (3 artigos);

- revista Informação \& Sociedade (3 artigos);

- revista Perspectivas em Gestão \& Conhecimento (2 artigos);

- revista Digital de Biblioteconomia e Documentação (1 artigo);

- revista ACB (1 artigo);

- revista AtoZ (1 artigo);

- revista Brazilian Journal of Information Science (1 artigo);

- revista ETD (1 artigo)

O total de artigos selecionados para compor o corpus de análise foi de 98 artigos.

A esse montante de artigos podemos juntar as produções dos outros segmentos de divulgação científica, como as teses e dissertações e os trabalhos de evento.

No Portal BDTD, a busca realizada com os mesmos termos exatos, "organização da informação" e "organização do conhecimento", no campo assunto e com o qualificador "teses", resultou em 11 documentos selecionados, e, com o qualificador "dissertações", foram selecionados 50 documentos.

Para o levantamento dos trabalhos de eventos, constituídos pelas comunicações orais apresentadas nos ENANCIBs, as buscas foram realizadas nos trabalhos do GT-2 Organização e Representação do Conhecimento, por ser este o Grupo que aglutina as discussões referentes à Organização da 
Informação e Organização do Conhecimento enquanto temáticas de pesquisa ${ }^{11}$. A seleção ocorreu com a verificação manual ${ }^{12}$ da ocorrência dos termos "organização da informação" e "organização do conhecimento" no campo das palavras-chave dos artigos apresentados e apresentou, como resultado, um corpus de 60 documentos.

O total do corpus selecionado, entre artigos, teses, dissertações e trabalhos de evento, foi de 219 documentos (Apêndice A).

Na Tabela 1, está apresentada a distribuição dos termos no corpus selecionado. Pode-se verificar um equilíbrio na ocorrência dos termos "organização da informação" e "organização do conhecimento" nos artigos de periódicos. Tal equilíbrio não ocorre nas teses e dissertações, que têm predominância do termo "organização da informação".

Tabela 1. Produção científica descrita com os termos: Ol (organização da informação); OC (organização do conhecimento); OI/OC (organização da informação e organização do conhecimento).

\begin{tabular}{|r|c|c|c|c|}
\hline Tipo de produção & OI & OC & OI/OC & Total \\
\hline $\begin{array}{r}\text { Artigos de periódicos } \\
\text { científicos }\end{array}$ & 43 & 45 & 10 & 98 \\
\hline Teses & 9 & 1 & 1 & 11 \\
\hline Dissertações & 37 & 9 & 4 & 50 \\
\hline $\begin{array}{r}\text { Trabalhos de eventos - } \\
\text { ENANCIB }\end{array}$ & 32 & 24 & 4 & 60 \\
\hline Total por qualidade & 121 & 79 & 19 & 219 \\
\hline
\end{tabular}

Uma possível interpretação para essa diferença entre os tipos de produção e as formas de representação, "organização da informação" e

11 Atualmente os trabalhos com a temática Organização da Informação e Organização do conhecimento são aglutinados no GT-2 Organização e Representação do Conhecimento. No entanto o GT-2 já teve outras denominações indicando as mudanças de delimitações temática do grupo e também da área. A ementa do Grupo de Trabalho está disponível em: $<$ http://gtancib.fci.unb.br/index.php/gt-02>.

12 A pesquisa com o uso do sistema de busca disponibilizado pelo portal da ANCIB só recuperou trabalhos realizados no XII ENANCIB, o que tornou necessário verificar individualmente cada um dos artigos nas demais conferências. 
"organização do conhecimento", pode ocorrer devido à natureza desses tipos de produção científica, uma vez que cada um conta com objetivos, formatos de apresentação, formas de produção e circulação distintas.

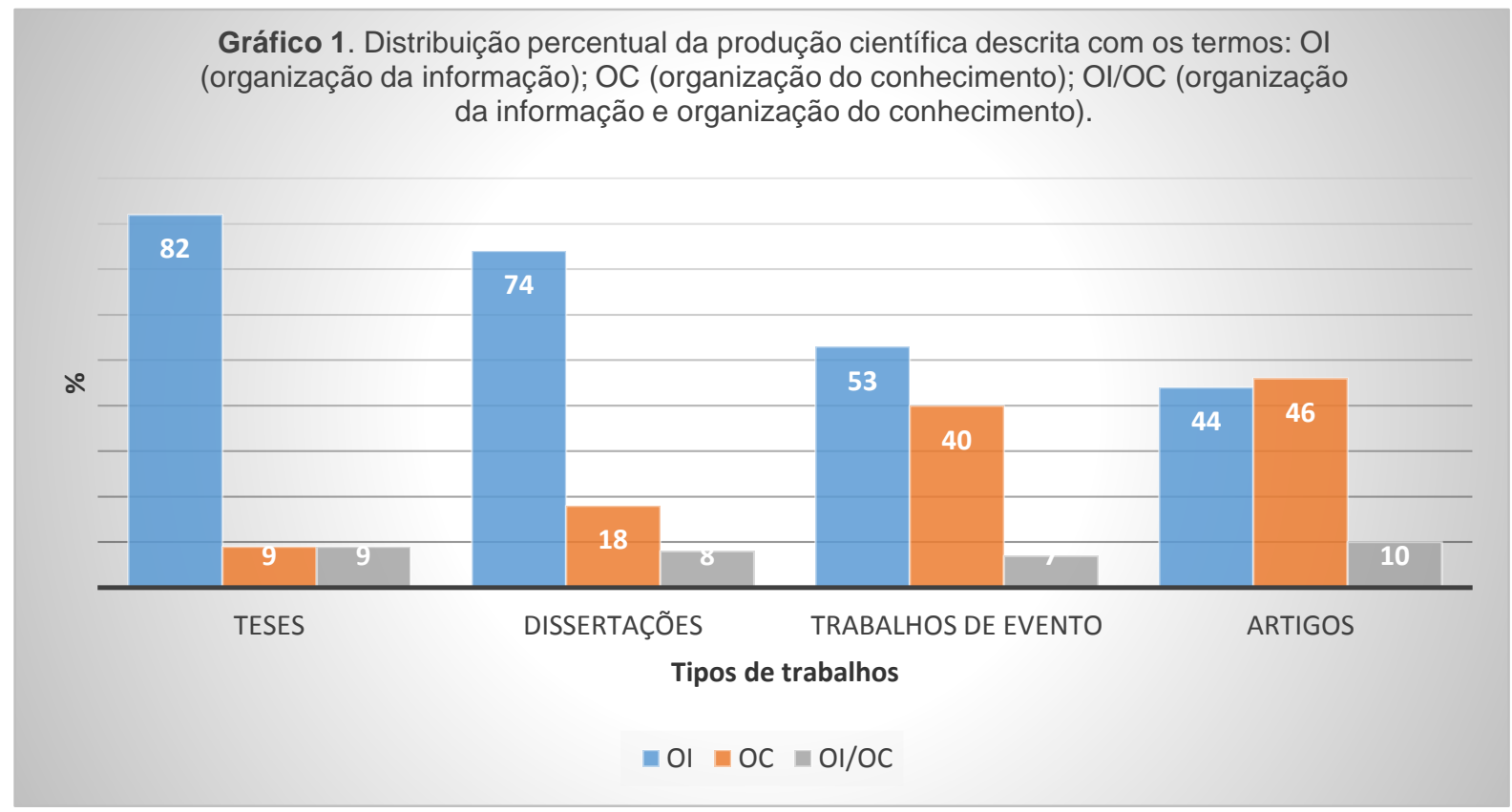

Como o ilustrado pelo Gráfico 1, é possível percebermos a predominância da representação da produção científica descrita pelo termo "organização da informação", quando observamos o corpus no seu total. Quanto à observação por tipo de produção, podemos notar um equilíbrio nas produções tidas como mais dinâmicas e indicativas dos temas em maior evidência na área científica, que são os trabalhos de eventos e artigos de periódicos.

Sendo assim, é possível propor uma interpretação para a predominância dos trabalhos representados pelo termo "organização da informação", uma vez que é sabido haver um movimento de retroalimentação entre os temas de pesquisas e também entre os trabalhos acadêmicos. Assim, ainda que se espere das teses e dissertações uma produção com a responsabilidade de trazer novas contribuições para suas áreas de 
conhecimento, elas, muitas vezes, repercutem e reelaboram temas já consolidados na área.

Essa não é uma crítica a esse tipo de trabalho, mas sim, a notação de uma característica dessa produção, pois esses são trabalhos de pesquisas, vinculados a Programas de Pós-Graduação específicos, com suas ementas e linhas de pesquisas definidas, em que as pesquisas a eles vinculadas não podem deixar de atender aos objetivos do Programa.

É preciso considerar, ainda, que as teses e as dissertações são trabalhos de "maior fôlego" e, por isso, a retomada de questões já discutidas e consolidadas na área estejam mais presentes. Não é possível esquecer, ainda, que esses são trabalhos elaborados e avaliados para a atribuição de uma titulação ao seu autor, o que pode levar seus autores a discutirem assuntos já trabalhados, como uma forma de segurança e de se arriscarem menos em temáticas ainda novas na área.

Por sua vez, a produção científica representada pelos trabalhos de eventos e artigos de periódicos apresentam outras características. Esses trabalhos ora têm por característica apresentar discussões em andamento na área (que em muitos casos culminam na produção de teses e dissertações), ora apresentam para comunidade científica a introdução de novas discussões a fim de perceber na comunidade científica a aceitação ou rejeição do tema e/ou perspectiva de análise, bem como a sua reverberação nas discussões subsequentes.

A observação da distribuição temporal do corpus da produção científica descrita com os termos "organização da informação" e "organização do conhecimento" contribui para essa discussão. 


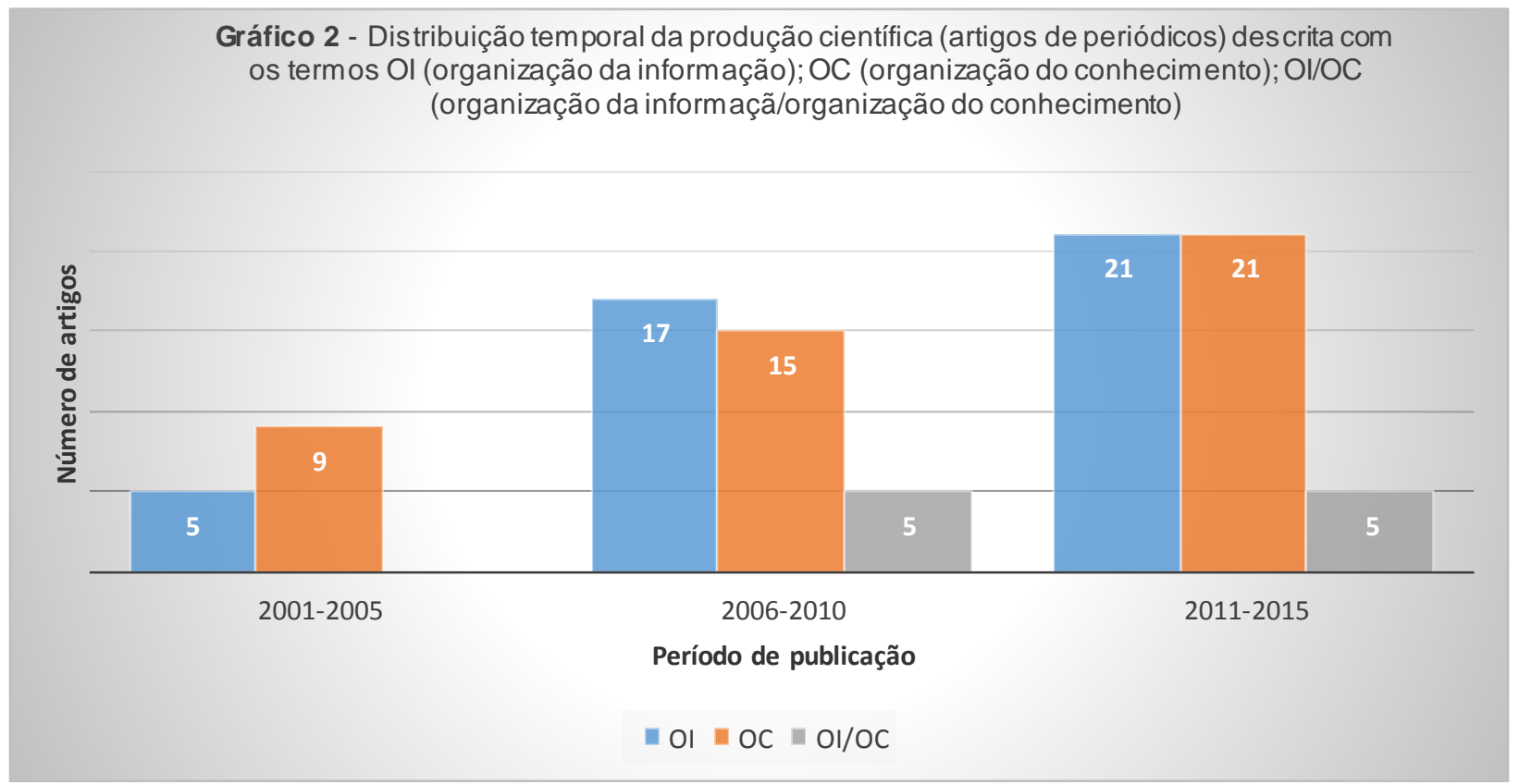

A distribuição temporal dos artigos de periódicos mostra que há uma produção crescente relacionada aos termos de busca que são alvo da pesquisa. É que essa produção cresce com a tendência de equiparação no volume de produção descrita pelos temas, ou até mesmo é possível haver uma indicação de crescimento maior da produção descrita por "organização do conhecimento".

Já no Gráfico 3, com a distribuição da produção representada pelas teses e dissertações, essa tendência não se mantém. No entanto, é preciso considerar que o volume de trabalhos selecionados nesse tipo de material é pequeno e a distribuição temporal desses trabalhos apresenta um menor intervalo. Novamente, a possibilidade levantada para essa situação recai sobre a natureza desse tipo de produção, uma vez que ela é uma produção mais lenta, em que os temas levam mais tempo para aparecer. 
Gráfico 3 - Distribuição temporal da produção científica (teses) descrita com os termos OI (organização da informação); OC (organização do

conhecimento); Ol/OC (organização da informaçã/organização do conhecimento)

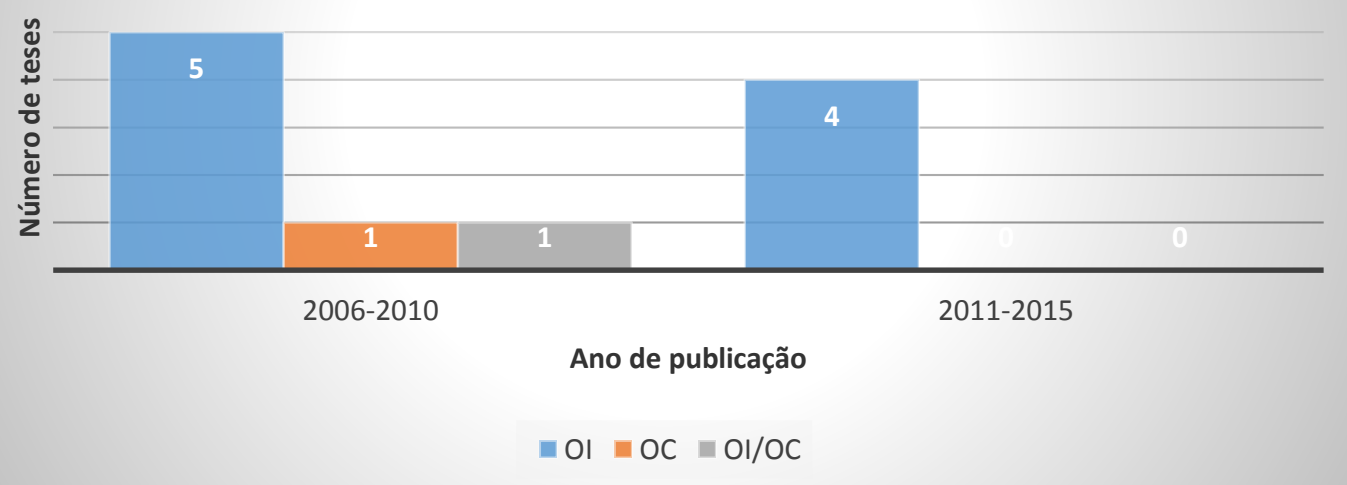

Na distribuição temporal das dissertações que compõem o corpus da pesquisa (Gráfico 4), existe uma produção significativa de trabalhos representados por "organização da informação" e alguns poucos representados por "organização do conhecimento.

Ao analisarmos conjuntamente a produção das dissertações e teses, uma interpretação possível para 0 volume de produção e sua distribuição temporal, além da já levantada característica do tempo de produção e natureza do trabalho, é a de que os novos temas de pesquisa de uma área demoram mais tempo para aparecer nas teses do que nas dissertações, e o volume diminui em ambos os casos de descrição, "organização da informação" e "organização do conhecimento", devido ao tempo de produção das teses. 


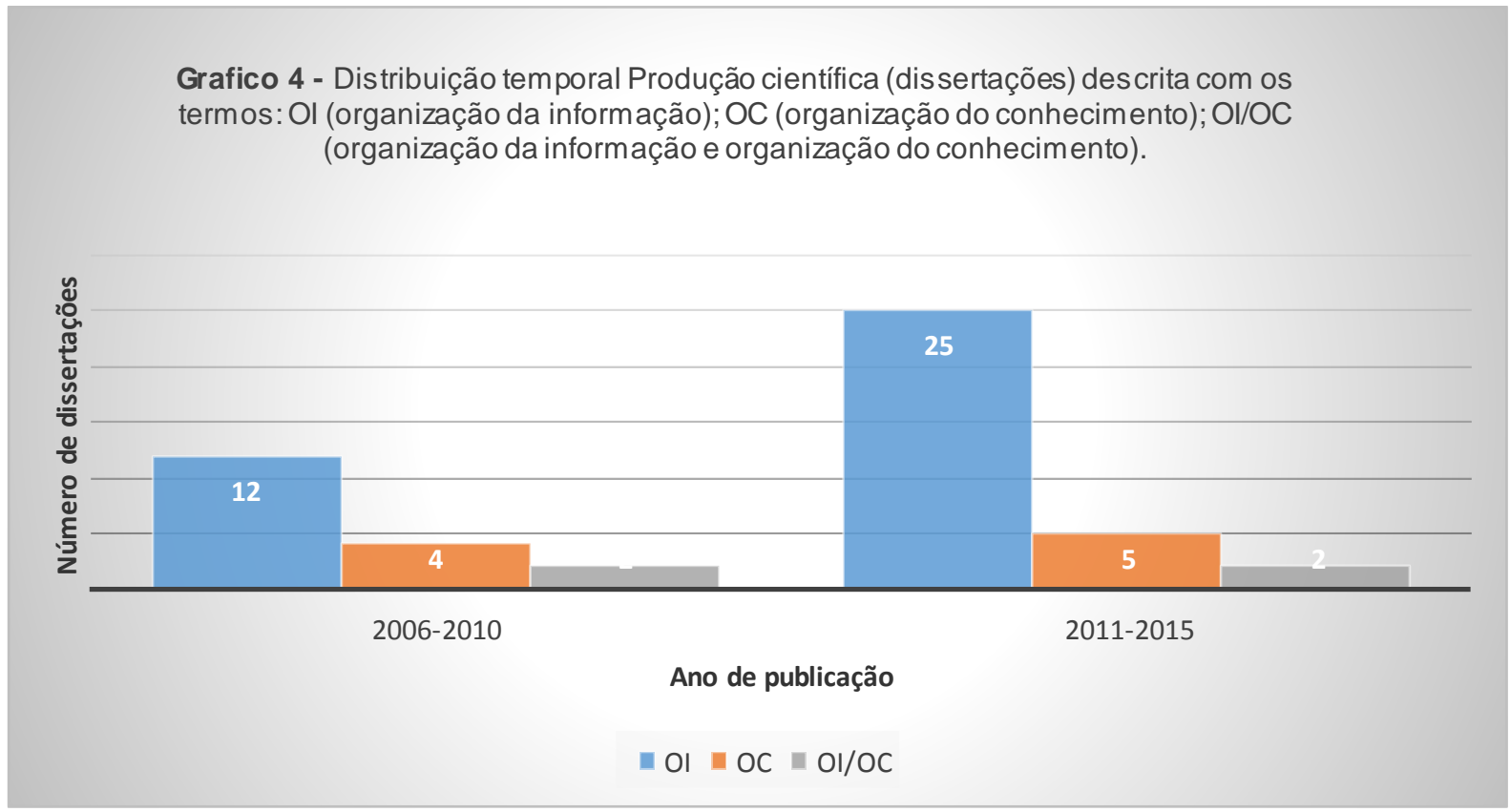

Ao analisarmos a produção dos trabalhos de eventos que, em tese, apresentam os temas mais novos de uma área de conhecimento, podemos enxergar um possível caminho dos temas Organização da Informação e Organização do conhecimento dentro da Ciência da informação.

O Gráfico 5, com a distribuição temporal dos trabalhos apresentados no GT-2 do ENANCIB ao longo dos anos, mostra o aparecimento dos temas no intervalo dos anos 2000-2005. Já no intervalo temporal subsequente, 2006-2010, ocorreu o maior volume de trabalhos descritos com os termos buscados. Por sua vez, o último intervalo temporal, 2011-2015, mostra uma diminuição no volume total de trabalhos descritos com os termos "organização da informação" e "organização do conhecimento".

Assim, a tendência temática Organização da Informação e Organização do Conhecimento é percebida na produção dos trabalhos eventos, no que podemos chamar respectivamente de período de surgimento, auge e consolidação dos temas na área, dentro de um intervalo total de 15 anos. 


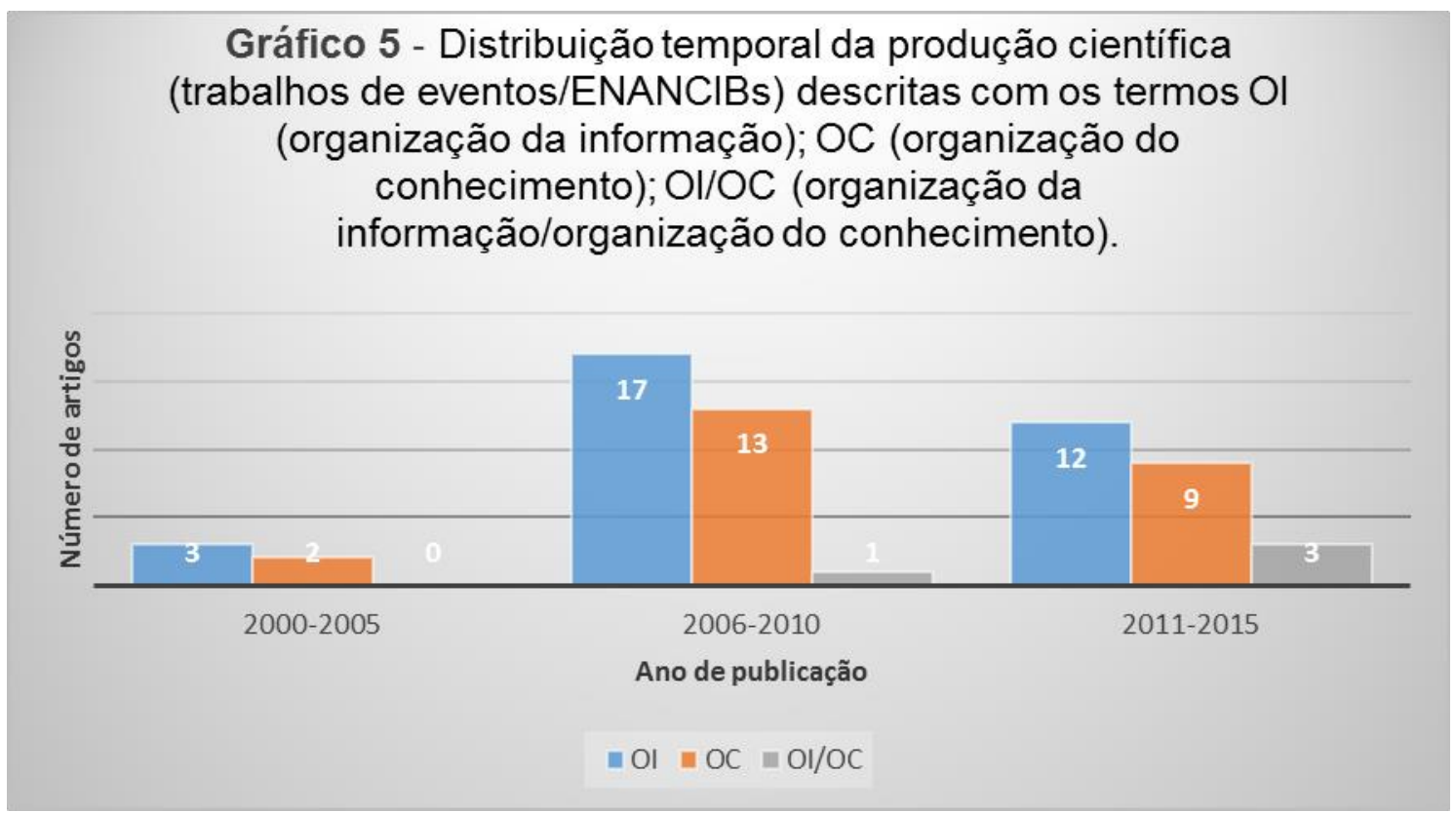

A distribuição temporal do corpus no seu total (Gráfico 6) também aponta para o aparecimento das formas de representação "organização da informação" e "organização do conhecimento" para o período entre 2000-2005. Com o crescimento acentuado no período seguinte, sendo que no último período, o crescimento se mantém, mas não com a mesma intensidade.

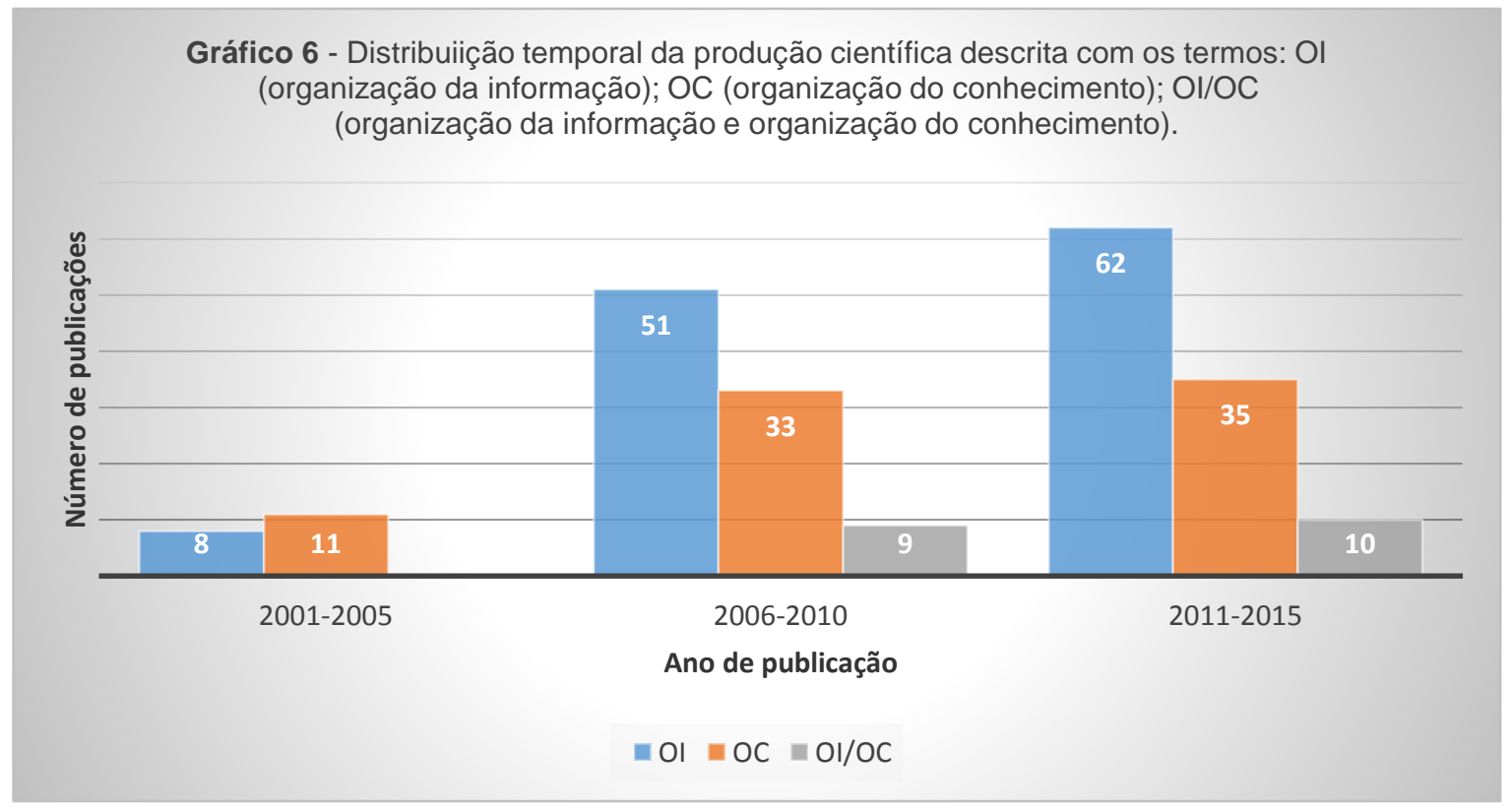


Considerando a representação dos trabalhos com o uso simultâneo dos termos "organização da informação" e "organização do conhecimento", descritos nas tabelas e gráficos como Ol/OC, o que percebemos através dos dados coletados é que existe o uso conjunto dos termos, mas que esses trabalhos não representam um volume significativo no total da produção científica da área. Ainda assim, os dados nos mostram que a produção descrita por "organização da informação" é a mais volumosa.

Da mesma maneira, nos Grupos de Pesquisa, Tabela 2, apresentam maior ocorrência de recuperação pelo uso do termo "organização da informação". Porém, a diferença no número de grupos recuperados é menor se em comparação ao corpus selecionado da produção científica.

Tabela 2. Grupos de Pesquisas identificados com os termos: Ol (organização da informação); OC (organização do conhecimento); OI/OC (organização da informação e organização do conhecimento).

\begin{tabular}{|r|c|c|c|c|}
\hline Ocorre na descrição & OI & OC & Ol/OC & Total \\
\hline Grupos & 35 & 26 & 7 & 54 \\
\hline
\end{tabular}

Estas indicações de ocorrência já não são verificadas nas linhas e áreas de concentração dos Programas de Pós-Graduação em Ciência da Informação, conforme indicado na Tabela 3. Todos os programas apresentam os termos "organização", "informação" e/ou "conhecimento", mas não com a expressão exata "organização da informação" e "organização do conhecimento".

Uma hipótese para a presente situação é a necessidade dos Programas de Pós-Graduação em Ciência da Informação de terem em suas descrições, caracterizadas por suas Áreas de Concentração e Linhas de Pesquisas, termos mais abrangentes, como "informação", "organização", "conhecimento", "cultura" e "sociedade", com o intuito de ampliar as possibilidades temáticas de sua atuação. 


\begin{tabular}{|c|c|}
\hline \multicolumn{2}{|c|}{$\begin{array}{c}\text { Tabela } 3 \text { - Área de Concentração e Linhas de Pesquisas dos Pós-Graduação em } \\
\text { Ciência da Informacão }\end{array}$} \\
\hline \multirow{4}{*}{$\begin{array}{l}\text { Universidade de } \\
\text { Londrina (UEL) }\end{array}$} & Área de concentração \\
\hline & Não consta \\
\hline & Linhas de pesquisa \\
\hline & $\begin{array}{l}\text { 1. Organização e Representação da Informação e do } \\
\text { Conhecimento } \\
\text { 2. Compartilhamento da Informação e do Conhecimento }\end{array}$ \\
\hline \multirow{4}{*}{$\begin{array}{r}\text { Universidade } \\
\text { Federal da Bahia } \\
\text { (UFBA) }\end{array}$} & Área de concentração \\
\hline & Informação e Conhecimento na Sociedade Contemporânea \\
\hline & Linhas de pesquisa \\
\hline & $\begin{array}{l}1 \text { - Políticas, tecnologias e usos da informação; } \\
2 \text { - Produção, circulação e mediação da informação. }\end{array}$ \\
\hline \multirow{4}{*}{$\begin{array}{r}\text { Universidade } \\
\text { Federal } \\
\text { Fluminense (UFF) }\end{array}$} & Área de concentração \\
\hline & Dimensões contemporâneas da informação e do conhecimento \\
\hline & Linhas de pesquisa \\
\hline & $\begin{array}{l}1 \text { - informação, cultura e sociedade } \\
2 \text { - fluxos e mediações sócio-técnicas da informação }\end{array}$ \\
\hline \multirow{4}{*}{$\begin{array}{r}\text { Universidade } \\
\text { Federal de Minas } \\
\text { Gerais }\end{array}$} & Área de concentração \\
\hline & Produção, organização e utilização da informação \\
\hline & Linhas de pesquisa \\
\hline & $\begin{array}{l}\text { Gestão da Informação e do Conhecimento - GIC } \\
\text { Informação, Cultura e Sociedade - ICS } \\
\text { Organização e Uso da Informação - OUI }\end{array}$ \\
\hline \multirow{4}{*}{$\begin{array}{r}\text { Universidade } \\
\text { Federal de } \\
\text { Pernambuco }\end{array}$} & Área de concentração \\
\hline & Informação, memória e tecnologia \\
\hline & Linhas de pesquisa \\
\hline & $\begin{array}{l}\text { 1. memória da informação científica e tecnológica } \\
\text { 2. comunicação e visualização da memória }\end{array}$ \\
\hline \multirow{4}{*}{$\begin{array}{r}\text { Universidade } \\
\text { Federal do Rio } \\
\text { Grande do Sul } \\
\text { (UFRGS) }\end{array}$} & Área de concentração \\
\hline & Comunicação e Informação \\
\hline & Linhas de pesquisa \\
\hline & Não consta \\
\hline \multirow{4}{*}{$\begin{array}{r}\text { Universidade } \\
\text { Federal do Rio de } \\
\text { Janeiro (UFRJ) }\end{array}$} & Área de concentração \\
\hline & Não consta \\
\hline & Linhas de pesquisa \\
\hline & $\begin{array}{l}\text { 1. Comunicação, Organização e Gestão da Informação e do } \\
\text { Conhecimento } \\
\text { 2. Configurações socioculturais, políticas e econômicas da } \\
\text { informação }\end{array}$ \\
\hline \multirow{4}{*}{$\begin{array}{r}\text { Universidade } \\
\text { Federal de Santa } \\
\text { Catarina (UFSC) }\end{array}$} & Área de concentração \\
\hline & Gestão da Informação \\
\hline & Linhas de pesquisa \\
\hline & $\begin{array}{l}\text { 1. Organização, representação e mediação da informação e do } \\
\text { conhecimento } \\
\text { 2. Informação, gestão e tecnologia }\end{array}$ \\
\hline \multirow{3}{*}{$\begin{array}{l}\text { Universidade de } \\
\text { Brasília (UnB) }\end{array}$} & Área de concentração \\
\hline & Gestão da Informação \\
\hline & Linhas de pesquisa \\
\hline
\end{tabular}




\begin{tabular}{|c|c|}
\hline & $\begin{array}{l}\text { 1. Organização da Informação } \\
\text { 2. Comunicação e Mediação da Informação }\end{array}$ \\
\hline \multirow{4}{*}{ UNESP } & Área de concentração \\
\hline & Informação, Tecnologia e Conhecimento \\
\hline & Linhas de pesquisa \\
\hline & $\begin{array}{l}\text { 1. Informação e Tecnologia; } \\
\text { 2. Produção e Organização da Informação; } \\
\text { 3. Gestão, Mediação e Uso da Informação. }\end{array}$ \\
\hline \multirow{4}{*}{ UNIRIO } & Área de concentração \\
\hline & Estudos interdisciplinares em Memória Social \\
\hline & Linhas de pesquisa \\
\hline & $\begin{array}{l}\text { 1. Memória e Patrimônio } \\
\text { 2. Memória e Linguagem } \\
\text { 3. Memória e Espaço }\end{array}$ \\
\hline \multirow{4}{*}{ UNIRIO } & Área de concentração \\
\hline & Não consta \\
\hline & Linhas de pesquisa \\
\hline & Memória, Subjetividade e Criação \\
\hline \multirow{4}{*}{$\begin{array}{l}\text { Universidade de } \\
\text { São Paulo (USP) }\end{array}$} & Área de concentração \\
\hline & Cultura e Informação \\
\hline & Linhas de pesquisa \\
\hline & $\begin{array}{l}\text { Apropriação Social da Informação } \\
\text { Gestão de Dispositivos de Informação } \\
\text { Organização da Informação e do Conhecimento }\end{array}$ \\
\hline
\end{tabular}

Com a análise da produção científica descrita por "organização da informação" e "organização do conhecimento", dos Grupos de Pesquisas descritos com os referidos termos e a verificação da presença dos mesmos na descrição dos Programas de Pós-Graduação, é possível afirmar a presença expressiva das temáticas na área de Ciência da informação.

A partir dessa verificação, é possível tentar mapear as relações temáticas criadas pelos trabalhos de Organização da informação e do Conhecimento, através dos demais termos de descrição que ocorrem conjuntamente com "organização da informação" e/ou "organização do conhecimento". Nesse levantamento, foi dada maior atenção as relações existentes entre os termos de buscas e a presença dos termos de descrição "análise documentária" e "linguagem documentaria".

Após a listagem dos termos que ocorrem junto a "organização da informação" e "organização do conhecimento" no corpus da produção científica 
selecionado, chegou-se a ocorrência associada de mais de 400 termos, como o apresentado na Tabela 4 (Apêndice B).

O primeiro dado que requer atenção, a partir da verificação dos termos que ocorrem junto com "organização da informação" e "organização do conhecimento", é a variedade, tanto de termos como das temáticas relacionadas.

Outro dado significativo é o elevado número de termos com apenas uma ocorrência. Isso ocorre por causa da variedade temática, como dos critérios distintos adotados para atribuição desses termos junto à produção científica selecionada.

Voltando a atenção para os termos que aparecem mais vezes juntos aos termos "organização da informação" e "organização do conhecimento", os termos como maior número de ocorrência são: "representação da conhecimento" (23), "Ciência da Informação" (22), "representação da informação" (21), "recuperação da informação" (19), Indexação (13), Ontologia (13), "linguagem documentária" (10), "gestão da informação" (7), "tratamento temático da informação" (7) e "tesauros" (7).

Uma interpretação mais provável para a ocorrência do termo "Ciência da Informação" ser o segundo com maior ocorrência se deve ao fato de ser a área de conhecimento na qual estão inseridos os temas pesquisados.

Já ocorrência massiva dos termos "representação da informação" e "representação do conhecimento" junto aos termos buscados, acontece quase por uma associação necessária entre organização da informação/representação da informação e organização do conhecimento/representação do conhecimento. No entanto, é relevante notar a natureza dessa associação. Segundo a literatura da área de Ciência da Informação, a Organização da informação e a Organização do Conhecimento são subáreas com propostas teóricas e formas de pensar a organização da informação e do conhecimento, e o resultado dessas propostas são 
materializados nas formas de representação, daí a associação entre os termos em questão.

Nesse sentido, ainda temos a presença expressiva dos termos "ontologia", "linguagem documentária" e "tesauros", ampliando ainda mais a observação para outros instrumentos de representação da informação. Também são registradas ocorrências dos termos "taxonomia" (6) e "vocabulário" (5).

Por sua vez, a ocorrência do termo "Análise Documentária" (4), se mostrou menos expressiva. Uma possível hipótese para essa situação é o fato de Análise Documentária ser também uma área de conhecimento dentro da Ciência da Informação, e não apenas uma etapa no processo de tratamento da informação, como o evidenciado no referencial teórico apresentado. Assim, a associação entre os termos "organização da informação", "organização do conhecimento" e "Análise Documentária" é dificultada por uma necessidade de delimitação do escopo de atuação dessas subáreas da Ciência da Informação.

No entanto, como o referencial teórico apresentado mostrou que, historicamente, a elaboração das linguagens documentárias estava sobre a alçada da Análise Documentária, o levantamento dos termos junto à produção científica descrita com os termos "organização da informação" e "organização do conhecimento" aponta, ainda que discretamente, para uma possível transferência ou compartilhamento da responsabilidade do pensar esses instrumentos para as áreas de Organização da Informação e Organização do Conhecimento.

Uma hipótese mais arriscada, mas com possibilidade de ser checada, é uma possível evolução, substituição, e/ou transferência do escopo de atuação da Análise Documentária para as áreas de Organização da Informação e Organização do Conhecimento, indicando assim uma superação da Análise Documentária como área de atuação dentro da Ciência da Informação, tendo seus objetivos transferidos ou realocados em uma nova divisão conceitual da área. 
Em linhas gerais, o que os dados nos mostram até aqui é que a produção científica em Ciência da Informação e as outras formas de expressão da área, representadas pelos Grupos de Pesquisas e os Programas de PósGraduação representados por "organização da informação" e "organização do conhecimento", apresenta a predominância da descrição por "organização da informação". Uma hipótese possível para esse movimento, sobretudo na produção científica em Ciência da Informação, pode ser a presença anterior do tema Organização da Informação nas discussões e análises promovidas dentro da Ciência da Informação, sob a alçada de outras formas de denominação, como seria o caso da Análise Documentária enquanto área. Ainda que a distribuição temporal do corpus não tenha evidenciado a presença significativa dos termos de representação "organização da informação" e "organização do conhecimento", essa hipótese não pode ser afastada, pois tratamos apenas da presença dessas expressões como formas de representação e não através de uma análise da produção qualitativa dos trabalhos, o que requer um levantamento mais extensivo da produção e uma observação dessa produção enquanto resultado de contribuição teórica para área.

Outro indicativo importante da análise dos dados coletados é o fato de que ainda que ocorram conjuntamente como formas de representação "organização da informação" e "organização do conhecimento", as áreas de conhecimento que começam a surgir na produção científica da Ciência da Informação no Brasil no início dos anos 2000, caminham para uma atuação distinta. 


\section{Considerações Finais}

A pesquisa trouxe contribuições para discussão da atual forma tomada pela Ciência da Informação, enquanto área de conhecimento. A preocupação com as formas de representação da área representada pelas formas de descrição de sua produção, no caso específico da pesquisa, da produção descrita por "organização da informação" e "organização do conhecimento", possibilitou perceber como as subáreas de conhecimento Organização da Informação e Organização do Conhecimento traçaram um caminho dentro da Ciência da Informação.

Quer seja pelo o volume de produção levantado, quer seja pela sua distribuição temporal ou ainda pelas variações de relação evidenciadas pelos diferentes termos associados aos termos "organização da informação" e "organização do conhecimento", o que a pesquisa mostrou é que, tanto a Organização da Informação quanto a Organização do Conhecimento, são duas áreas temáticas já consolidadas na produção científica da Ciência da Informação, ainda que não tenha sido possível confirmar a hipótese da presença primeira do tema organização da informação por meio do uso dos termos de descrição buscados, tão pouco essa primazia pode ser atribuída ao tema organização do conhecimento. Para que se possa confirmar ou refutar essa hipótese, outros estudos serão necessários.

Mas, ainda dentro da dinâmica de conformação da Ciência da Informação como área maior de conhecimento, a pesquisa indicou a possibilidade da ocorrência de substituição/superação/incorporação de subáreas, historicamente significativas na conformação do campo, como no caso a Análise Documentária, por novas discussões representadas pelas novas subáreas do campo, no caso específico a Organização da Informação e Organização do Conhecimento. Nesse sentido, a pesquisa mostrou haver uma movimentação mais intensa na conformação teórica das subáreas dentro da Ciência da Informação, pois a atuação final continua sendo percebida na produção por meio da presença dos termos que 
indicam os trabalhos que se referem aos instrumentos de representação. É como se a área de Ciência da Informação estivesse repensando suas formas de organização interna, mas não deixando de atuar com suas formas de contribuição para a sociedade.

Enquanto metodologia de pesquisa, o trabalho ratificou a importância das palavras-chaves e termos indexados como instrumentos importantes para se conhecer a produção científica de uma área de conhecimento e, através deles perceber o caminho temático percorrido pela área de Ciência da Informação. 
Referências

BARReto, A. A. A questão da informação. Revista São Paulo em Perspectiva, São Paulo, v. 8, n.4, p. 3-8, 1994.

BOCATTO, Vera Regina C. Estudos de linguagem em ciência da informação. Campinas: Alínea, 2011.

BRASCHER, Marisa; CAFÉ, Ligia. Organização da Informação ou Organização do Conhecimento? In: ENCONTRO NACIONAL DE PESQUISA EM CIÊNCIA DA INFORMAÇÃO, 9, 2008. São Paulo, Anais... São Paulo, USP, 2008.

Disponível em:

$<$ http://enancib.ibict.br/index.php/enancib/ixenancib/paper/viewFile/3016/2142>. Acesso em: 14 jul. 2015.

BURKE, Peter. História social do conhecimento: de Gutenberg a Diderot. Rio de janeiro: Jorge Zahar, 2003.

CAPURRO, Rafael. Epistemologia e ciência da informação. In: ENCONTRO NACIONAL DE PESQUISA EM CIÊNCIA DA INFORMAÇÃO, 5., 2003, Belo Horizonte. Anais... Belo Horizonte: Associação Nacional de Pesquisa e PósGraduação em Ciência da Informação e Biblioteconomia, 2003.

CAPURRO, Rafael; HJORLAND, Birger. O conceito de informação.

Perspectivas em Ciência da Informação, v. 12, n. 1, p. 148-207, jan./abr. 2007. Disponível em:

$<$ http://portaldeperiodicos.eci.ufmg.br/index.php/pci/article/view/54/47> $>$. Acesso em: 19 abr. 2014.

CARLAN, Eliana. Sistemas de organização do conhecimento: uma reflexão no contexto da Ciência da Informação. 2010. 100 f. Dissertação (Mestrado) Programa de Pós-Graduação em Ciência da Informação, UnB, Brasília, 2010.

CUNHA, Isabel M. R. Ferin (Coord.). Análise documentária: considerações teóricas e experimentações. São Paulo: FEBAB, 1989.

CUNHA, Isabel M. R. Ferin. Do mito à análise documentária. São Paulo: EDUSP, 1990.

CUNHA, Isabel M. R. Ferin; KOBASHI, Nair Yumiko; AMARO, Regina Keiko Obata F. Revisão bibliográfica. In: SMIT, Johanna W. (Coord.). Análise documentária: a análise da síntese. 2. ed. Brasília: IBICT, 1987. p. 114-133. 
DAHLBERG, I. Knowledge organization: its scope and possibilities. Knowledge Organization, 20(4), 211-222, 1993.

GARCIA GUTIÉRREZ, A. L. Estructura linguistica de la documentacion: teoria y metodo. Murcia: Universidad de Murcia, 1990.

GIL URDICIAIN, Blanca. Manual de lenguajes documentales. Gijón: Trea, 2004.

GUIMARÃES, José Augusto Chaves. A dimensão teórica do tratamento temático da informação e suas interlocuções com o universo científico da International Society for Knowledge Organization (ISKO. Revista Iberoamericana de Ciência da Informação (RICl), v. 1, n. 1, p. 77-99, 2008.

KOBASHI, Nair Yumiko. Elaboração de informações documentária: em busca de uma metodologia. 1994. p. 195. Tese (Doutorado). Programa de PósGraduação em Ciência da Comunicação - Escola de Comunicações e Artes Universidade de São Paulo, São Paulo.

LARA, Marilda Lopes Ginez de. Linguística Documentária: seleção de conceitos. 2009. Tese (Livre-Docência) - Universidade de São Paulo, São Paulo, 2009.

LARA, Marilda Lopes Ginez de; Ortega Cristina Dotta. Uma abordagem contemporânea de documento na Ciência da Informação. In: SILVA, Fabiano C. C.; SALES Rodrigo. Cenários da Organização do Conhecimento: Linguagens documentárias em cena. Brasília: Thesaurus, 2011.

LE COADIC, Yves-François. A Ciência da Informação. Tradução Maria Yêda F. S. de Filgueiras Gomes. Brasília: Briquet de Lemos, 2004.

ROBREDO, Jaime. Da Ciência da Informação revisitada aos sistemas humanos de informação. Brasília: Thesaurus; SSRR Informações, 2003.

SILVA, Armando Malheiro da. Conhecimento/Informação: sinonímia e/ou diferenciação? In: RODRIGES, Georgete Medleg; LOPES, Ilza Leite (Org.). Organização e representação do conhecimento na perspectiva da Ciência da Informação. Brasília: Thesaurus, 2003. p. 23-41.

SMIT, Johanna W. (Coord.). Análise documentária: a análise da síntese. 2. ed. Brasília: IBICT, 1987.

TAYLOR, A. G. The organization of the information. 2.ed. Westport: Libraries Unlimited, 2004. 
Apêndice A - Total do corpus selecionado (artigos, teses, dissertações e trabalhos em evento).

\section{Artigos}

AGUSTÍN-LACRUZ, María del Carmen, FUJITA, Mariangela Spotti Lopes, TERRA, Ana Lúcia Silva. Linguagens documentais para as bibliotecas escolares: o caso da Espanha, Portugal e Brasil. I\&S. João Pessoa, v. 24, n. 3, p. 83-97, set/dez 2014. Disponível em: $<$ http://www.ies.ufpb.br/ojs/index.php/ies/article/view/20256/12404>. Acesso em: 24.07.15.

ALMEIDA, Maurício Barcellos; BAX, Marcello Peixoto. Uma visão geral sobre ontologias: pesquisa sobre definições, tipos, aplicações, métodos de avaliação e de construção. Ciência da Informação. Brasília, v. 32, n. 3, p. 7-20, set/dez 2003. Disponível em: <http://revista.ibict.br/index.php/ciinf/article/view/17/12>. Acesso em 24.07.15.

ALMEIDA, Maurício Barcellos; SOUZA, Renato Rocha. Avaliação do espectro semântico de instrumentos para organização da informação. Encontros Bibli. Florianópolis, v. 16, n. 31, p. 25-50, 2011. Disponível em: $<$ https://periodicos.ufsc.br/index.php/eb/article/view/15182924.2011v16n31p25/19441>. Acesso em: 24.07.2015.

ALMEIJA JÚNIOR, Francisco de Almeida, SANTOS NETO, João Arlindo. Mediação da informação e a Organização do Conhecimento: interrelações. Informação \& Informação. Londrina, v. 19, n. 2, p. 98-116, maio/ago 2014. Disponível em:

$<$ http://www.uel.br/revistas/uel/index.php/informacao/article/view/16716/pdf 25> . Acesso em: 24.07.15.

AQUINO, Idalécio J.; CARLAN, Eliana; BRASCHER, Marisa B. Princípios classificatórios para a construção de taxonomias. PontodeAcesso, v. 3, n. 3, p. 196-215, 2009. Disponivel em:<http://www.portalseer.ufba.br/index.php/revistaici/article/viewFile/3626/274 4>. Acesso em: 24.07.15.

ARANALDE, Michel Maya. Reflexões sobre os sistemas categorias de Aristóteles, Kant e Ranganathan. Ciência da Informação. Brasília, v. 38, n. 1, p. 86-108, jan/abr 2009. Disponível em: $<$ http://revista.ibict.br/index.php/ciinf/article/view/1056/1313>. Acesso em 24.07.15. 
ARRUDA, Rosângela Galon. Unidades de informação e sustentabilidade: requisitos para organizações do conhecimento: o caso Embrapa. RBBD. Revista Brasileira de Biblioteconomia e Documentação, v. 5, n. 1/2, p. 2841, 2010. Disponível em: <http://rbbd.febab.org.br/rbbd/article/view/146/153 $>$. Acesso em 24.07.15.

ASSIS, Juliana de; MOURA, Maria Aparecida. Folksonomia: a linguagem das tags. Encontros Bibli. Florianópolis, v. 18, n. 36, p. 85-106, jan/abr 2013. Disponível em: <https://periodicos.ufsc.br/index.php/eb/article/view/15182924.2013v18n36p85/24523>. Acesso em: 24.07.15.

BARACHO, Renata Maria Abrantes, et. al. O caminhar da Ciência da Informação e o XV Encontro Nacional de Pesquisa em Ciência da Informação. Perspectivas em Gestão \& Conhecimento, v. 4, Número Especial, p. 198211, out. 2014. Disponível em:

$<$ http://www.biblionline.ufpb.br/ojs/index.php/pgc/article/viewFile/21183/11758>. Acesso em: 24.07.15.

BARRETO, Aldo de Albuquerque. As tecnoutopias do saber: redes interligando o conhecimento. 2005. DataGramaZero-Revista de Ciência da Informação, v. 6, n. 6, 2005. Disponível em: <http://www.dgz.org.br/dez05/Art 01.htm>. Acesso em: 24.07.15.

BARROS, Camila Monteiro de; CAFÉ, Lígia Maria Arruda; SILVA, Edna Lucia. Mediação do conhecimento para o acesso à informação: reflexão baseada em uma perspectiva sociológica da ciência da informação. Ciência da Informação. Brasília. v. 40, n. 3, p. 468-477, set/dez 2011. Disponível em: $<$ http://revista.ibict.br/index.php/ciinf/article/view/2041/1442>. Acesso em 24.07.15.

BENINE, Fabiana; ZANAGA, Mariângela Pisoni. Organização da informação em portais de bibliotecas universitárias. Revista ACB: Biblioteconomia em Santa Catarina, Florianópolis, v. 14, n. 2, p. 451-467, 2009. Disponível em: $<$ http://www.brapci.inf.br/ repositorio/2010/06/pdf 5b83e70347 0011022.pdf >. Acesso: 24.07.15.

BRAZ, Márcia Ivo; PINHO, Fabio Assis. Dispositivos de memória para informação jurídica: análise de procedimentos de indexação. InCid. Ribeirão Preto, v. 4, n. 1, p. 87-106, jan/jun 2013. Disponível em: $<$ http://www.revistas.usp.br/incid/article/view/59103/62102>. Acesso em: 24.07.15.

BUFREM, Leilah Santiago. Levantando significações para significantes: da gestão do conhecimento a organização do saber. Encontros Bibli. Florianópolis, n. esp., p. 1-10, 1ํs sem 2004. Disponível em: 
$<$ https://periodicos.ufsc.br/index.php/eb/article/view/15182924.2004v9nesp1p1/5277>. Acesso em: 24.07.15.

BUFREM, Leilah Santiago; BREDA, Sônia Maria. Presença da lógica no domínio da organização do conhecimento: aspectos interdisciplinares no currículo do ensino superior. Perspect. ciênc. inf., Belo Horizonte , v. 16, n. 1, p. 185-194, 2011. Disponível em:

$<$ http://www.scielo.br/pdf/pci/v16n1/a11v16n1>. Acesso em: 24.07.15.

BUFREM, Leilah Santiago; SILVA, Helena de Fátima Nunes; BREDA, Sônia Maria. Contribuições teóricas para uma revisão dos princípios e práticas da representação do conhecimento. ETD. Campinas, v. 7, n. 1, p. 28-38, dez. 2005. Disponível em:

$<$ https://www.fe.unicamp.br/revistas/ged/etd/article/view/1833/1675>. Acesso em: 24.07.15.

CAFÉ, Lígia Maria Arruda; BARROS, Camila Monteiro de; FONSECA, Manuela Soares da. Organização do conhecimento: uma análise conceitual nos anais do ENANCIB. Em Questão. Porto Alegre, v. 20, n. 1, p. 86-112, jan/jun 2014. Disponível em: $<$ http://www.seer.ufrgs.br/index.php/EmQuestao/article/view/42696/32986>. Acesso em: 24.07.2015.

CAFÉ, Ligia Maria Arruda; BRÄSCHER, Marisa. Organização da informação e bibliometria. Encontros Bibli. Florianópolis, n. esp., p. 54-75, 1ํㅗ sem 2008. Disponível em: < https://periodicos.ufsc.br/index.php/eb/article/view/15182924.2008v13nesp1p54/1032>. Acesso em: 24.07.15.

CAFÉ, Lígia; BRÄSCHER, Marisa. Organização do Conhecimento: teorias semânticas como base para estudo e representação de conceitos. Informação \& Informação. Londrina, v. 16, n. 3, p. 25-51, jan/jun 2011. Disponível em: <http://www.uel.br/revistas/uel/index.php/informacao/article/view/10388/9282>. Acesso em: 24.07.15.

CAMPOS, Maria Luiza de A.; GOMES, Hagar Espanha; OLIVEIRA, Laura de L. As categorias de Ranganathan na Organização dos conteúdos de um portal científico. DataGramaZero-Revista de Ciência da Informação, v. 14, n. 3 , 2013. Disponível em: <http://www.dgz.org.br/jun13/Art 01.htm>. Acesso em: 24.07.15.

CAMPOS, Maria Luiza de Almeida. Modelização de Domínios de Conhecimento: uma investigação de princípios fundamentais. Ciência da Informação. Brasília, v. 33, n. 1, p. 22-32, jan/abr 2004. Disponível em: $<$ http://revista.ibict.br/ciinf/index.php/ciinf/article/view/56/53>. Acesso em: 24.07.15. 
CARVALHO, João Álvaro. Tecnologias e sistemas de informação: uma área científica orientada às necessidades de conhecimento dos profissionais envolvidos na contínua transformação das organizações através das tecnologias da informação. Encontros Bibli. Florianópolis, n. esp., p. 1-25, 2oㅜ sem. 2010. Disponível em:

$<$ https://periodicos.ufsc.br/index.php/eb/article/view/15182924.2010v15nesp2p1/15759>. Acesso em: 24.07.15.

CAVALCANTI, Débora Andrade; NASSIF, Mônica Erichsen. Diretrizes para uma metodologia de modelagem da informação na Câmara dos Deputados. Informação \& Informação. Londrina, v. 19, n. 3, p. 125-149, set/dez 2014. Disponível em:

<http://www.uel.br/revistas/uel/index.php/informacao/article/view/15927/pdf 35> . Acesso em: 24.07.15.

CERVANTES, Brigida Maria Nogueira. Resumos: Teses e Dissertações. Informação \& Informação. Londrina, v. 17, n. 1, p. 184-192, jan/jun 2011. Disponível em:

$<$ http://www.uel.br/revistas/uel/index.php/informacao/article/view/13125/11380>. Acesso em: 24.07.15.

COELHO, Kátia Cardoso; ALMEIDA, Maurício Barcellos. Aquisição de conhecimento para construção de ontologias: uma proposta de roteiro metodológico aplicado ao contexto da hematologia. Encontros Bibli. Florianópolis, v. 17, n. 35, p. 47-74, set/dez 2012. Disponível em: $<$ https://periodicos.ufsc.br/index.php/eb/article/view/15182924.2012v17n35p47/23583>. Acesso em: 24.07.15.

CORDENSONSI, Andre Zanki; FLORES, Daniel; FERREIRA, Rogério Rocha. Análise da aplicação do software SEPIADES para um acervo fotográfico. Informação \& Informação. Londrina, v. 15, n. 1, p. 129-146, jul/jun 2010. Disponível em: $<$ http://www.uel.br/revistas/uel/index.php/informacao/article/view/5024/5883 >. Acesso em: 24.07.15.

CORREA, Renato Fernandes; VIEIRA, Jessica Monique de Lira. Representações visuais para recuperação de informação na BDTD-UFPE. Perspectiva em Ciência da Informação. João Pessoa, v. 18, n. 4, p. 18-34, out/dez 2013. Disponível em: <http://www.scielo.br/pdf/pci/v18n4/03.pdf>. Acesso em: 24.07.15.

D'ANDRÉA, Carlos Frederico de Brito. Estratégias de produção e organização de informação na web: conceitos para a análise de documentos na internet. Ciência da Informação. Brasília, v. 35, n. 3, p. 39/44, set/dez 2006. Disponível 
em: <http://revista.ibict.br/index.php/ciinf/article/view/708/1613>. Acesso em: 24.07.15.

D'ANDRÉA, Carlos Frederico de Brito. Estratégias de produção e organização de informação na web: conceitos para a análise de documentos na internet. Ciência da Informação. Brasília, v. 35, n. 3, p. 39/44, set/dez 2006. Disponível em: $<$ http://revista.ibict.br/index.php/ciinf/article/view/708/1613>. Acesso em: 24.07.15.

DA GRAÇA SIMÕES, Maria; V DE FREITAS, M. Cristina. A Classificação em Arquivos e em Bibliotecas à Luz da Teoria da Classificação: pontos de convergência e de divergência. PontodeAcesso, v. 7, n. 1, p. 81-115, 2013. Disponível em: $<$ https://dspace.uevora.pt/rdpc/bitstream/10174/11833/1/Simoes Freitas PA 2 013.pdf >. Acesso em 24.07.15.

DA SILVA MEDEIROS, Jackson. A CONSTRUÇÃO DO CONCEITO: APROXIMAÇÕES COMPLEMENTARES ENTRE A ANÁLISE DE MICHEL FOUCAULT E INGETRAUT DAHLBERG. Revista ACB: Biblioteconomia em Santa Catarina, v. 15, n. 2, p. 41-53, 2010. Disponível em: $<$ https://chasqueweb.ufrgs.br/ jacksonmedeiros/pubs/2010 foucault dahlberg acb.pdf>. Acesso em: 24.07.15.

DE ABREU, Joel Gomes; MONTEIRO, Silvana Drumond. Matrizes da linguagem e a organização virtual do conhecimento. Ciência da Informação. Brasília, v. 39, n. 2, p. 9-26, maio/ago 2010. Disponível em: $<$ http://revista.ibict.br/ciinf/index.php/ciinf/article/view/1788/1363>. Acesso em: 24.07.15.

DE FREITAS, Lígia Dias. Tipos, organização e visibilidade de informações em páginas iniciais de websites de universidades brasileiras. $\mathbf{R D B C l}$, v. 11, n. 2, p. 176-196, 2013. Disponível em:

$<$ http://polaris.bc.unicamp.br/seer/ojs/index.php/rbci/article/viewFile/585/pdf>. Acesso em: 24.07.15.

DE LARA, Marilda Lopes Ginez. Novas relações entre Terminologia e Ciência da Informação na perspectiva de um conceito contemporâneo da informação. Revista de Ciência da Informação, v.7, n. 4, 2006. Disponível em: $<$ http://www.dgz.org.br/ago06/Art 02.htm>. Acesso em: 24.07.15.

DE MELO, Fábio José Dantas. Da Percepção à Recuperação da Informação. Revista Ibero-Americana de Ciência da Informação, v. 4, n. 2, 2012. Disponível em:<http://periodicos.unb.br/index.php/RICl/article/viewArticle/6210 >. Acesso em: 24.07.15. 
DE OLIVEIRA SOLANO, Viviane; ROCHA, Janicy Aparecida Pereira. O Card Sorting no ensino de biblioteconomia: uma experiência em sala de aula.Revista Digital de Biblioteconomia e Ciência da Informação, v. 13, n. 2, p. 404-417, 2015. Disponível em: <http://periodicos.sbu.unicamp.br/ojs/index.php/rdbci/article/view/8635040>. Acesso em: 24.07.15.

DELAZARI, Ana Maria; FACHIN, Gleisy Regina Bóries; ALARCON, Orestes Estevam. Sistemas de classificação facetados e tesauros: instrumentos para a organização do conhecimento. Ciência da Informação. Brasília, v. 33, n. 2, p. 161-171, maio/ago 2004. Disponível em:

<http://revista.ibict.br/index.php/ciinf/article/view/88/82>. Acesso em: 24.07.15.

DO ESPÍRITO SANTO, Silvia Maria. Os "corredores do café" como mediação do objeto cognitivo para a Ciência da Informação. 2009. DataGramaZeroRevista de Ciência da Informação, v. 10, n. 4, 2009. Disponível em: <http://www.dgz.org.br/ago09/Art 02.htm>. Acesso em: 24.07.15

DZIEKANIAK, Gisele Vasconcelos. Organização da informação e a comunicação científica: implicações para os profissionais e usuários da informação. Em Questão. Porto Alegre, v. 16, n. 1, p. 45-59, jan/jun 2010. Disponível em: <http://seer.ufrgs.br/index.php/EmQuestao/article/view/11434/8761>. Acesso em: 24.07.15.

DZIEKANIAK, Gisele Vasconcelos; KIRINUS, Josiane Boeira. Web semântica. Encontros Bibli. Florianópolis, n. 18, p. 20-39, ㅡ sem 2004. Disponível em: $<$ https://periodicos.ufsc.br/index.php/eb/article/view/15182924.2004v9nesp1p1/5277>. Acesso em: 24.07.15.

ELUAN, Andrenizia Aquino Eluan; MOMM, Christiane Fabíola; NASCIMENTO, Jucima Almeida. A sistemática do uso de fontes de informação para a pesquisa científica. I\&S. João Pessoa, v. 18, n. 2, p. 111-119, maio/ago 2008. Disponível em: <http://www.ies.ufpb.br/ojs/index.php/ies/article/view/1761/2124>. Acesso em: 24.07.15.

GOMES, Hagar Espanha; DE ALMEIDA CAMPOS, Maria Luiza; DOS SANTOS GUIMARÃES, Ludmila. Organização da Informação e Terminologia: a abordagem onomasiológica. DataGramaZero-Revista de Ciência da Informação, v. 11, n. 5, 2010. Disponível em: < http://www.dgz.org.br/out10/Art 03.htm >. Acesso em: 24.07.15.

GRACIOSO, Luciana de Souza. Parâmetros teóricos para elaboração de instrumentos pragmáticos de representação e organização da informação na web: considerações preliminares sobre uma possível proposta metodológica. 
InCid. Ribeirão Preto, v. 1, n. 1, p. 138-158, 2010. Disponível em: < http://www.revistas.usp.br/incid/article/view/42310/45981>. Acesso em: 24.07.15.

GUEDES, Roger de Miranda; MOURA, Maria Aparecida, DIAS, Eduardo José Wense. Indexação Social e Pensamento Dialógico: reflexões teóricas. Informação \& Informação. Londrina, v. 16, n. 3, p. 40-59, jan/jun 2011. Disponível em:

<http://www.uel.br/revistas/uel/index.php/informacao/article/view/10477/10642>. Acesso em: 24.07.15.

GUIMARÃES, José Augusto Chaves. A dimensão teórica do tratamento temático da informação e suas interlocuções com o universo científico da International Society for Knowledge Organization (ISKO. Revista Iberoamericana de Ciência da Informação (RICI), v. 1, n. 1, p. 77-99, 2008. Disponível em: <http://eprints.rclis.org/19114/>. Acesso em: 24.07.15.

GUIMARÃES, José Augusto Chaves; DE SALES, Rodrigo; GRÁCIO, Maria Cláudia Cabrini. A dimensão interdisciplinar da análise documental nos contextos brasileiro e espanhol no âmbito da organização do conhecimento.

DataGramaZero-Revista de Ciência da Informação, v. 13, n. 6, 2012. Disponível em: <http://www.dgz.org.br/dez12/Art 07.htm>. Acesso em: 24.07.15.

GUIMARÃES, José Augusto Chaves; SALES, Rodrigo de. Análise documental: concepções do universo acadêmico brasileiro em Ciência da Informação. DataGramaZero-Revista de Ciência da Informação v. 11, n. 1, 2010. Disponível em: <http://www.dgz.org.br/fev10/Art 02.htm>. Acesso em: 24.07.15.

JÚNIOR, Rogério Henrique de Araújo; ALBUQUERQUE, Sérgio Farias de. Morfologia para representação das necessidades de informação. Em Questão. Porto Alegre, v. 20, n. 2, p. 166-187, jul/dez 2014. Disponível em: $<$ http://seer.ufrgs.br/index.php/EmQuestao/article/view/42855/32118>. Acesso em: 24.07.15.

KOBASHI, Nair Yumiko. Fundamentos semânticos e pragmáticos da construção de instrumentos de representação de informação. Revista de Ciência da Informação, v. 8, n. 6, 2007. Disponível em: <http://www.dgz.org.br/dez07/Art 01.htm>. Acesso em: 24.07.15.

KOBASHI, Nair Yumiko; FRANCELIN, Marivalde Moacir. Conceitos, Categorias e Organização do Conhecimento. Informação \& Informação. Londrina, v. 16, n. 3, p. 1-24, jan/jun 2011. Disponível em: 
<http://www.uel.br/revistas/uel/index.php/informacao/article/view/10390/9281>. Acesso em: 24.07.15.

LARA, Marilda Lopes Ginez. Propostas de tipologias de KOS: uma análise das referências de formas dominantes de organização do conhecimento.

Encontros Bibli. Florianópolis, v. 20, n. esp. 1, p. 89-107, fev. 2015.

Disponível em: <https://periodicos.ufsc.br/index.php/eb/article/view/15182924.2015v20nesp1p89/28637>. Acesso em: 24.07.15.

LIMA, Gercina. Modelo hipertextual-MHTX: um modelo para organização hipertextual de documentos. Revista de Ciência da Informação, v.8, n. 4, 2007. Disponível em: <http://www.dgz.org.br/ago06/Art 03.htm>. Acesso em: 24.07.15.

LOURENÇO, Cíntia Azevedo. Metadados - O grande desafio na organização da web. I\&S. João Pessoa, v. 17, n. 1, p. 65-72, jan/abr 2007. Disponível em: $<$ http://www.ies.ufpb.br/ojs/index.php/ies/article/view/466/1466>. Acesso em: 24.07.15.

MARCONDES, Carlos Henrique. Organização e Representação do Conhecimento Científico em Ambiente Web: do formato textual linear aos artigos semânticos. PontodeAcesso, v. 7, n. 1, p. 7-41, 2013. Disponível em: $<$ http://www.portalseer.ufba.br/index.php/revistaici/article/viewFile/8134/5806>. Acesso em: 24.07.15.

MARCONDES, Carlos Henrique. Representação e economia da informação. Ciência da Informação. Brasília, v. 30, n. 1, p. 61-70, jan/abr 2001. Disponível em:

$<$ http://revista.ibict.br/cienciadainformacao/index.php/ciinf/article/view/225/200>. Acesso em: 24.07.15.

MARIA DE FÁTIMA, G. M.; LENZI, Lívia Aparecida Ferreira. Terminologia e documentação: a relação solidária das organizações do conhecimento e da informação no domínio da inovação tecnológica. 2006. Revista de Ciência da Informação, v.7, n. 4, 2006. Disponível em:

$<$ http://www.dgz.org.br/ago06/Art 03.htm>. Acesso em: 24.07.15.

MOLINA, Letícia Gorri; LUNARDELLI, Rosane Suely Alvares. O Prontuário do Paciente e os Pressupostos Arquivísticos: estreitas e profícuas interlocuções. Informação \& Informação. Londrina, v. 15, n. 1, p. 68-84, jul/jun 2010. Disponível em: $<$ http://www.uel.br/revistas/uel/index.php/informacao/article/view/4764/5879 $>$. Acesso em: 24.07.15. 
MONTEIRO, Silvana Drumond. A organização virtual do conhecimento no ciberespaço. DataGramaZero-Revista de Ciência da Informação, v. 4, n. 6, p. 1-20, 2003. Disponível em: <http://www.dgz.org.br/dez03/Art 05.htm>. Acesso em: 24.07.15.

MONTEIRO, Silvana Drumond. O ciberespaço e os mecanismos de busca: novas máquinas semióticas. Ciência da Informação. Brasília, v. 35, n. 1, p. 31-38, jan/abr 2006. Disponível em:

$<$ http://revista.ibict.br/ciinf/index.php/ciinf/article/view/663/577>. Acesso em: 24.07.15.

MONTEIRO, Silvana Drumond; ABREU, JG de. O pós-moderno e a organização do conhecimento no ciberespaço: agenciamentos maquínicos DataGramaZero-Revista de Ciência da Informação, v. 10, n. 6, p. 1-9. 2009. Disponível em: <http://www.dgz.org.br/dez09/Art 05.htm>. Acesso em: 24.07.15.

MONTEIRO, Silvana Drumond; GIRALDES, Maria Júlia Carneiro. Aspectos lógico-filosóficos da organização do conhecimento na esfera da Ciência da Informação. I\&S. João Pessoa, v. 18, n. 3, p. 13-27, set/dez 2008. Disponível em: <http://www.ies.ufpb.br/ojs/index.php/ies/article/view/1775/2269>. Acesso em: 24.07.15.

MOREIRA, Manoel Palhares; MOURA, Maria Aparecida. Construindo tesauros a partir de tesauros existentes: a experiência do TCI-Tesauro em Ciência da Informação. 2006. Revista de Ciência da Informação, v.7, n. 4, 2006. Disponível em: <http://www.dgz.org.br/ago06/Art 01.htm>. Acesso em: 24.07.15.

MOREIRA, Walter. Provocações deleuzeanas para as linguagens documentárias. InCid. Ribeirão Preto, v. 1, n. 2, p. 21-36, jul/dez 2010. Disponível em: <http://www.revistas.usp.br/incid/article/view/42317/45988>. Acesso em: 24.07.15.

MOSTAFA, Solange Puntel; DA NOVA CRUZ, Denise Viuniski. Patchwork como princípio de produção e organização do conhecimento. DataGramaZeroRevista de Ciência da Informação, v. 12, n. 1, 2012. Disponivel em: < http://www.dgz.org.br/fev11/Art 02.htm >. Acesso em: 24.07.15

MOURA, Maria. Folksonomias, redes sociais e a formação para o tagging literacy: desafios para a organização da informação em ambientes colaborativos virtuais. Informação \& Informação. Londrina, v. 14, n. esp., p. 25-45, 2009. Disponível em: < 
http://www.uel.br/revistas/uel/index.php/informacao/article/view/2196/3217>. Acesso em: 24.07.15.

NEGREIROS, Leandro R. Uma compreensão dos fundos arquivísticos sob o enfoque da análise de domínio. Informação \& Informação. Londrina, v. 13, n. 2, p. 79-95, jul/dez 2008. Disponível em: $<$ http://www.uel.br/revistas/uel/index.php/informacao/article/view/1818/1678>. Acesso em: 24.07.15.

OBREGON, Rosane de Fátima A; DZIEKANIAK Gisele Vasconcelos, VANZIN, Tarcisio. A emergência da gestão do conhecimento para ancorar a excelência organizacional. Perspectivas em Gestão \& Conhecimento, v. 2, n. 1, p. 218227, jan./jun. 2012. Disponível em:

$<$ http://periodicos.ufpb.br/ojs2/index.php/pgc > Acesso em: 24.07.15.

OLIVEIRA, Dalgiza Andrade; ARAUJO, Ronaldo Ferreira de. Construção de linguagens documentárias em sistemas de recuperação da informação: a importância da garantia do usuário. Encontro Bibli. Florianópolis, v. 17, n. 34, p. 17-30, maio/ago 2012. Disponível em: $<$ https://periodicos.ufsc.br/index.php/eb/article/view/15182924.2012v17n34p17/22620>. Acesso em: 24.07.15.

OLIVEIRA, Heloá Cristina Camargo de. DISCUSSÕES HIPERMODERNAS. PontodeAcesso, v. 3, n. 3, p. 258-269, 2009. Disponível em: $<$ http://www.portalseer.ufba.br/index.php/revistaici/article/viewPDFInterstitial/36 20/2747>. Acesso em: 24.07.15.

ORRICO, Evelyn Goyannes Dill; OLIVEIRA, CIC de. A representação metafórica nos caminhos do conhecimento em tempos de comunicação globalizada DataGramaZero-Revista de Ciência da Informação, v. 6, n. 5, 2005. Disponível em: <http://www.dgz.org.br/out05/Art 04.htm>. Acesso em: 24.07.15.

ORTEGA, Cristina Dotta. Contexto de desenvolvimento da Organização da Informação, com enfoque para a Catalogação, na Escola de Ciência da Informação da UFMG.Perspect. ciênc. inf., Belo Horizonte, v. 18, n. 2, p. 182-215, jun. 2013. Disponível em $<$ http://www.scielo.br/scielo.php?script=sci arttext\&pid=S141399362013000200012\&lng=pt\&nrm=iso $>$. Acesso em 24.07.15.

ORTEGA, Cristina Dotta. Relações históricas entre biblioteconomia, documentação e ciência da informação. DataGramaZero-Revista de Ciência da Informação, v. 5, n. 5, 2004.Disponível em: $<$ http://www.dgz.org.br/out04/Art 03.htm>. Acesso em: 24.07.5. 
PADILHA, Renata Cardozo; CAFÉ, Lígia Maria Arruda. Organização de acervo fotográfico histórico: proposta de descrição. InCid. Ribeirão Preto, v. 5, n. 1, p. 90-111, mar/ago 2014. Disponível em:

$<$ http://www.revistas.usp.br/incid/article/view/73527/pdf 24>. Acesso em:

24.07.15.

PONTES, Flavio Vieira; LIMA, Gercina Ângela Borém de Oliveira. A organização do conhecimento em ambientes digitais: aplicação da teoria da classificação facetada. Perspect. ciênc. inf., Belo Horizonte, v. 17, n. 4, p. 18-40, 2012. Disponível em: <http://www.scielo.br/pdf/pci/v17n4/03.pdf>. Acesso em: 24.07.15.

PORÉM, Maria Eugênia; GUARALDO, Tamara de Souza Brandão. Informação, conhecimento e comunicação em organizações do conhecimento.

DataGramaZero-Revista de Ciência da Informação, v. 13, n. 1, 2013. Disponível em: < http://www.dgz.org.br/fev12/Art 06.htm >. Acesso em: 24.07.15.

RAMALHO, Rogério Aparecido Sá; OUCHI, Marcos Teruo. Tecnologias Semânticas: Novas Perspectivas para a Representação de Recursos Informacionais. Informação \& Informação. Londrina, v. 16, n. 3, p. 60-75, jan/jun 2011. Disponível em:

<http://www.uel.br/revistas/uel/index.php/informacao/article/view/9829/10643>.

Acesso em: 24.07.15.

RAMOS, Lúcia Veronica Costa; FUJINO, Asa. Redes de informação científica e os desafios para popularização da ciência: estudo de caso na Rede SIEO Sistema de Informação Especializado na Área de Odontologia. Informação \& Informação. Londrina, v. 18, n. 1, p. 33-58, jan/abr 2013. Disponível em: $<$ http://www.uel.br/revistas/uel/index.php/informacao/article/view/11628/pdf>. Acesso em: 24.07.15.

Referência: KOBASHI, Nair Yumiko; SANTOS, Raimundo Nonato Macedo dos. Arqueologia do trabalho imaterial: uma aplicação bibliométrica à análise de dissertações e teses. Encontros Bibli. Florianópolis, n. esp. 1, p. 106-115, 1ㅇ sem 2008. Disponível em:

$<$ https://periodicos.ufsc.br/index.php/eb/article/view/1518-

2924.2008v13nesp1p106/868>. Acesso em: 24.07.15.

RIBEIRO, Fabiano Ferrari; MONTEIRO, Silvana Drumond. Arquitetura da Informação em sites de Pró-Reitorias de Graduação: um enfoque nas Instituições Estaduais de Ensino Superior do Paraná. Informação \& Informação. Londrina, v. 17, n. 3, p. 125-164, set/dez 2012. Disponível em: $<$ http://www.uel.br/revistas/uel/index.php/informacao/article/view/13104/pdf $>$. Acesso em: 24.07.15. 
ROBREDO, Jaime. Filosofia e Informação? Reflexões. Revista IberoAmericana de Ciência da Informação, v. 4, n. 2, 2012. Disponível em: $<$ http://periodicos.unb.br/index.php/RICl/article/viewArticle/6207>. Acesso em: 24.07.15.

ROBREDO, Jaime. Sobre arquitetura da informação. Revista IberoAmericana de Ciência da Informação, v. 1, n. 2, 2010. Disponível em: <http://periodicos.unb.br/index.php/RICl/article/viewArticle/808>. Acesso em: 24.07.15.

RODRIGUES, Anderson Luiz Cardoso. A Complexidade da cultura amazônica e seu reflexo para a organização e representação da informação. AtoZ: novas práticas em informação e conhecimento. Curitiba, v. 1, n. 2, p. 10-25, jan/dez 2012. Disponível em: <http://dx.doi.org/10.5380/atoz.v1i2.41309>. Acesso em: 24.07.15.

RODRIGUES, Anderson Luiz Cardoso. A seleção conceitual na organização de domínios de conhecimento nas ciências humanas e sociais: o caso da cultura.Perspect. ciênc. inf., Belo Horizonte, v. 16, n. 2, p. 131-152, jun. 2011. Disponível em $<$ http://www.scielo.br/scielo.php?script=sci arttext\&pid=S141399362011000200009\&lng=pt\&nrm=iso>. Acesso em 24.07.15

ROQUETA, Mario Barité. Sistemas de Organização do Conhecimento: uma tipologia atualizada. Informação \& Informação. Londrina, v. 16, n. 3, p. 122139, jan/jun 2011. Disponível em:

<http://www.uel.br/revistas/uel/index.php/informacao/article/view/9952/9286>. Acesso em: 24.07.15.

SABBAG, Deise Maria Antonio. A Organização da Informação de Julius Kaiser - Resenha. InCid. Ribeirão Preto, v. 5, n. 1, p. 173-177, mar/ago 2014. Disponível em: <http://www.revistas.usp.br/incid/article/view/78125/pdf 26>. Acesso em: 24.07.15.

SALES, Luana Farias; CAMPOS, Maria Luiza de Almeida; GOMES, Hagar Espanha. Ontologias de domínio: um estudo das relações conceituais. Perspect. ciênc. inf., Belo Horizonte, v. 13, n. 2, p. 62-76, Ago. 2008. Disponível em:

$<$ http://www.scielo.br/scielo.php?script=sci arttext\&pid=S141399362008000200006\&lng=en\&nrm=iso >. Acesso em: 24.07.15.

SAN SEGUNDO, Rosa; CODINA-CANET, María Adelina. Incidencia de aspectos historiográficos en la organización de los saberes en la universidad. Brazilian Journal of Information Science. Marília. v. 8, n. 1, 2014. Disponível 
em:

<http://www2.marilia.unesp.br/revistas/index.php/bjis/article/view/4244/3084>. Acesso em: 27.07.15.

SANTA ANNA, Jorge. A ( $r$ ) evolução digital e os dilemas para a catalogação: os cibertecários em atuação. Revista Digital de Biblioteconomia e Ciência da Informação, v. 13, n. 2, p. 312-328, 2015. Dispoível em:<http://periodicos.bc.unicamp.br/ojs/index.php/rdbci/article/view/8634632>. Acesso em: 24.07.15.

SANTOS, Hercules Pimenta. Etiquetagem e folksonomia: o usuário e sua motivação para organizar e compartilhar informação na Web 2.0.Perspectivas em Ciência da Informação, v. 18, n. 2, p. 91-104, 2013. Disponível em: $<$ http://www.scielo.br/pdf/pci/v18n2/07.pdf >. Acesso em:24.07.15.

SCHONS, Claudio Henrique. O volume de informações na Internet e sua desorganização: reflexões e perspectivas. Informação \& Informação. Londrina, v. 12, n. 1, p. 1-24, jan/jun 2007. Disponível em: <http://www.uel.br/revistas/uel/index.php/informacao/article/view/1748/1497>. Acesso em: 24.07.15.

SMIRAGLIA, Richard P. Ethics in Knowledge Organization: Two Conferences Point to a New Core in the Domain. Encontros Bibli. Florianópolis, v. 20, n. esp. 1, p. 1-18, 2015. Disponível em: $<$ https://periodicos.ufsc.br/index.php/eb/article/view/15182924.2015v20nesp1p1/28632>. Acesso em: 24.07.15.

SOARES, Maria Sueny Barbosa; MARTINS, Mariana Thamires; FRANCELIN, Marivalde Moacir. Pluralismo lógico e epistemografia interativa como ferramentas desclassificadoras do conhecimento. RDBCI, v. 11, n. 1, p. 55-71, 2013. Disponível em:

$<$ http://143.106.108.14/seer/ojs/index.php/rbci/article/viewFile/571/pdf >. Acesso em: 24.07.15.

SOUZA, Rosali Fernandez de. Organização e representação de áreas do conhecimento em ciência e tecnologia: princípios de agregação em grandes áreas segundo diferentes contextos de produção e uso de informação.

Encontros Bibli. Florianópolis, n. esp., p. 27-41, 1ํsem 2006. Disponível em: $<$ https://periodicos.ufsc.br/index.php/eb/article/view/15182924.2006v11nesp1p27/384>. Acesso em: 24.07.15.

Souza, Roseli Fernandez de. Áreas do Conhecimento. DataGramaZeroRevista de Ciência da Informação, v. 5, n. 2, 2004. Disponível em: <http://www.dgz.org.br/abr04/Art 02.htm>. Acesso em: 24.07.15. 
VICTORINO, M. C.; BRÄSCHER, Marisa. Organização da informação e do conhecimento, engenharia de software e arquitetura orientada a serviços: uma abordagem holística para o desenvolvimento de sistemas de informação computadorizados. DataGramaZero-Revista de Ciência da Informação, v. 10, n. 3, 2009. Disponível em:<http://www.dgz.org.br/jun09/Art 03.htm>. Acesso em: 27.07.15.

VIGNOLI, Richele Grenge; DE ALMEIDA, Patrícia Ofélia Pereira; CATARINO, Maria Elisabete. Folksonomias como ferramenta da organização e representação da informação. $\mathbf{R D B C l , ~ v . ~ 1 2 , ~ n . ~ 2 , ~ p . ~ 1 2 0 - 1 3 5 , ~ 2 0 1 4 . ~ D i s p o n i ́ v e l ~}$ em: <http://polaris.bc.unicamp.br/seer/ojs/index.php/rbci/article/view/4066>> Acesso em: 24.07.15.

VIGNOLI, Richele Grenge; SOUTO, Diana Vilas Boas; CERVANTES, Brígida Maria Nogueira. Sistemas de organização do conhecimento com foco em ontologias e taxonomias. I\&S. João Pessoa, v. 23, n. 2, p. 59-72, maio/ago 2013. Disponível em:

$<$ http://www.ies.ufpb.br/ojs/index.php/ies/article/view/15160/9685>. Acesso em: 24.07.15.

VITAL, Luciane Paula; CAFE, Ligia. Proposta para o desenvolvimento de taxonomias em portais corporativos. Perspect. ciênc. inf., Belo Horizonte, v. 16, n. 4, p. 42-54, dez. 2011 . Disponível em $<$ http://www.scielo.br/scielo.php?script=sci arttext\&pid=S141399362011000400005\&lng=pt\&nrm=iso >. Acesso em 24.07.15

\section{Teses}

ALMEIDA, Carlos Cândido de. Peirce e a organização da informação: contribuições teóricas da semiótica e do pragmatismo. 2009. 416 f. Tese (Doutorado em Ciência da Informação ) - Programa de Pós-Graduação em Ciência da Informação, Faculdade de Filosofia e Ciências, Universidade Estadual Paulista. Marília, 2009. Disponível em: < http://hdl.handle.net/11449/103380 >. Acesso em: 22. 07. 15.

ANJOS, Liane dos. Sistemas de classificação do conhecimento na filosofia e na biblioteconomia: uma visão histórico-conceitual crítica com enfoque nos conceitos de classe, de categoria e de faceta. 2009. $290 \mathrm{f}$. Tese (Doutorado em Cultura e Informação) - Programa de Pós-Graduação em Ciência da Informação, Escola de Comunicações e Artes, Universidade de São Paulo, São Paulo, 2009. Disponível em: < 
http://www.teses.usp.br/teses/disponiveis/27/27151/tde-10112010-114437/ >. Acesso em: 22. 07. 15

COSTA, Luzia Sigoli Fernandes. Uma contribuição da teoria literária para a análise de conteúdo de imagens publicitárias do fim do século XIX e primeira metade do século XX, contemplando aspectos da natureza brasileira. 2008. 261 f. Tese (Doutorado em Ciência da Informação) Programa de Pós-Graduação em Ciência da Informação, Faculdade de Filosofia e Ciências, Universidade Estadual Paulista. Marília, 2008. Disponível em: <http://hdl.handle.net/11449/103374>. Acesso em: 22. 07. 15.

DAL'EVEDOVE, Paula Regina. O tratamento temático da informação em abordagem sociocultural: diretrizes para definição de política de indexação em bibliotecas universitárias. 2014. 266 f. Tese (Doutorado em Ciência da Informação) - Programa de Pós-Graduação em Ciência da Informação, Faculdade de Filosofia e Ciências, Universidade Estadual Paulista. Marília, 2014. Disponível em: <http://hdl.handle.net/11449/110385>. Acesso em: 22. 07. 15.

ESPÍRITO SANTO, Silvia Maria do. O colecionador público documentalista: museu histórico e de ordem geral Plínio Travassos dos Santos de Ribeirão Preto. 2009. 206 f. Tese (Doutorado em Ciência da Informação) - Programa de Pós-Graduação em Ciência da Informação, Faculdade de Filosofia e Ciências, Universidade Estadual Paulista. Marília, 2009. Disponível em: $<$ http://hdl.handle.net/11449/100795>. Acesso em: 22. 07. 15.

FURLANETO NETO, Mário. O assunto do e-mail como indício de fraude: contribuições da organização da informação para a prevenção criminal. 2008. 262 f. Tese (doutorado) - Universidade Estadual Paulista, faculdade de Filosofia e Ciências, 2008.2 Disponível em: <http://hdl.handle.net/11449/103390>. Acesso em: 22.07.15.

MARTINS, Gracy Kelli. Institucionalização cognitiva e social da Organização e Representação do Conhecimento na Ciência da Informação no Brasil. 2014. 184 f. Tese (Doutorado em Ciência da Informação) Programa de Pós-Graduação em Ciência da Informação, Faculdade de Filosofia e Ciências, Universidade Estadual Paulista. Marília, 2014. Disponível em: $<$ http://hdl.handle.net/11449/114036>. Acesso em: 22. 07. 15

MILANI, Suellen Oliveira. Bias na Representação de Assunto: Uma Discussão de Oposições Binárias nos Functional Requirements for Subject Authority Data (FRSAD). 2014. 134 f. Tese (Doutorado em Ciência da Informação) - Programa de Pós-Graduação em Ciência da Informação, Faculdade de Filosofia e Ciências, Universidade Estadual Paulista. Marília, 
2014. Disponível em: < http://hdl.handle.net/11449/110388 >. Acesso em: 22. 07.15.

ORTEGA, Cristina Dotta. Os registros de informação dos sistemas documentários: uma discussão no âmbito da Representação Descritiva. 2009. 250 f. Tese (Doutorado em Cultura e Informação) - Programa de PósGraduação em Ciência da Informação, Escola de Comunicações e Artes, Universidade de São Paulo. São Paulo, 2009. Disponível em: $<$ http://www.teses.usp.br/teses/disponiveis/27/27151/tde-21092009-211824/>. Acesso em: 22. 07. 15

RAMALHO, Rogério Aparecido Sá. Desenvolvimento e utilização de ontologias em bibliotecas digitais: uma proposta de aplicação. 2010.145 f. Tese (Doutorado em Ciência da Informação) - Programa de Pós-Graduação em Ciência da Informação, Faculdade de Filosofia e Ciências, Universidade Estadual Paulista. Marília, 2010. Disponível em: $<$ http://hdl.handle.net/11449/103376 >. Acesso em: 22. 07. 15.

SALES, Rodrigo de. A presença de Kaiser no Quadro Teórico do Tratamento Temático da Informação (TTI). 2012. 190 f. Tese (Doutorado em Ciência da Informação) - Programa de Pós-Graduação em Ciência da Informação, Faculdade de Filosofia e Ciências, Universidade Estadual Paulista. Marília, 2012. Disponível em: < http://hdl.handle.net/11449/103381 >. Acesso em: 22. 07. 15.

\section{Dissertações}

AGUIAR, Maria Lucinda Meirelles. Organização e disponibilização de bases de informações municipais para gestão de políticas públicas. 2006. 81 f. Dissertação (Mestrado em Cultura e Informação) - Programa de PósGraduação em Ciência da Informação, Escola de Comunicações e Artes, Universidade de São Paulo. São Paulo, 2006. Disponível em: < http://www.teses.usp.br/teses/disponiveis/27/27151/tde-11052009-160232/ >. Acesso em: 22. 07. 15.

ALMEIDA, P. O. P. d. Saúde coletiva: Organização e representação da informação sob a perspestiva das palavras-chave de artigos de periódicos científicos e a formação acadêmica de seus autores. 2014. 106 f. Dissertação (Mestrado em Ciência da Informação) - Programa de Pós-Graduação em Ciência da Informação, Centro de Educação Comunicação e Artes, Universidade Estadual de Londrina. Londrina. 2012. Disponível em: < http://www.bibliotecadigital.uel.br/document/?code=vtls000194625 $>$. Acesso em: 22. 07. 15. 
ANDRADE, Julietti de. A Linguística Documentária e a Análise de Domínio na Organização da Informação. 2010. 150 f. Dissertação (Mestrado em Cultura e Informação) - Programa de Pós-Graduação em Ciência da Informação, Escola de Comunicações e Artes, Universidade de São Paulo. São Paulo, 2010. Disponível em: < http://www.teses.usp.br/teses/disponiveis/27/27151/tde-22022011-142712>. Acesso em: 22. 07. 15.

ANDRADE, M. C. d. A interoperabilidade semântica na perspectiva da organização do conhecimento: Uma proposta para o repositório institucional da Universidade Federal do Espírito Santo. 2012. 212 f. Dissertação (Mestrado em Ciência da Informação) - Programa de Pós-Graduação em Gestão da Informação, Centro de Educação Comunicação e Artes, Universidade Estadual de Londrina. Londrina, 2012. Disponível em:

$<$ http://www.bibliotecadigital.uel.br/document/?code $=v t \mid s 000180648>$. Acesso em: 22. 07. 15

ARTENCIO, Luciane Maria. Princípios de categorização nas linguagens documentárias. 2007. 129 f. Dissertação (Mestrado em Cultura e Informação) - Programa de Pós-Graduação em Ciência da Informação, Escola de Comunicações e Artes, Universidade de São Paulo, São Paulo, 2007. Disponível em: <http://www.teses.usp.br/teses/disponiveis/27/27151/tde30052008-152640/>. Acesso em: 23.07.15.

BEMBEM, Angela Halen Claro. A Ciência da Informação e os espaços antropológicos: uma aproximação possível?. 2013. 118 f. Dissertação (Mestrado em Ciência da Informação) - Programa de Pós-Graduação em Ciência da Informação, Faculdade de Filosofia e Ciências, Universidade Estadual Paulista. Marília, 2013. Disponível em: < http://hdl.handle.net/11449/93657 >. Acesso em: 27.07.15.

BENINE, F. Organização da informação em portais de bibliotecas universitárias. 2009. 103 f. Dissertação (Mestrado em Ciência da Informação) - Pós-Graduação em Ciência da Informação, Centro de Ciências Sociais Aplicadas, Pontifícia Universidade Católica de Campinas. Campinas, 2009. Disponível em: <http://www.bibliotecadigital.puccampinas.edu.br/tde busca/arquivo. php?codArquivo $=500>$. Acesso em: 27.07.15.

BRAZ, M. I. A. Dispositivos de memória para informação jurídica: Análise de procedimentos de indexação. 2013. 190 f. Dissertação (Mestrado em Ciência da Informação) - Programa de Pós-Graduação em Ciência da Informação, Centro de Artes e Comunicação, Universidade Federal de Pernambuco. Recife, 2013. Disponível em: < http://repositorio.ufpe.br:8080/xmlui/handle/123456789/104488 >. Acesso em: 22. 07. 15. 
BRITO, F. N. N. d. Junta Comercial do Estado da Bahia: [manuscrito] disseminação da informação do registro público de empresas mercantis. 2013. 224 f. Dissertação (Mestrado em Ciência da Informação) - Programa de PósGraduação em Ciência da Informação, Instituto de Ciência da Informação, Universidade Federal da Bahia. Salvador, 2013. Disponível em: < http://www.repositorio.ufba.br/ri/handle/ri/81766 >, Acesso em: 27. 07. 15.

CAVALCANTE, Jacqueline Nunes. Análise das práticas de gestão do conhecimento: estudo de caso em uma empresa do setor calçadista da Paraíba. 2010. 177 f. Dissertação (Mestrado em Engenharia de Produção) Programa de Pós-Graduação em Engenharia de Produção, Centro de Tecnologia, Universidade Federal da Paraíba. João Pessoa, 2010. Disponível em: < http://tede.biblioteca.ufpb.br:8080/handle/tede/5287>. Acesso em: 27. 07. 15.

CICON, C. R. A organização da informação em ambiente Web: Um estudo do portal do Procon-PR. 2012. 109 f. Dissertação (Mestrado Profissional em Gestão da Informação) - Programa de Pós-Graduação em Gestão da Informação, Centro de Educação Comunicação e Artes, Universidade Estadual de Londrina. Londrina, 2011. Disponível em: < http://www.bibliotecadigital.uel.br/document/?code=vtls000181054 >. Acesso em: 27.07.15

CÓSCIA, Vera Lúcia. Análise de fotografias: Florestan Fernandes no tempo da ditadura militar. 2012. 144 f. Dissertação (Mestrado em Ciência Tecnologia e Sociedade) - Programa de Pós-Graduação em Ciência Tecnologia e Sociedade, Centro de Educação e Ciências Humanas, Universidade Federal de São Carlos. São Carlos, 2012. Disponível em: < http://www.bdtd.ufscar.br/htdocs/tedeSimplificado//tde busca/arquivo.php?codA rquivo $=6235$ > Acesso em: 22.07.15

COURA, A. d. S. Experimentos com probabilidade e estatística: Jankenpon, Monte Carlo, variáveis antropométricas. 2014. 164 f. Dissertação (Mestrado Profissional) - Programa de Pós-Graduação em Matemática em Rede Nacional, Instituto de Matemática Estatística e Computação Científica, Universidade Estadual de Campinas. Campinas, 2014. Disponível em: < http://libdigi.unicamp.br/document/?code=000940272 >. Acesso em: 22. 07. 15.

\section{DIAS, G. D. A organização temática da informação em periódicos}

científicos eletrônicos: Atribuição de palavras-chave na biblioteconomia e ciência da informação. 2012. 159 f. Dissertação (Mestrado Profissional em Gestão da Informação) - Programa de Pós-Graduação em Gestão da Informação, Centro de Educação Comunicação e Artes, Universidade Estadual de Londrina. Londrina, 2012. Disponível em: < http://www.bibliotecadigital.uel.br/document/?code $=v t l s 000180280>$. Acesso em: 27. 07. 15. 
EUCLIDES, Maria Luzinete. Representação das necessidades de informação na organização da informação: uma análise de modelos teóricos de busca. 2007. 111 f. Dissertação (Mestrado em Ciência da Informação) Programa de Pós-Graduação em Ciência da Informação, Faculdade de Filosofia e Ciências, Universidade Estadual Paulista. Marília, 2007. Disponível em: < http://hdl.handle.net/11449/936955 >. Acesso em: 27.07.15

FILHO, A. B. d. L. Organização da informação em sites de recursos humanos de universidades públicas estaduais da região sul do Brasil. 2011. 132 f. Dissertação (Mestrado Profissional em Gestão da Informação) Programa de Pós-Graduação em Gestão da Informação, Centro de Educação Comunicação e Artes, Universidade Estadual de Londrina. Londrina, 2011. Disponível em: < http://www.bibliotecadigital.uel.br/document/?code=vtls000168112 >. Acesso em: 27. 07. 15.

GALLANO, E. Representação da informação e o material didático impresso para EAD: Contribuições para sua elaboração. 2011. 78 f. Dissertação (Mestrado Profissional em Gestão da Informação) - Programa de Pós-Graduação em Gestão da Informação, Centro de Educação Comunicação e Artes, Universidade Estadual de Londrina. Londrina, 2011. Disponível em: < http://www.bibliotecadigital.uel.br/document/?code $=v t l s 000166885$ >. Acesso em: 27. 07. 15.

GARCIA, Rodrigo Moreira. Modelos de comportamento de busca de informação: contribuições para a organização da informação. 2007. 139 f. Dissertação (Mestrado em Ciência da Informação) - Programa de PósGraduação em Ciência da Informação, Faculdade de Filosofia e Ciências, Universidade Estadual Paulista. Marília, 2007. Disponível em: < http://hdl.handle.net/11449/936966 >. Acesso em: 27.07.15

GARDIN, D. d. A. O. Organização da informação nas secretarias dos setores de conhecimento da UNICENTRO: Uma proposta de fluxo de tratamento e recuperação da informação. 2011. 146 f. Dissertação (Mestrado Profissional de Gestão da Informação) - Programa de Pós-Graduação em Gestão da Informação, Centro de Educação Comunicação e Artes, Universidade Estadual de Londrina. Londrina, 2011. Disponível em: < http://www.bibliotecadigital.uel.br/document/?code=vtls000168114 >. Acesso em: 27.07.15

GONCALVES, Aline Lima. Serviço de informação sobre deficiência: desafios para organização da informação. 2010. 186 f. Dissertação (Mestrado em Cultura e Informação) - Programa de Pós-Graduação em Ciência da Informação, Escola de Comunicações e Artes, Universidade de São Paulo. São Paulo, 2010. Disponível em: < http://www.teses.usp.br/teses/disponiveis/27/27151/tde-05112010-104413/ >. Acesso em: 22. 07. 15. 
GUEDES, Emanuel Guedson Ferreira. O conceito aboutness na organização e representação do conhecimento. 2009. 90 f. Dissertação (Mestrado em Ciência da Informação) - Programa de Pós-Graduação em Ciência da Informação, Faculdade de Filosofia e Ciências, Universidade Estadual Paulista. Marília, 2009. Disponível em: < http://base.repositorio.unesp.br/handle/11449/93659 >. Acesso em: 27.07.15.

JUNIOR, D. W. B. Organização da informação no sistema de controle de manutenção da Universidade Estadual de Londrina. 2012. 65 f. Dissertação (Mestrado Profissional em Gestão da Informação) - Programa de PósGraduação em Gestão da Informação, Centro de Educação Comunicação e Artes, Universidade Estadual de Londrina. Londrina, 2012. Disponível em: < http://www.bibliotecadigital.uel.br/document/?code $=$ vtls0001811144 >. Acesso em: 27. 07. 15.

LAGE, S. R. M. A representação temática da informação na saúde coletiva: Tendências temáticas dos trabalhos desenvolvidos pelo programa de pósgraduação da Universidade Estadual de Londrina. 2014. 134 f. Dissertação (Mestrado em Ciência da Informação) - Programa de Pós-Graduação em Ciência da Informação, Centro de Educação, Comunicação e Artes, Universidade Estadual de Londrina. Londrina. 2014. Disponível em:<http://www.bibliotecadigital.uel.br/document/?code=vtls000193470>. Acesso: 27. 07. 15.

LENZI, L. A. F. Inovação tecnológica: Do funcionamento da palavra ao funcionamento do termo. 2006. 163 f. Dissertação (Mestrado em Ciência da Informação) - Programa de Pós-Graduação em Ciência da Informação, Pontifícia Universidade Católica de Campinas. Campinas, 2006. Disponível em: $<$ http://www.bibliotecadigital.puccampinas.edu.br/tde busca/arquivo. php?codArquivo=185>. Acesso em: 27.07.15.

MALTA, A. O. L. Memória em sais de prata: Fotografias do Recife em instituições memoriais. 2013. 206 f. Dissertação (Mestrado em Ciência da Informação) - Programa de Pós-Graduação em Ciência da Informação, centro de Artes e Comunicação, Universidade Federal de Pernambuco, Recife, 2013. Disponível em: $<$ http://repositorio.ufpe.br:8080/xmlui/handle/123456789/10248>. Acesso em: 27. 07. 15.

MARTINHO, Noemi Oliveira. A dimensão teórica e metodológica da catalogação de assunto. 2010. 189 f. Dissertação (Mestrado em Ciência da Informação) - Programa de Pós-Graduação em Ciência da Informação, Faculdade de Filosofia e Ciências, Universidade Estadual Paulista. Marília, 2010. Disponível em: < http://base.repositorio.unesp.br/handle/11449/9367> . Acesso em: 27.07.15. 
MATTOS, Terezinha de. Componentes espaciais, sociais e culturais em fotografias de Cuibá (MT) na década de 1920: subsídios para a leitura documental de imagens. 2008. 158 f. Dissertação (Mestrado em Ciência da Informação) - Programa de Pós-Graduação em Ciência da Informação, Faculdade de Filosofia e Ciências, Universidade Estadual Paulista. Marília, 2009. Disponível em: < http://base.repositorio.unesp.br/handle/11449/99357 >. Acesso em: 27.07.15.

MEDEIROS, J. W. Taxonomia navegacional facetada: análise à luz dos princípios da classificação facetada. 2013. 123 f. Dissertação (Mestrado em Ciência da Informação). Programa de Pós-Graduação em Ciência da Informação, Centro de Ciências da Educação, Universidade Federal de Santa Catarina. Florianópolis, 2013. Disponível em: < https://repositorio.ufsc.br/xmlui/handle/123456789/122840 >. Acesso em: 22. 07.15

NUNES, L. Da classificação das ciências à classificação da informação: Uma análise do acesso ao conhecimento. 2007. 121 f. Dissertação (Mestrado em Ciência da Informação) - Programa de Pós-Graduação em Ciência da Informação, Centro de Ciências Sociais Aplicada, Pontifícia Universidade Católica de Campinas. Campinas, 2007. Disponível em: < http://www.bibliotecadigital.puccampinas.edu.br/tde busca/arquivo.php?codArquivo=340>. Acesso em: 22. 07. 15.

OLIVEIRA, A. S. Horizonte compreensivo da biblioteca digital do pesquisador. 2013. 113 f. Dissertação (Mestrado em Ciência da Informação) Programa de Pós-Graduação em Ciência da Informação, Instituto de Ciência da Informação, Universidade Federal da Bahia. Salvador, 2013. Disponível em: $<$ http://www.repositorio.ufba.br/ri/handle/ri/7942>. Acesso em: 27. 07. 15.

ORTH, Gabriela Previdello Ferreira. Tratamento da informação nas artes digitais: uma abordagem contemporânea da documentação em meios tecnológicos. 2013. 152 f. Dissertação (Mestrado em Cultura e Informação) Programa de Pós-Graduação em Ciência da Informação, Escola de Comunicações e Artes, Universidade de São Paulo. São Paulo, 2013. Disponível em: < http://www.teses.usp.br/teses/disponiveis/27/27151/tde04122013-230044/ >. Acesso em: 22. 07.15

PADILHA, R. C. O museu como espaço de pesquisa: Proposta para descrição do acervo fotográfico histórico. 2014. 135 f. Dissertação (Mestrado em Ciência da Informação) - Programa de Pós-Graduação em Ciência da Informação, Centro de Ciências da Educação, Universidade Federal de Santa Catarina. Florianópolis, 2014. Disponível em: < https://repositorio.ufsc.br/xmlui/handle/123456789/123241>. Acesso em: 22. 07.15. 
PAULUCCI, M. R. B. C. O fluxo informacional para as ações de resposta a desastres naturais em áreas urbanas com base na logística humanitária. 2013. 163 f. Dissertação (Mestrado em Ciência Tecnologia e Sociedade) Programa de Pós-Graduação em Ciência Tecnologia e Sociedade, Centro de Educação e Ciências Humanas, Universidade Federal de São Carlos. São Carlos, 2013. Disponível em: < http://www.bdtd.ufscar.br/htdocs/tedeSimplificado//tde busca/arquivo.php?codA rquivo $=5947>$. Acesso em: 22.07.15

PREVIDI, J. Termos técnicos das ações e procedimentos no âmbito do Instituto Paranaense de Desenvolvimento Econômico e Social - IPARDES. 2011. 114 f. Dissertação (Mestrado em Gestão da Informação) - Programa de Pós-Graduação em Gestão da Informação, Centro de Educação Comunicação e Artes, Universidade Estadual de Londrina. Londrina, 2011. Disponível em: < http://www.bibliotecadigital.uel.br/document/?code=vtls000169016>. Acesso em: 27. 07. 15.

QUEIROZ, Malthus Oliveira de. Gestão da Informação para organização do conhecimento no terceiro setor: Um estudo de caso na AERPA. 2013. 288 f. Dissertação (Mestrado em Ciência da Informação) - Programa de PósGraduação em Ciência da Informação, centro de Artes e Comunicação, Universidade Federal de Pernambuco. Recife, 2013. Disponível em: <http://repositorio.ufpe.br:8080/xmlui/handle/123456789/10443 >. Acesso em: 27. 07. 15.

RIZZI, luri Rocio Franco. A paz nos instrumentos de organização da informação: uma análise dos conceitos de paz e guerra, da cultura de paz e dos estudos para a paz na Classificação Decimal Dewey. 2008. 102 f. Dissertação (Mestrado em Ciência da Informação) - Programa de PósGraduação em Ciência da Informação, Faculdade de Filosofia e Ciências, Universidade Estadual Paulista. Marília, 2009. Disponível em: < http://base.repositorio.unesp.br/handle/11449/95530 >. Acesso em: 27.07.15.

ROCHA, Evandro Farias. Busca e uso da informação como suporte ao processo decisório: Estudo de caso em uma instituição pública de ensino superior. 2014. 105 f. Dissertação (Mestrado Profissional: Gestão nas Organizações Aprendentes) - Programa de Pós-Graduação em Gestão nas Organizações Aprendentes, Centro de Ciências Sociais Aplicadas/Centro de Educação, Universidade Federal da Paraíba. João Pessoa, 2014. Disponível em: < http://tede.biblioteca.ufpb.br:8080/handle/tede/5929>. Acesso em: 22. 07. 15.

SANTANA, Vanessa Alves. Memória esquecida: uma análise da organização e representação da informação étnico-racial no OPAC da Biblioteca Central da Universidade Federal da Paraíba. 2012. 139 f. Dissertação (Mestrado em Ciência da Informação) - Centro de Ciências Sociais Aplicadas, Universidade Federal da Paraíba. João Pessoa, 2012. Disponível em: < http://tede.biblioteca.ufpb.br:8080/handle/tede/3931 >. Acesso em: 22.07.15 
SANTOS, Derlei Alberto dos. Projeto Memória Votorantim: construindo a memória corporativa e o uso das narrativas locais. 2012. 128 f. Dissertação (Mestrado em Ciência da Informação) - Programa de Pós-Graduação em Ciência da Informação, Faculdade de Filosofia e Ciências, Universidade Estadual Paulista. Marília, 2012. Disponível em: < http://hdl.handle.net/11449/93685>. Acesso em: 27.07.15

SANTOS, Monick Trajano dos. Estudo do processo de apropriação da ontologia pela Ciência da Informação no Brasil. 2014. 271 f. Dissertação (Mestrado em Ciência da Informação) - Programa de Pós-Graduação em Ciência da Informação, centro de Artes e Comunicação, Universidade Federal de Pernambuco. Recife, 2014. Disponível em:

$<$ http://repositorio.ufpe.br:8080/xmlui/handle/123456789/12945 >. Acesso em: 27 jul. 15.

SEMENSATTO, S. Classificação do conhecimento nas esferas de produção e comunicação do saber: A exposição "Em casa, no universo" do Museu da Universidade Federal do Rio Grande do Sul. Dissertação (Mestrado em Comunicação e Informação) - Programa de Pós-Graduação em Comunicação e Informação, Faculdade de Biblioteconomia e Comunicação, Universidade Federal do Rio Grande do Sul. Porto Alegre, 2010. Disponível em: < http://hdl.handle.net/10183/24510>. Acesso em: 27. 07. 15.

SOARES, N. C. A organização da informação no âmbito das instituições de ensino superior: Em foco os relatórios finais da assessoria de estatística do Centro de Ciências Exatas da Universidade Estadual de Londrina. 2012. 83 f. Dissertação (Mestrado Profissional em Gestão da Informação) - Programa de Pós-Graduação em Gestão da Informação, Centro de Educação Comunicação e Artes, Universidade Estadual de Londrina. Londrina, 2012. Disponível em: < http://www.bibliotecadigital.uel.br/document/?code=vtls000180284 >. Acesso em: 27. 07. 15.

SOUZA JUNIOR, M. B. d. Análise de tipos de ontologias nas áreas de ciência da informação e ciência da computação. 2014. 142 f. Dissertação (Mestrado em Ciência da Informação) - Programa de Pós-Graduação em Ciência da Informação, Centro de Ciências da Educação, Universidade Federal de Santa Catarina. Florianópolis, 2014. Disponível em:< https://repositorio.ufsc.br/xmlui/handle/123456789/1234181>. Acesso em: 22. 07.15.

TARTAROTTI, R. C. D. E. Atuação bibliotecária no tratamento temático da informação em unidades informacionais: Um estudo comparativo qualitativoquantitativo. 2013. ?? f. Dissertação (Mestrado em Ciência Tecnologia e Sociedade) . Programa de Pós-Graduação em Ciência Tecnologia e Sociedade, Centro de Educação e Ciências Humanas, Universidade Federal de São Carlos. São Carlos, 2013. Disponível em: < http://www.bdtd.ufscar.br/htdocs/tedeSimplificado//tde busca/arquivo.php?codA rquivo $=7884>$ Acesso em: 22. 07. 15. (Arquivo com conteúdo liberado 
somente para a comunidade da Universidade ou Retido por motivo de patente requerido pelo autor).

TORINO, L. P. Organização da produção científica em repositórios institucionais: Um parâmetro para a UTFPR. 2010. 150 f. Dissertação (Mestrado Profissional em Gestão da Informação) - Programa de PósGraduação em Gestão da Informação, Centro de Educação Comunicação e Artes, Universidade Estadual de Londrina. Londrina. 2010. Disponível em: < http://www.bibliotecadigital.uel.br/document/?code=vtls000161238 >. Acesso em: 22. 07. 15.

VELAME, Robélia. Repositórios Institucionais: Organização e tratamento informacional dos recursos digitais. 2011. 240 f. Dissertação (Mestrado em Ciência da Informação) - Programa de Pós-Graduação em Ciência da Informação, Instituto de Ciência da Informação, Universidade Federal da Bahia. Salvador, 2013. Disponível em: < http://www.repositorio.ufba.br/ri/handle/ri/7839 >. Acesso em: 27. Jul. 15.

VIEIRA, J. M. d. L. A contribuição da Organização e da Visualização da Informação para os Sistemas de Recuperação de Informação. 2014. 227 f. Dissertação (Mestrado em Ciência da Informação) - Programa de PósGraduação em Ciência da Informação, Centro de Artes e Comunicação, Universidade Federal de Pernambuco. Recife, 2014. Disponível em: < http://repositorio.ufpe.br:8080/xmlui/handle/123456789/129444 >. Acesso em: 27. 07. 15.

VOLPATO, Enilze de Souza Nogueira. Subsídios para construção de estratégias de busca para revisões sistemáticas na base de dados Medline via Pubmed. 2013. 176 f. Dissertação (Mestrado em Bases Gerais de Cirurgia) - Faculdade de Medicina de Botucatu, Universidade Estadual Paulista. 2013, Botucatu. Disponível em: < http://base.repositorio.unesp.br/handle/11449/90371 >. Acesso em: 27.07.15.

ZANIN, F. E. G. A organização da informação policial no âmbito da segurança pública do estado do Paraná: Em foco o boletim de ocorrência unificado. 2011. 118 f. Dissertação (Mestrado Profissional em Gestão da Informação). Programa de Pós-Graduação em Ciência da Informação, Centro de Educação Comunicação e Artes, Universidade Estadual de Londrina. Londrina, 2011. Disponível em: < http://www.bibliotecadigital.uel.br/document/?code=vtls000167739 >. Acesso em: 22. 07. 15.

\section{ENANCIBs}


ALMEIDA, Adriana Olinto Ballesté Alea de. Organização e representação da informação no museu virtual de instrumentos musicais. In: ENANCIB, XV. 2014, Belo Horizonte. Além das nuvens: Expandindo as fronteiras da ciência da informação. Belo Horizonte: ECl, 2014. P. 848 - 868. Disponível em: < http://enancib2014.eci.ufmg.br/documentos/anais/anais-gt2 >. Acesso em: 27.07.15. (ISSN 2177-3688)

ALMEIDA, Carlos Cândido de; GUIMARÃES, José Augusto Chaves. Análise Peirceana do Processo de Indexação: em busca de fundamentos para a organização da informação. In: ENANCIB, IX. 2008, São Paulo. Diversidade cultural e políticas de informação. São Paulo: USP, 2008. Disponível em:< http://enancib.ibict.br/index.php/enancib/ixenancib/paper/view/3000/2126>.

Acesso em: 27.07.15.

ALMEIDA, Carlos Cândido de; GUIMARÃES, José Augusto Chaves. Peirce e a ciência da informação: considerações preliminares sobre as relações entre a obra peirceana e a organização da informação. In: ENANCIB, VIII. 2007, Salvador. Promovendo a inserção internacional da pesquisa brasileira em Ciência da Informação. Salvador: PPGCI/UFBA, 2007. Disponível em: < http://enancib.ibict.br/index.php/enancib/viiienancib/paper/view/2832/1960>. Acesso em: 27.07.15.

AMORIM, Igor Soares; CAFÉ, Lígia Maria Arruda. Análise de domínio hjørlandiana sob a luz da filosofia de deleuze. In: ENANCIB, XV. 2014, Belo Horizonte. Além das nuvens: Expandindo as fronteiras da ciência da informação. Belo Horizonte: ECl, 2014. P. 1044 - 1050. Disponível em: < http://enancib2014.eci.ufmg.br/documentos/anais/anais-gt2 >. Acesso em: 27.07.15. (ISSN 2177-3688)

ANDRADE, Julietti de; LARA, Marilda Lopes Ginez de. A linguística documentária e a análise de domínio na organização da informação. In:

ENANCIB, XII. 2011, Brasília. Políticas de informação para a sociedade. Brasília: FCI/UNB, 2011. Disponível em: < http://enancib.ibict.br/index.php/enancib/enancibXII/paper/view/956 >. Acesso em: 27.07.15.

ANDRADE, Morgana Carneiro de; CERVANTES, Brígida Maria Nogueira. Interoperabilidade semântica entre repositórios institucionais brasileiros: 0 papel da organização do conhecimento. In: ENANCIB, XIII. 2012, Rio de Janeiro. A sociedade em rede para a inovação e o desenvolvimento humano. Rio de Janeiro: FIOCRUZ, 2012. Disponível em: < http://www.eventosecongressos.com.br/metodo/enancib2012/arearestrita/pdfs/1 9365.pdf >. Acesso em: 27.07.15.

ARBOIT, Aline Elis; GUIMARÃES, José Augusto Chaves. Conhecimento e linguagem na organização do conhecimento: aspectos dialógicos a partir da concepção de Bakhtin. In: ENANCIB, XIV. 2013, Belo Horizonte. Informação e 
interação: Ampliando perspectivas para o desenvolvimento humano. Belo Horizonte: ECl, 2013. Disponível em: < http://enancib.sites.ufsc.br/index.php/enancib2013/XIVenancib/paper/view/158/ $\underline{413}$ >. Acesso em: 27.07.15.

ARTÊNCIO, Luciane Maria. Sobre as inflências sócio-culturais da categorização nas linguagens documentárias. In: ENANCIB, VIII. 2007, Salvador. Promovendo a inserção internacional da pesquisa brasileira em Ciência da Informação. Salvador: PPGCI/UFBA, 2007. Disponível em: < http://enancib.ibict.br/index.php/enancib/viiienancib/paper/view/2841/1969 >. Acesso em: 27.07.15.

AVANZO, Luciana; MOREIRA, Walter. O vocabulário controlado como ferramenta do processo de organização e recuperação da informação. In: ENANCIB, XV. 2014, Belo Horizonte. Além das nuvens: Expandindo as fronteiras da ciência da informação. Belo Horizonte: $\mathrm{ECl}$, 2014. P. 11361142. Disponível em: < http://enancib2014.eci.ufmg.br/documentos/anais/anaisgt2 >. Acesso em: 27.07.15. (ISSN 2177-3688)

BIOLCHINI1, Jorge Calmon de Almeida. Semântica na representação do conhecimento: do vocabulário controlado à ontologia. In: ENANCIB,V.2003, Belo Horizonte. Informação, Conhecimento e Transdisciplinaridade: desafios do milênio. Belo Horizonte: ECI/UFMG, 2003. Disponível em: < http://enancib.ibict.br/index.php/enancib/venancib/paper/view/1911/1052>. Acesso em: 27.07.15.

BORBA, Vildeane da Rocha. et al. Desenvolvimento de cursos a distância na área de saúde pela UFPE: uma perspectiva em mapas conceituais. In: ENANCIB, XIV. 2013, Belo Horizonte. Informação e interação: Ampliando perspectivas para o desenvolvimento humano. Belo Horizonte: ECl, 2013. Disponível em: < http://enancib.sites.ufsc.br/index.php/enancib2013/XIVenancib/paper/view/447/ $\underline{428}$ >. Acesso em: 27.07.15.

BRASCHER, Marisa; CAFÉ , Lígia. Organização da Informação ou Organização do Conhecimento?. In: ENANCIB, IX. 2008, São Paulo. Diversidade cultural e políticas de informação. São Paulo: USP, 2008. Disponível em:< http://enancib.ibict.br/index.php/enancib/ixenancib/paper/view/3016/2142 >. Acesso em: 27.07.15.

BRÄSCHER, Marisa; OLIVEIRA, Ana Karla Souza de. Organização de conteúdos do serviço brasileiro de repostas técnicas - SBRT. In: ENANCIB,VI. 2005, Florianópolis. A política científica e os desafios da sociedade da informação. Florianópolis: CIN/UFSC, 2005. Disponível em: < http://enancib.ibict.br/index.php/enancib/vienancib/paper/view/1745/879 $>$. Acesso em: 27.07.15. 
CERVANTES, Brigida Maria Nogueira; LIMA FILHO, Antonio Bezerra de. A organização da informação em sites de recursos humanos. In: ENANCIB, XII. 2011, Brasília. Políticas de informação para a sociedade. Brasília: FCI/UNB, 2011. Disponível em: < http://enancib.ibict.br/index.php/enancib/enancibXII/paper/view/977>. Acesso em: 27.07.15.

DIAS, Geneviane Duarte; CERVANTES, Brígida Maria Nogueira. A organização temática da informação em periódicos científicos eletrônicos: atribuição de palavras-chave na biblioteconomia e ciência da informação. In: ENANCIB, XIV. 2013, Belo Horizonte. Informação e interação: Ampliando perspectivas para o desenvolvimento humano. Belo Horizonte: ECI, 2013. Disponível em: < http://enancib.sites.ufsc.br/index.php/enancib2013/XIVenancib/paper/view/481/ 131>. Acesso em: 27.07.15.

DODEBEI, Vera. Memória e conhecimento: oralidade, visualidade e reprodutibilidade no fluxo da informação. In: ENANCIB, X. 2009, João Pessoa. A Responsabilidade social da ciência da informação. João Pessoa: UFPB, 2009. Disponível em:<

http://enancib.ibict.br/index.php/enancib/xenancib/paper/view/3167/2293>. Acesso em: 27.07.15.

DODEBEI,Vera. Digitalização do patrimônio e organização do conhecimento. In: ENANCIB, VIII. 2007, Salvador. Promovendo a inserção internacional da pesquisa brasileira em Ciência da Informação. Salvador: PPGCI/UFBA, 2007. Disponível em: < http://enancib.ibict.br/index.php/enancib/viiienancib/paper/view/2815/1943>. Acesso em: 27.07.15.

EUCLIDES, Maria Luzinete; FUJITA, Mariângela Spotti Lopes. Representação das necessidades de informação na organização da informação. In: ENANCIB, VIII. 2007, Salvador. Promovendo a inserção internacional da pesquisa brasileira em Ciência da Informação. Salvador: PPGCI/UFBA, 2007. Disponível em: < http://enancib.ibict.br/index.php/enancib/viiienancib/paper/view/2838/1966 >. Acesso em: 27.07.15.

EVANGELISTA, Isadora Victorino; GUIMARÃES, José Augusto Chaves; ALMEIDA, Carlos Cândido. A semiótica como subsídio para a representação do conhecimento: uma análise conceitual sobre o tema. In ENANCIB, XV. 2014, Belo Horizonte. Além das nuvens: Expandindo as fronteiras da ciência da informação. Belo Horizonte: ECl, 2014. P. 395 - 429. Disponível em: < http://enancib2014.eci.ufmg.br/documentos/anais/anais-gt2>. Acesso em: 27.07.15. (ISSN 2177-3688) 
FARIAS, Mona Cleide Quirino da Silva. ALMEIDA, Carlos Cândido de. Semiótica da cultura e abordagens socioculturais: possíveis diálogos. In: ENANCIB, XV. 2014, Belo Horizonte. Além das nuvens: Expandindo as fronteiras da ciência da informação. Belo Horizonte: ECI, 2014. P. 869 893. Disponível em: < http://enancib2014.eci.ufmg.br/documentos/anais/anaisgt2 >. Acesso em: 27.07.15. (ISSN 2177-3688)

FERNANDES, Joliza Chagas; KOBASHI, Nair Yumiko. Relações de significação em ontologias. In: ENANCIB, XIII. 2012, Rio de Janeiro. A sociedade em rede para a inovação e o desenvolvimento humano. Rio de Janeiro: FIOCRUZ, 2012. Disponível em: < http://enancib.ibict.br/index.php/enancib/xiiienancib/paper/viewFile/3699/2822

GALVÃO, Maria Cristiane Barbosa. Linguagens empregadas em prontuários do paciente frente aos processos de organização e recuperação da informação no contexto da saúde. In: ENANCIB, IX. 2008, São Paulo. Diversidade cultural e políticas de informação. São Paulo: USP, 2008. Disponível em: < http://enancib.ibict.br/index.php/enancib/ixenancib/paper/view/3013/2139 >. Acesso em: 27.07.15.

GALVÃO, Maria Cristiane Barbosa. Modelo para representação da informação em manuais técnicos. In: ENANCIB,VI. 2005, Florianópolis. A política científica e os desafios da sociedade da informação. Florianópolis: CIN/UFSC, 2005. Disponível em: < http://enancib.ibict.br/index.php/enancib/vienancib/paper/view/1740/874 >. Acesso em: 27.07.15.

GALVÃO, Maria Cristiane Barbosa; MARQUES, Paulo Mazzoncini de Azevedo; FELIPE, Joaquim Cezar. Da gênese à representação da informação:

mapeando superestruturas textuais no setor da saúde. In: ENANCIB, VII. 2006, Marília. A dimensão epistemológica da Ciência da Informação e suas interfaces técnicas, políticas e institucionais nos processos de produção, acesso e disseminação da informação. Marília : FFC/UNESP, 2006.

Disponível em:

<http://enancib.ibict.br/index.php/enancib/viienancib/paper/view/2429/1560>.

Acesso em: 27.07.15.

GUEDES, Emanuel G. F.; MORAES, João Batista E. de Moraes. O processo de identificação de assuntos para a representação da informação: uma análise do conceito Aboutness. In: ENANCIB, IX. 2008, São Paulo. Diversidade cultural e políticas de informação. São Paulo: USP, 2008. Disponível em:< http://enancib.ibict.br/index.php/enancib/ixenancib/paper/view/3005/2131 >. Acesso em: 27.07.15.

KOBASHI, Nair Yumiko; FERNANDES, Joliza Chagas. Pragmática linguística e organização da informação.In: ENANCIB, X. 2009, João Pessoa. A

Responsabilidade social da ciência da informação. João Pessoa: UFPB, 2009. Disponível em:< 
http://enancib.ibict.br/index.php/enancib/xenancib/paper/view/3172/2298 >. Acesso em: 27.07.15.

LARA, Marilda Lopes Ginez de. Uma teoria terminológica para um conceito contemporâneo de informação documentária. In: ENANCIB,VI. 2005, Florianópolis. A política científica e os desafios da sociedade da informação. Florianópolis: CIN/UFSC, 2005. Disponível em: < http://enancib.ibict.br/index.php/enancib/vienancib/paper/view/1753/887>. Acesso em: 27.07.15.

LIMA , João Alberto de Oliveira; CUNHA, Murilo Bastos da. Modelo genérico de relacionamentos e a organização da informação. In: ENANCIB, X. 2009, João Pessoa. A Responsabilidade social da ciência da informação. João Pessoa: UFPB, 2009. Disponível em:< http://enancib.ibict.br/index.php/enancib/xenancib/paper/view/3168/2294 >. Acesso em: 27.07.15.

LIMA, Gercina Ângela Borém de Oliveira. Gerenciamento do conteúdo semântico no protótipo mapa hipertextual-mhtx: perspectivas. In: ENANCIB, VIII. 2007, Salvador. Promovendo a inserção internacional da pesquisa brasileira em Ciência da Informação. Salvador: PPGCI/UFBA, 2007. Disponível em: < http://enancib.ibict.br/index.php/enancib/viiienancib/paper/view/2817/1945>. Acesso em: 27.07.15.

LIMA, Gercina Ângela Borém Oliveira. A análise facetada na modelagem conceitual para organização hipertextual de documentos acadêmicos: sua aplicação no prototipo MHTX (mapa hipertextual). In: ENANCIB,VII. 2006, Marília. A dimensão epistemológica da Ciência da Informação e suas interfaces técnicas, políticas e institucionais nos processos de produção, acesso e disseminação da informação. Marília: FFC/UNESP, 2006.

Disponível em: < http://enancib.ibict.br/index.php/enancib/viienancib/paper/view/2417/1548>. Acesso em: 27.07.15.

MARQUES, Katia; ODDONE, Nanci. Organização da informação na plataforma lattes.In: ENANCIB, XII. 2010, Rio de Janeiro. Inovação e inclusão social: questões contemporâneas da informação. Rio de Janeiro: IBICT, 2010. Disponível em: < http://congresso.ibict.br/index.php/enancib/xienancib/paper/viewFile/3423/2549 >. Acesso em: 27.07.15.

MARQUES, Katia; ODDONE, Nanci; MIRANDA, Marcos. Organização da informação na plataforma lattes: o módulo produção bibliográfica. In: ENANCIB, VIII. 2007, Salvador. Promovendo a inserção internacional da pesquisa brasileira em Ciência da Informação. Salvador: PPGCI/UFBA, 2007. Disponível em: < 
http://enancib.ibict.br/index.php/enancib/viiienancib/paper/view/2829/1957>. Acesso em: 27.07.15.

MEDEIROS, Jackson da Silva Medeiros;CAMPOS, Maria Luiza de Almeida. Tesauros conceituais e ontologias de fundamentação: análise comparativa entre as bases teórico-metodológicas utilizadas em seus modelos de representação de domínios. In: ENANCIB, XII. 2011, Brasília. Políticas de informação para a sociedade. Brasília: FCI/UNB, 2011. Disponível em: < http://enancib.ibict.br/index.php/enancib/enancibXII/paper/view/1109>. Acesso em: 27.07.15.

MIRANDA, Marcos Luiz Cavalcanti de; et al. A organização e representação do conhecimento e a recuperação da informação em neurologia nos websites especializados. In: ENANCIB, XII. 2010, Rio de Janeiro. Inovação e inclusão social: questões contemporâneas da informação. Rio de Janeiro: IBICT, 2010. Disponível em:<http://enancib.ibict.br/index.php/enancib/xienancib/paper/view/3426/2552>. Acesso em: 27.07.15.

MIRANDA, Marcos Luiz. Organização e representação do conhecimento: fundamentos teórico-metodológicos na busca e recuperação da informação em ambientes virtuais. In: ENANCIB, VII. 2006, Marília. A dimensão epistemológica da Ciência da Informação e suas interfaces técnicas, políticas e institucionais nos processos de produção, acesso e disseminação da informação. Marília: FFC/UNESP, 2006. Disponível em: $<$ http://enancib.ibict.br/index.php/enancib/viienancib/paper/viewFile/2433/1564> Acesso em: 27.07.15.

MOREIRA, Manoel Palhares; MOURA, Maria Aparecida. Ambiente para manutenção semi-automatizada de tesauros. In: ENANCIB, VII.2006, Marília. A dimensão epistemológica da Ciência da Informação e suas interfaces técnicas, políticas e institucionais nos processos de produção, acesso e disseminação da informação. Marília : FFC/UNESP, 2006. Disponível em: $<$ http://enancib.ibict.br/index.php/enancib/viienancib/paper/view/2420/1551>. Acesso em: 27.07.15.

MOREIRA, Manoel Palhares; MOURA, Maria Aparecida. Estratégias de produção e organização de informações na www: conceitos para um método de análise de sites. In: ENANCIB,VII. 2006, Marília. A dimensão epistemológica da Ciência da Informação e suas interfaces técnicas, políticas e institucionais nos processos de produção, acesso e disseminação da informação. Marília : FFC/UNESP, 2006. Disponível em:

$<$ http://enancib.ibict.br/index.php/enancib/viienancib/paper/view/2420/1551>.Ac esso em: 27.07.15.

MOREIRA, Manoel Palhares; PFEILSTICKER, Igor Seufferheld de Oliveira; STEMPLIUC, Sergio Murilo. Formação de um vocabulário controlado a partir de palavras-chave. In: ENANCIB,VI. 2005, Florianópolis. A política científica e os 
desafios da sociedade da informação. Florianopolis: CIN/UFSC, 2005. Disponível em: < http://enancib.ibict.br/index.php/enancib/venancib/paper/view/1911/1052 >. Acesso em: 27.07.15.

MOREIRA, Manoel Palhares; STEMPLIUC, Sergio Murilo. Reconhecimento de títulos de artigos não condizentes com seu conteúdo através da utilização de palavras-chave. In: ENANCIB, VII.2006, Marília. A dimensão epistemológica da Ciência da Informação e suas interfaces técnicas, políticas e institucionais nos processos de produção, acesso e disseminação da informação. Marília : FFC/UNESP, 2006. Disponível em:

$<$ http://enancib.ibict.br/index.php/enancib/viienancib/paper/view/2418/1549>. Acesso em: 27.07.15.

MORENO, Fernanda Passini. Em busca dos objetivos bibliográficos. In: ENANCIB, XIII. 2012, Rio de Janeiro. A sociedade em rede para a inovação e o desenvolvimento humano. Rio de Janeiro: FIOCRUZ, 2012. Disponível em: $<$ http://www.eventosecongressos.com.br/metodo/enancib2012/arearestrita/pdfs/1 9446.pdf >. Acesso em: 27.07.15.

MOURA, Maria Aparecida. Representação informacional e as temáticas nacionais: desafios e tendências para a elaboração de linguagens de indexação. In: ENANCIB,VI. 2005, Florianópolis. A política científica e os desafios da sociedade da informação. Florianópolis: CIN/UFSC, 2005. Disponível em: < http://enancib.ibict.br/index.php/enancib/vienancib/paper/view/1749/883 >. Acesso em: 27.07.15.

NOVO, Hildenise Ferreira; CAMPOS, Maria Luiza de Almeida. Taxonomias de domínios interdisciplinares: uma experiência com a área de geoquímica ambiental. In: ENANCIB, VIII. 2007, Salvador. Promovendo a inserção internacional da pesquisa brasileira em Ciência da Informação. Salvador: PPGCI/UFBA, 2007. Disponível em: < http://enancib.ibict.br/index.php/enancib/viiienancib/paper/view/2844/1972>.

Acesso em: 27.07.15.

ORTEGA. Cristina Dota. A Ordenação de documentos como atividade de organização da informação: Proposta de fundamentação e atualização. In: ENANCIB, XIV. 2013, Belo Horizonte. Informação e interação: Ampliando perspectivas para o desenvolvimento humano. Belo Horizonte: ECl, 2013. Disponível em: < http://enancib.sites.ufsc.br/index.php/enancib2013/XIVenancib/paper/viewFile/1 19/133 >. Acesso em: 27.07.15.

ORTH, Gabriela Previdello; LARA, Marilda Lopes Ginez de. Redes e agentes da arte digital: iniciativas para o tratamento da informação. In: ENANCIB, XIV. 2013, Belo Horizonte. Informação e interação: Ampliando perspectivas para 
o desenvolvimento humano. Belo Horizonte: ECI, 2013. Disponível em: < http://enancib.sites.ufsc.br/index.php/enancib2013/XIVenancib/paper/view/481/ 131>. Acesso em: 27.07.15.

PATO, Paulo Roberto Gomes. Ícone, índice e símbolo, fundamentos para ler e organizar a informação em imagens. In: ENANCIB, XV. 2014, Belo Horizonte. Além das nuvens: Expandindo as fronteiras da ciência da informação. Belo Horizonte: ECI, 2014. P. 488 - 508. Disponível em: < http://enancib2014.eci.ufmg.br/documentos/anais/anais-gt2>. Acesso em: 27.07.15. (ISSN 2177-3688)

PINHO, Fábio Assis; MARINHO, Andrea Carla Melo; NASCIMENTO, Francisco Arrais. A organização do conhecimento nas letras das músicas de luiz gonzaga: uma análise temática do ciclo junino. In: ENANCIB, XIV. 2013, Belo Horizonte. Informação e interação: Ampliando perspectivas para 0 desenvolvimento humano. Belo Horizonte: ECI, 2013. Disponível em: < http://enancib.sites.ufsc.br/index.php/enancib2013/XIVenancib/paper/view/488/ $\underline{432}$ >. Acesso em: 27.07.15.

RAMALHO, Rogério Aparecido Sá. Representação do conhecimento e ontologias: reflexões interdisciplinares. In: ENANCIB, X. 2009, João Pessoa. A Responsabilidade social da ciência da informação. João Pessoa: UFPB, 2009. Disponível em:< http://enancib.ibict.br/index.php/enancib/xenancib/paper/view/3175/2301 >. Acesso em: 27.07.15.

RODRIGUES, Kátia; ODDONE, Nanci. Aferindo os descritores temáticos do portal da capes para a coleção de periódicos da ciência da informação. In: ENANCIB, VIII. 2007, Salvador. Promovendo a inserção internacional da pesquisa brasileira em Ciência da Informação. Salvador:

PPGCI/UFBA,2007. Disponível

em:<http://enancib.ibict.br/index.php/enancib/viiienancib/paper/view/2809/1937 >. Acesso em: 27.07.15.

SALES, Luana Farias. Relações conceituais para instrumentos de padronização terminológica: um novo modelo para o uso em ontologias. In: ENANCIB, VIII. 2007, Salvador. Promovendo a inserção internacional da pesquisa brasileira em Ciência da Informação. Salvador: PPGCI/UFBA, 2007. Disponível em:

<http://repositorios.questoesemrede.uff.br/repositorios/handle/123456789/157>. Acesso em: 27.07.15.

SANTO, Silvia Maria Espírito.Alguns elementos do problema entre colecionismo e contexto cultural. In: ENANCIB, XII. 2010, Rio de Janeiro. Inovação e inclusão social: questões contemporâneas da informação. Rio de Janeiro: IBICT, 2010. Disponível em:

$<$ http://enancib.ibict.br/index.php/enancib/enancibXII/paper/view/977>. Acesso em: 27.07.15. 
SILVA, Alessandra Rodrigues d., BAPTISTA, Dulce MARIA. As manifestações do tempo na organização da informação e na organização do conhecimento. In: ENANCIB, XIV. 2013, Belo Horizonte. Informação e interação: Ampliando perspectivas para o desenvolvimento humano. Belo Horizonte: ECI, 2013. Disponível em: $<$ http://enancib.sites.ufsc.br/index.php/enancib2013/XIVenancib/paper/view/331 $\underline{1425}$ >. Acesso em: 27.07.15.

SILVEIRA, Letícia Reis da.; GRACIOSO Luciana de Souza. Metodologias, instrumentos e interfaces de organização da imagem na web no contexto do sistema "memória virtual". In: ENANCIB, XV. 2014, Belo Horizonte. Além das nuvens: Expandindo as fronteiras da ciência da informação. Belo Horizonte: ECI, 2014. P. 1051-1057. Disponível em:

<http://enancib2014.eci.ufmg.br/documentos/anais/anais-gt2>. Acesso em: 27.07.15. (ISSN 2177-3688)

SíNDICO, Sergio Ricardo Ferreira; SOUZA, Rosali Fernandez de. A Medicina e sua representação em linguagens documentárias: marcos na evolução dos ambientes e ferramentas de tratamento da informação. In: ENANCIB, IX. 2008, São Paulo. Diversidade cultural e políticas de informação. São Paulo: USP, 2008. Disponível

em:<http://enancib.ibict.br/index.php/enancib/ixenancib/paper/view/3021/2147>. Acesso em: 27.07.15.

SOUZA, Joice Cleide Cardoso Ennes de; ALMEIDA, Elan Cardozo Paes de. Abordagem teórico-metodológica na organização de imagens em patologia. In: ENANCIB, XV. 2014, Belo Horizonte. Além das nuvens: Expandindo as fronteiras da ciência da informação. Belo Horizonte: $\mathrm{ECI}, 2014$. P. 778 788. Disponível em: < http://enancib2014.eci.ufmg.br/documentos/anais/anaisgt2 >. Acesso em: 27.07.15. (ISSN 2177-3688)

SOUZA, Rosali Fernandez de. Organização e representação de áreas do conhecimento em ciência e tecnologia: princípios de agregação em grandes áreas segundo diferentes contextos de produção e uso de informação. In: ENANCIB,VI. 2005, Florianópolis. A política científica e os desafios da sociedade da informação. Florianópolis: CIN/UFSC, 2005. Disponível em: <http://enancib.ibict.br/index.php/enancib/vienancib/paper/view/1746/880>. Acesso em: 27.07.15.

TORINO, Lígia Patrícia; CERVANTES, Brígida Maria Nogueira. Organização da informação em repositórios institucionais: um parâmetro para a descrição da produção científica. In: ENANCIB, XII. 2010, Rio de Janeiro. Inovação e inclusão social: questões contemporâneas da informação. Rio de Janeiro: IBICT, 2010. Disponível em:<http://enancib.ibict.br/index.php/enancib/xienancib/paper/view/3429/2555>. Acesso em: 27.07.15. 
VIEIRA, Jéssica Monique de Lira; PINHO, Fábio Assis. Estudo da relação entre organização e visualização da informação a partir de sistemas de recuperação da informação. In ENANCIB, XV. 2014, Belo Horizonte. Além das nuvens: Expandindo as fronteiras da ciência da informação. Belo Horizonte: $\mathrm{ECl}$, 2014. P. 334 - 354. Disponível em: < http://enancib2014.eci.ufmg.br/documentos/anais/anais-gt2334 >. Acesso em: 27.07.15. (ISSN 2177-3688)

VITAL, Luciane Paula; CAFÉ, Ligia Maria Arruda. Práticas de elaboração de taxonomias: análise e recomendações. In: ENANCIB, VIII. 2007, Salvador.

Promovendo a inserção internacional da pesquisa brasileira em Ciência da Informação. Salvador: PPGCI/UFBA, 2007. Disponível em: < http://enancib.ibict.br/index.php/enancib/viiienancib/paper/view/2833/1961>. Acesso em: 27.07.15.

WATANABE, Eduardo. A arquitetura de metadados de processos judiciais cíveis. In: ENANCIB, XV. 2014, Belo Horizonte. Além das nuvens:

Expandindo as fronteiras da ciência da informação. Belo Horizonte: $\mathrm{ECl}$, 2014. P. 1122-1228. Disponível em: < http://enancib2014.eci.ufmg.br/documentos/anais/anais-gt2 >. Acesso em: 27. 07.15. (ISSN 2177-3688)

WEISS, Leila Cristina; BRÄSCHER, Marisa. Pragmática na organização do Conhecimento. In: ENANCIB, XV. 2014, Belo Horizonte. Além das nuvens: Expandindo as fronteiras da ciência da informação. Belo Horizonte: $\mathrm{ECl}$, 2014. P. 681 - 701. Disponível em: < http://enancib2014.eci.ufmg.br/documentos/anais/anais-gt2 >. Acesso em: 27. 07. 15. (ISSN 2177-3688) 
Apêndice B - Tabela 4 - Termos que ocorrem juntos com a produção científica descrita com os termos Ol (organização da informação); OC (organização do conhecimento); OI/OC (organização da informação/organização do conhecimento)

\begin{tabular}{|c|c|c|c|c|c|c|c|c|c|c|c|c|c|}
\hline \multicolumn{2}{|r|}{ Termos } & \multicolumn{3}{|c|}{ ARTIGOS } & \multicolumn{3}{|c|}{ TESES } & \multicolumn{3}{|c|}{ DISSERTAÇÕES } & \multicolumn{3}{|c|}{ TRAB. EVENTOS } \\
\hline & & Ol & OC & $\mathrm{Ol} / \mathrm{OC}$ & Ol & $O C$ & Ol/OC & Ol & OC & $\mathrm{Ol} / \mathrm{OC}$ & $\mathrm{Ol}$ & OC & $\mathrm{Ol} / \mathrm{OC}$ \\
\hline 1. & $\begin{array}{r}\text { Abordagem } \\
\text { cognitiva. }\end{array}$ & - & & & - & & & - & & & 1 & & \\
\hline 2. & $\begin{array}{r}\text { Abordagem } \\
\text { onomasiológica }\end{array}$ & 1 & & & - & & & - & & & - & & \\
\hline 3. & $\begin{array}{r}\text { Abordagem } \\
\text { semasiológica }\end{array}$ & 1 & & & - & & & - & & & - & & \\
\hline 4. & $\begin{array}{r}\text { Abordagem } \\
\text { sócio-cognitiva }\end{array}$ & - & & & - & & & - & & & 1 & & \\
\hline 5. & $\begin{array}{r}\text { Abordagens } \\
\text { Socioculturais }\end{array}$ & & & & & & & & & & & 1 & \\
\hline 6. & $\begin{array}{r}\text { Acervo } \\
\text { fotográfico }\end{array}$ & 1 & & & - & & & - & & & - & & \\
\hline 7. & $\begin{array}{r}\text { Acervo } \\
\text { fotográfico } \\
\text { histórico } \\
\end{array}$ & 1 & & & - & & & - & & & - & & \\
\hline 8. & $\begin{array}{r}\text { Acessibilidade às } \\
\text { informaç̧ões } \\
\text { científicas }\end{array}$ & - & & & - & & & 1 & & & - & & \\
\hline 9. & $\begin{array}{l}\text { Administração } \\
\text { da informação }\end{array}$ & 1 & & & & & & & & & & & \\
\hline 10. & AERPA & & & & & & & & 1 & & & & \\
\hline 11. & $\begin{array}{r}\text { Afrodescendent } \\
\mathrm{e}\end{array}$ & & & & & & & 1 & & & & & \\
\hline 12. & $\begin{array}{r}\text { Ambientes } \\
\text { colaborativos }\end{array}$ & 1 & & & & & & & & & & & \\
\hline 13. & $\begin{array}{r}\text { Ambientes de } \\
\text { arte digital }\end{array}$ & & & & & & & & & 1 & & & \\
\hline 14. & $\begin{array}{r}\text { Análise } \\
\text { Conceitual }\end{array}$ & & 2 & & & & & & & & & & \\
\hline 15. & $\begin{array}{r}\text { Análise de } \\
\text { Assunto }\end{array}$ & & & & & & & & & & 1 & & \\
\hline 16. & $\begin{array}{l}\text { Análise de } \\
\text { conteúdo }\end{array}$ & 1 & & & & & & 2 & & & & & \\
\hline 17. & $\begin{array}{r}\text { Análise de } \\
\text { Domínio }\end{array}$ & 1 & 2 & & & & & & & 1 & & 1 & 1 \\
\hline 18. & $\begin{array}{r}\text { Análise do } \\
\text { acesso. }\end{array}$ & & & & & & & 1 & & & & & \\
\hline 19. & $\begin{array}{r}\text { Análise } \\
\text { documental }\end{array}$ & 1 & 1 & & & & & 1 & & & & & \\
\hline
\end{tabular}




\begin{tabular}{|c|c|c|c|c|c|c|c|c|c|c|c|c|c|}
\hline \multicolumn{2}{|r|}{ Termos } & \multicolumn{3}{|c|}{ ARTIGOS } & \multicolumn{3}{|c|}{ TESES } & \multicolumn{3}{|c|}{ DISSERTAÇÕES } & \multicolumn{3}{|c|}{ TRAB. EVENTOS } \\
\hline & & $\mathrm{OI}$ & OC & $\mathrm{OI} / \mathrm{OC}$ & Ol & $O C$ & $\mathrm{OI} / \mathrm{OC}$ & $\mathrm{OI}$ & OC & $\mathrm{Ol} / \mathrm{OC}$ & Ol & OC & $\mathrm{OI} / \mathrm{OC}$ \\
\hline 20. & $\begin{array}{r}\text { Análise } \\
\text { documentária de } \\
\text { imagem }\end{array}$ & & & & & & & 1 & & & & & \\
\hline 21. & Análise Facetada & & 1 & & & & & & & & & 2 & \\
\hline 22. & $\begin{array}{r}\text { Análise } \\
\text { documentária }\end{array}$ & & & & & & & & & 1 & 2 & & \\
\hline 23. & $\begin{array}{l}\text { Anotação } \\
\text { genômica }\end{array}$ & & 1 & & & & & & & & & & \\
\hline 24. & $\begin{array}{l}\text { Aquisição de } \\
\text { conhecimento }\end{array}$ & 1 & & & & & & & & & & & \\
\hline 25. & $\begin{array}{r}\text { Áreas do } \\
\text { conhecimento }\end{array}$ & & 1 & & & & & & & & & 1 & \\
\hline 26. & $\begin{array}{l}\text { Arquitetura da } \\
\text { informação }\end{array}$ & 3 & & 2 & & & & 1 & & & 1 & & \\
\hline 27. & $\begin{array}{r}\text { Arquitetura de } \\
\text { metadados } \\
\end{array}$ & & & & & & & & & & 1 & & \\
\hline 28. & $\begin{array}{r}\text { Arquitetura } \\
\text { orientada à } \\
\text { serviço }\end{array}$ & & & 1 & & & & & & & & & \\
\hline 29. & Arquivos & 1 & & & & & & & & & & & \\
\hline 30. & Artes digitais & & & & & & & & & & & & 1 \\
\hline 31. & Artigo científico & & & & & & & & & & 1 & & \\
\hline 32. & $\begin{array}{r}\text { Artigos } \\
\text { semânticos }\end{array}$ & & 1 & & & & & & & & & & \\
\hline 33. & Atinência & & & & & & & & 1 & & & & \\
\hline 34. & $\begin{array}{r}\text { Atribuição de } \\
\text { Palavras-chave }\end{array}$ & & & & & & & & & & 1 & & \\
\hline 35. & $\begin{array}{r}\text { Automação de } \\
\text { tesauros } \\
\end{array}$ & & & & & & & & & & 1 & & \\
\hline 36. & $\begin{array}{l}\text { Avaliação da } \\
\text { indexação. }\end{array}$ & & & & & & & 1 & & & & & \\
\hline 37. & $\begin{array}{r}\text { Avaliação de } \\
\text { sites }\end{array}$ & 1 & & & & & & & & & 1 & & \\
\hline 38. & Avaliação & & & & & & & 1 & & & & & \\
\hline 39. & Banco de dados & & & & & & & 1 & & & & & \\
\hline 40. & $\begin{array}{r}\text { Base de } \\
\text { conhecimento }\end{array}$ & & & & & & & & & & & 1 & \\
\hline 41. & Bdtd & 1 & & & & & & & & & & & \\
\hline 42. & Bibliometria & 2 & & & & & & & & & & & \\
\hline 43. & $\begin{array}{r}\text { Bibliotecas } \\
\text { digitais } \\
\end{array}$ & & 1 & & 1 & & & & 1 & & & & \\
\hline 44. & $\begin{array}{r}\text { Bibliotecas } \\
\text { escolares }\end{array}$ & 1 & & & & & & & & & & & \\
\hline 45. & Bibliotecas & 1 & & 1 & 1 & & & 2 & & & & & \\
\hline
\end{tabular}




\begin{tabular}{|c|c|c|c|c|c|c|c|c|c|c|c|c|c|}
\hline \multicolumn{2}{|r|}{ Termos } & \multicolumn{3}{|c|}{ ARTIGOS } & \multicolumn{3}{|c|}{ TESES } & \multicolumn{3}{|c|}{ DISSERTAÇÕES } & \multicolumn{3}{|c|}{ TRAB. EVENTOS } \\
\hline & & Ol & $O C$ & $\mathrm{Ol} / \mathrm{OC}$ & Ol & $O C$ & $\mathrm{OI} / \mathrm{OC}$ & $\mathrm{OI}$ & $O C$ & $\mathrm{Ol} / \mathrm{OC}$ & $\mathrm{Ol}$ & OC & $\mathrm{OI} / \mathrm{OC}$ \\
\hline & universitárias. & & & & & & & & & & & & \\
\hline 46. & Biblioteconomia & & & & & 1 & & 1 & & & & & \\
\hline 47. & $\begin{array}{r}\text { Biblioteconomia } \\
\text { e Ciência da } \\
\text { Informação }\end{array}$ & & & & & & & & & & & & 1 \\
\hline 48. & Big data & 1 & & & & & & & & & & & \\
\hline 49. & $\begin{array}{r}\text { Boletim de } \\
\text { ocorrência (B.O.) }\end{array}$ & & & & & & & 1 & & & & & \\
\hline 50. & Brasil & 1 & & & 1 & & & & & & & & \\
\hline 51. & $\begin{array}{r}\text { Busca da } \\
\text { informação }\end{array}$ & & & & & & & 1 & & & 1 & & \\
\hline 52. & $\begin{array}{r}\text { Busca e uso da } \\
\text { informação }\end{array}$ & & & & & & & & 1 & & & & \\
\hline 53. & Busca & & & & & & & 1 & & & & & \\
\hline 54. & Café & 1 & & & & & & & & & 1 & & \\
\hline 55. & Card sorting & 1 & & & & & & & & & & & \\
\hline 56. & $\begin{array}{r}\text { Cartografia } \\
\text { temática } \\
\end{array}$ & & 1 & & & & & & & & & & \\
\hline 57. & Catalogação & 2 & & & 1 & & & 1 & & & 1 & & \\
\hline 58. & $\begin{array}{r}\text { Catalogação de } \\
\text { assunto }\end{array}$ & 1 & & & & & & 1 & & & & & \\
\hline 59. & Catálogos & & & & & & & 1 & & & 1 & & \\
\hline 60. & Categoria & & 1 & & & 1 & & & 1 & & & 1 & \\
\hline 61. & Categorização & 1 & 1 & & & & & & 1 & & & 1 & \\
\hline 62. & $\begin{array}{r}\text { Categorização } \\
\text { filosófica }\end{array}$ & & & & & & & & 1 & & & 1 & \\
\hline 63. & $\begin{array}{r}\text { Categorização } \\
\text { semântico- } \\
\text { cognitiva } \\
\end{array}$ & & & & & & & & 1 & & & 1 & \\
\hline 64. & $\begin{array}{l}\text { Categorização } \\
\text { sócio-cultural }\end{array}$ & & & & & & & & 1 & & & & \\
\hline 65. & $\begin{array}{r}\text { Centros de } \\
\text { documentação }\end{array}$ & & & & & & & 1 & & & & & \\
\hline 66. & $\begin{array}{r}\text { Charles sanders } \\
\text { peirce (1839- } \\
1914)\end{array}$ & & & & & & & & & & 1 & & \\
\hline 67. & Ciberespaço & & 3 & & & & & & & & & 1 & \\
\hline 68. & Cibertecários & 1 & & & & & & & & & & & \\
\hline 69. & $\begin{array}{r}\text { Ciclo da } \\
\text { informação }\end{array}$ & & & & & & & & & & & 1 & \\
\hline 70. & Ciclo junino & & & & & & & & & & 1 & & \\
\hline 71. & Cidoc crm & & & & & & & & & & 1 & & \\
\hline 72. & $\begin{array}{l}\text { Ciência da } \\
\text { informação }\end{array}$ & 4 & 2 & 1 & 1 & 1 & & 9 & & & 3 & & \\
\hline
\end{tabular}




\begin{tabular}{|c|c|c|c|c|c|c|c|c|c|c|c|c|c|}
\hline \multicolumn{2}{|r|}{ Termos } & \multicolumn{3}{|c|}{ ARTIGOS } & \multicolumn{3}{|c|}{ TESES } & \multicolumn{3}{|c|}{ DISSERTAÇÕES } & \multicolumn{3}{|c|}{ TRAB. EVENTOS } \\
\hline & & Ol & $\mathrm{OC}$ & $\mathrm{Ol} / \mathrm{OC}$ & $\mathrm{Ol}$ & OC & Ol/OC & Ol & $\mathrm{OC}$ & $\mathrm{Ol} / \mathrm{OC}$ & $\mathrm{Ol}$ & OC & $\mathrm{Ol} / \mathrm{OC}$ \\
\hline 73. & $\begin{array}{r}\text { Ciência } \\
\text { eletrônica }\end{array}$ & & 1 & & & & & & & & & & \\
\hline 74. & $\begin{array}{r}\text { Ciência, } \\
\text { tecnologia e } \\
\text { sociedade } \\
\end{array}$ & & & & & & & 1 & & & & & \\
\hline 75. & $\begin{array}{l}\text { Ciências da } \\
\text { informação }\end{array}$ & 1 & & & & & & & & & & & \\
\hline 76. & $\begin{array}{r}\text { Ciências } \\
\text { Humanas }\end{array}$ & & 1 & & & & & & & & & & \\
\hline 77. & Ciências Sociais & & 1 & & & & & & & & & & \\
\hline 78. & Classe & & & & & 1 & & & & & & & \\
\hline 79. & Classificação & 1 & 1 & & 1 & 1 & & 1 & & & & & \\
\hline 80. & $\begin{array}{l}\text { Classificação } \\
\text { bibliográfica }\end{array}$ & 2 & & & & & & 1 & & & 1 & & \\
\hline 81. & $\begin{array}{r}\text { Classificação de } \\
\text { instrumentos } \\
\text { musicais }\end{array}$ & & & & & & & & & & 1 & & \\
\hline 82. & $\begin{array}{r}\text { Classificação } \\
\text { Decimal } \\
\text { Universal }\end{array}$ & & & & & & & & 1 & & & & \\
\hline 83. & $\begin{array}{l}\text { Classificação do } \\
\text { Conhecimento }\end{array}$ & & 1 & & & & & & & & & & \\
\hline 84. & $\begin{array}{r}\text { Classificação em } \\
\text { Ciência e } \\
\text { Tecnologia }\end{array}$ & & 2 & & & & & & & & & 1 & \\
\hline 85. & $\begin{array}{r}\text { Classificação em } \\
\text { Medicina }\end{array}$ & & & & & & & & & & & 1 & \\
\hline 86. & $\begin{array}{r}\text { Classificação } \\
\text { facetada }\end{array}$ & & 1 & & & & & 1 & & & & & \\
\hline 87. & $\begin{array}{r}\text { Classificação } \\
\text { Filosófica }\end{array}$ & & 1 & & & & & & & & & & \\
\hline 88. & $\begin{array}{r}\text { Classificações } \\
\text { em arquivos }\end{array}$ & 1 & & & & & & & & & & & \\
\hline 89. & Coleção & & & & & & & & & & 1 & & \\
\hline 90. & $\begin{array}{l}\text { Competência } \\
\text { classificatória }\end{array}$ & 1 & & & & & & & & & & & \\
\hline 91. & $\begin{array}{r}\text { Competência em } \\
\text { informação }\end{array}$ & & & & & & & 1 & & & & & \\
\hline 92. & Competitividade & & 1 & & & & & & & & & & \\
\hline 93. & $\begin{array}{l}\text { Comportamento } \\
\text { informacional }\end{array}$ & & & & & & & 2 & & & & & \\
\hline 94. & Comunicação & & 1 & & & & & 2 & & & & & \\
\hline 95. & $\begin{array}{r}\text { Comunicação } \\
\text { científica }\end{array}$ & 1 & & & & & & & & & 1 & & \\
\hline
\end{tabular}




\begin{tabular}{|c|c|c|c|c|c|c|c|c|c|c|c|c|c|}
\hline \multicolumn{2}{|r|}{ Termos } & \multicolumn{3}{|c|}{ ARTIGOS } & \multicolumn{3}{|c|}{ TESES } & \multicolumn{3}{|c|}{ DISSERTAÇÕES } & \multicolumn{3}{|c|}{ TRAB. EVENTOS } \\
\hline & & Ol & OC & $\mathrm{Ol} / \mathrm{OC}$ & $\mathrm{Ol}$ & OC & Ol/OC & $\mathrm{OI}$ & $\mathrm{OC}$ & $\mathrm{Ol} / \mathrm{OC}$ & $\mathrm{Ol}$ & $O C$ & OI/OC \\
\hline 96. & $\begin{array}{r}\text { Comunicação e } \\
\text { tecnologia }\end{array}$ & & & & & & & 1 & & & & & \\
\hline 97. & $\begin{array}{r}\text { Comunicação } \\
\text { empresa- } \\
\text { sociedade }\end{array}$ & & & & & & & & & & 1 & & \\
\hline 98. & $\begin{array}{l}\text { Comunicação } \\
\text { Organizacional }\end{array}$ & & 1 & & & & & & & & & & \\
\hline 99. & $\begin{array}{r}\text { Comunicação na } \\
\text { tecnologia }\end{array}$ & & & & & & & 1 & & & & & \\
\hline 100. & Conceito & & 2 & 1 & & & & & & & 1 & 1 & \\
\hline 101. & $\begin{array}{l}\text { Conceito de } \\
\text { informação }\end{array}$ & & 1 & & & & & & & & & & \\
\hline 102. & Conhecimento & & 2 & 1 & & & & & 1 & & & & \\
\hline 103. & $\begin{array}{r}\text { Conhecimento } \\
\text { científico }\end{array}$ & & 1 & & & & & & & & & & \\
\hline 104. & $\begin{array}{r}\text { Construção de } \\
\text { tesauros }\end{array}$ & 1 & & & & & & & & & & & \\
\hline 105. & $\begin{array}{r}\text { Compartilhamen } \\
\text { to da } \\
\text { informação e do } \\
\text { conhecimento }\end{array}$ & & & 1 & & & & & & & & & \\
\hline 106. & Corredor do café & 1 & & & & & & & & & & & \\
\hline 107. & $\begin{array}{r}\text { Criação da } \\
\text { informação }\end{array}$ & & & & & & & & & & 1 & & \\
\hline 108. & $\begin{array}{r}\text { Cultura } \\
\text { Amazônica } \\
\end{array}$ & & 1 & & & & & & & & & & \\
\hline 109. & $\begin{array}{r}\text { Cultura } \\
\text { organizacional }\end{array}$ & & & & & & & 1 & & & & & \\
\hline 110. & Currículo & & 1 & & & & & & & & & & \\
\hline 111. & Currículo lattes & & & & & & & & & & 1 & 1 & \\
\hline 112. & $\begin{array}{r}\text { Cutter, charles } \\
\text { ammi }\end{array}$ & & & & & & & 1 & & & & & \\
\hline 113. & $\begin{array}{l}\text { Defesa do } \\
\text { consumidor }\end{array}$ & & & & & & & 1 & & & & & \\
\hline 114. & Deficiência & & & & & & & 1 & & & & & \\
\hline 115. & Definição & 1 & & & & & & & & & & & \\
\hline 116. & $\begin{array}{r}\text { Desastres } \\
\text { naturais }\end{array}$ & & & & & & & 1 & & & & & \\
\hline 117. & Desclassificação & & 1 & & & & & & & & & & \\
\hline 118. & Descritores & & & & & & & 2 & & & & & \\
\hline 119. & $\begin{array}{r}\text { Desenvolviment } \\
\text { o social ciência, } \\
\text { tecnologia e } \\
\text { sociedade }\end{array}$ & & & & & & & 1 & & & & & \\
\hline
\end{tabular}




\begin{tabular}{|c|c|c|c|c|c|c|c|c|c|c|c|c|c|}
\hline \multirow{2}{*}{\multicolumn{2}{|c|}{\begin{tabular}{|c|}
$\begin{array}{l}\text { Tabela } 4 \text { - Termos que occ } \\
\text { da informação); OC (orga } \\
\text { conhecimento) }\end{array}$ \\
Termos \\
\end{tabular}}} & \multicolumn{3}{|c|}{ ARTIGOS } & \multicolumn{3}{|c|}{ TESES } & \multicolumn{3}{|c|}{ DISSERTAÇÕES } & \multicolumn{3}{|c|}{ TRAB. EVENTOS } \\
\hline & & $\mathrm{OI}$ & OC & $\mathrm{Ol} / \mathrm{OC}$ & $\mathrm{OI}$ & OC & Ol/OC & $\mathrm{Ol}$ & OC & $\mathrm{Ol} / \mathrm{OC}$ & $\mathrm{Ol}$ & OC & $\mathrm{Ol} / \mathrm{OC}$ \\
\hline 120. & Dialogismo & 1 & & & & & & & & & & 1 & \\
\hline 121. & Digitais & & & & & & & & & & & & 1 \\
\hline 122. & $\begin{array}{r}\text { Disseminação da } \\
\text { informação }\end{array}$ & & & & & & & 1 & & & & & \\
\hline 123. & $\begin{array}{r}\text { Dissertações e } \\
\text { Teses }\end{array}$ & & 1 & & & & & & & & & & \\
\hline 124. & Ditadura militar & & & & & & & 1 & & & & & \\
\hline 125. & $\begin{array}{r}\text { Diversidade } \\
\text { Cultural } \\
\end{array}$ & & & & & & & & & & & 1 & \\
\hline 126. & $\begin{array}{r}\text { Diversidade } \\
\text { Linguística }\end{array}$ & & & & & & & & & & & 1 & \\
\hline 127. & $\begin{array}{r}\text { Divulgação } \\
\text { científica } \\
\end{array}$ & 1 & & & & & & & & & & & \\
\hline 128. & $\begin{array}{l}\text { Documentação } \\
\text { de artes digitais }\end{array}$ & & & & & & & & & & & & 1 \\
\hline 129. & $\begin{array}{r}\text { Documentação } \\
\text { de arte }\end{array}$ & & & & & & & & & 1 & & & \\
\hline 130. & $\begin{array}{r}\text { Documentação } \\
\text { museológica }\end{array}$ & 1 & & & & & & & & & & & \\
\hline 131. & Documentação & & & 1 & & & & & & & & & \\
\hline 132. & $\begin{array}{r}\text { Documento } \\
\text { eletrônico } \\
\end{array}$ & 1 & & & & & & & & & 1 & & \\
\hline 133. & $\begin{array}{r}\text { Domínios } \\
\text { interdisciplinare } \\
\mathrm{s} \\
\end{array}$ & & & & & & & & & & & 1 & \\
\hline 134. & Dublin Core & & 1 & & & & & & & & & & \\
\hline 135. & $\begin{array}{r}\text { Educação a } \\
\text { distância } \\
\end{array}$ & & & & & & & & & & 1 & & \\
\hline 136. & Embrapa & & 1 & & & & & & & & & & \\
\hline 137. & Enancib & 1 & & & & & & & & & & & \\
\hline 138. & $\begin{array}{r}\text { Engenharia de } \\
\text { software }\end{array}$ & & & 1 & & & & & & & & & \\
\hline 139. & Ensino & 1 & & & & & & & & & & & \\
\hline 140. & Ensino Superior & & 1 & & & & & & & & & & \\
\hline 141. & $\begin{array}{l}\text { Ensino a } \\
\text { distância }\end{array}$ & & & & & & & 1 & & & & & \\
\hline 142. & $\begin{array}{r}\text { Epistemologia } \\
\text { da Ciência da } \\
\text { Informação }\end{array}$ & 1 & & & & & & & & & & & \\
\hline 143. & $\begin{array}{r}\text { Escola de Ciência } \\
\text { da Informação } \\
\text { da UFMG }\end{array}$ & 1 & & & & & & & & & & & \\
\hline 144. & $\begin{array}{l}\text { Escopo da } \\
\text { Ciência da }\end{array}$ & & 1 & & & & & & & & & & \\
\hline
\end{tabular}




\begin{tabular}{|c|c|c|c|c|c|c|c|c|c|c|c|c|c|}
\hline \multicolumn{2}{|r|}{ Termos } & \multicolumn{3}{|c|}{ ARTIGOS } & \multicolumn{3}{|c|}{ TESES } & \multicolumn{3}{|c|}{ DISSERTAÇÕES } & \multicolumn{3}{|c|}{ TRAB. EVENTOS } \\
\hline & & Ol & $\mathrm{OC}$ & OI/OC & Ol & OC & OI/OC & Ol & OC & $\mathrm{Ol} / \mathrm{OC}$ & Ol & OC & $\mathrm{Ol} / \mathrm{OC}$ \\
\hline & Informação & & & & & & & & & & & & \\
\hline 145. & Espanha & 1 & & & & & & & & & & & \\
\hline 146. & $\begin{array}{r}\text { Estatística } \\
\text { matemática. }\end{array}$ & & & & & & & 1 & & & & & \\
\hline 147. & Estatística & & & & & & & 1 & & & & & \\
\hline 148. & $\begin{array}{r}\text { Estrutura } \\
\text { organizacional }\end{array}$ & 1 & & & & & & & & & & & \\
\hline 149. & Estudo e ensino & & & & & & & 1 & & & & & \\
\hline 150. & $\begin{array}{l}\text { Estudos da } \\
\text { linguagem }\end{array}$ & 1 & & & & & & & & & & & \\
\hline 151. & $\begin{array}{r}\text { Estudos de } \\
\text { Usuário }\end{array}$ & & & & & & & 1 & & & & & \\
\hline 152. & $\begin{array}{r}\text { Etnometodologi } \\
\mathrm{a}\end{array}$ & & 1 & & & & & & & & & & \\
\hline 153. & Exomemória & & 1 & & & & & & & & & & \\
\hline 154. & Faceta & & & & & 1 & & & & & & & \\
\hline 155. & $\begin{array}{r}\text { Fernandes, } \\
\text { florestan, 1920- } \\
1995 \\
\end{array}$ & & & & & & & 1 & & & & & \\
\hline 156. & Festas populares & & & & & & & & & & 1 & & \\
\hline 157. & Filosofia & & 1 & & & & & & & & & & \\
\hline 158. & $\begin{array}{r}\text { Filosofia de } \\
\text { Peirce }\end{array}$ & & & & & & & & & & 1 & & \\
\hline 159. & $\begin{array}{r}\text { Fluxo de } \\
\text { informação }\end{array}$ & 1 & & & & & & & & & & & \\
\hline 160. & $\begin{array}{r}\text { Fluxo de } \\
\text { tratamento e } \\
\text { recuperação da } \\
\text { informação }\end{array}$ & & & & & & & 1 & & & & & \\
\hline 161. & Folksonomia & 5 & & & & & & & & & & & \\
\hline 162. & $\begin{array}{r}\text { Folksonomia e o } \\
\text { Profissional da } \\
\text { Informação }\end{array}$ & 1 & & & & & & & & & & & \\
\hline 163. & $\begin{array}{l}\text { Folksonomia na } \\
\text { Organização e } \\
\text { Representação } \\
\text { da Informação }\end{array}$ & 1 & & & & & & & & & & & \\
\hline 164. & $\begin{array}{r}\text { Fontes de } \\
\text { informação }\end{array}$ & 1 & & & & & & & & & & & \\
\hline 165. & $\begin{array}{r}\text { Formação } \\
\text { continuada }\end{array}$ & 1 & & & & & & & & & & & \\
\hline 166. & Fotografia & & & & & & & 3 & & & & & \\
\hline 167. & Frbroo & & & & & & & & & & 1 & & \\
\hline 168. & Fundamentos da & & 1 & 2 & & & & & & & & & \\
\hline
\end{tabular}




\begin{tabular}{|c|c|c|c|c|c|c|c|c|c|c|c|c|c|}
\hline \multicolumn{2}{|r|}{ Termos } & \multicolumn{3}{|c|}{ ARTIGOS } & \multicolumn{3}{|c|}{ TESES } & \multicolumn{3}{|c|}{ DISSERTAÇÕES } & \multicolumn{3}{|c|}{ TRAB. EVENTOS } \\
\hline & & Ol & OC & OI/OC & OI & OC & $\mathrm{Ol} / \mathrm{OC}$ & OI & $\mathrm{OC}$ & $\mathrm{Ol} / \mathrm{OC}$ & OI & OC & $\mathrm{OI} / \mathrm{OC}$ \\
\hline & $\begin{array}{r}\text { Ciência da } \\
\text { Informação }\end{array}$ & & & & & & & & & & & & \\
\hline 169. & $\begin{array}{r}\text { Garantia do } \\
\text { usurário }\end{array}$ & & 1 & & & & & & & & & & \\
\hline 170. & $\begin{array}{r}\text { Gênero } \\
\text { discursivo }\end{array}$ & & 1 & & & & & & & & & & \\
\hline 171. & $\begin{array}{r}\text { Geração do } \\
\text { conhecimento }\end{array}$ & & 1 & & & & & & & & & & \\
\hline 172. & $\begin{array}{l}\text { Gerenciamento } \\
\text { da informação }\end{array}$ & & & & & & & 1 & & & & & \\
\hline 173. & $\begin{array}{r}\text { Gestão da } \\
\text { informação }\end{array}$ & 1 & & 1 & & & & 3 & 2 & & & & \\
\hline 174. & $\begin{array}{r}\text { Gestão de } \\
\text { Documentos } \\
\text { Arquivísticos } \\
\end{array}$ & 1 & & & & & & & & & & & \\
\hline 175. & $\begin{array}{r}\text { Gestão do } \\
\text { conhecimento }\end{array}$ & & 4 & & & & & & 1 & & & & \\
\hline 176. & Gestão pública & & & & & & & 1 & & & & & \\
\hline 177. & Gilles Deleuze & & & & & & & & & & & 1 & \\
\hline 178. & Globalização & & 1 & & & & & & & & & & \\
\hline 179. & Glossários & & & & & & & 1 & & & & & \\
\hline 180. & $\begin{array}{l}\text { Grupo de } \\
\text { pesquisa }\end{array}$ & & 1 & & & & & & & & & & \\
\hline 181. & $\begin{array}{r}\text { Hipermodernida } \\
\text { de }\end{array}$ & & 1 & & & & & & & & & & \\
\hline 182. & Hipertexto & 1 & 1 & & & & & & & & & 2 & \\
\hline 183. & $\begin{array}{r}\text { História da } \\
\text { Biblioteconomia }\end{array}$ & 1 & & & & & & & & & & & \\
\hline 184. & $\begin{array}{r}\text { História da } \\
\text { Ciência da } \\
\text { Informação }\end{array}$ & 1 & & & & & & & & & & & \\
\hline 185. & $\begin{array}{r}\text { História da } \\
\text { Documentação }\end{array}$ & 1 & & & & & & & & & & & \\
\hline 186. & Historiografia & & 1 & & & & & & & & & & \\
\hline 187. & $\begin{array}{r}\text { Historiografia } \\
\text { museológica } \\
\end{array}$ & & & & 1 & & & & & & 1 & & \\
\hline 188. & Imagens & & & & & & & 2 & & & 1 & 1 & \\
\hline 189. & $\begin{array}{r}\text { Imagens } \\
\text { biomédicas }\end{array}$ & & & & & & & & & & 1 & & \\
\hline 190. & Indexação & 2 & 3 & & 2 & & & 1 & & & 4 & 1 & \\
\hline 191. & Indexação social & 1 & & & & & & & & & & & \\
\hline 192. & $\begin{array}{r}\text { Indicadores } \\
\text { bibliométricos }\end{array}$ & & 1 & & & & & & & & & & \\
\hline 193. & Informação & & 1 & & & & & & & & & & \\
\hline
\end{tabular}




\begin{tabular}{|c|c|c|c|c|c|c|c|c|c|c|c|c|c|}
\hline \multirow{2}{*}{\multicolumn{2}{|c|}{\begin{tabular}{|c|}
$\begin{array}{l}\text { Tabela } 4 \text { - Termos que occ } \\
\text { da informação); OC (orga } \\
\text { conhecimento) }\end{array}$ \\
Termos \\
\end{tabular}}} & \multicolumn{3}{|c|}{ ARTIGOS } & \multicolumn{3}{|c|}{ TESES } & \multicolumn{3}{|c|}{ DISSERTAÇÕES } & \multicolumn{3}{|c|}{ TRAB. EVENTOS } \\
\hline & & Ol & $\mathrm{OC}$ & $\mathrm{Ol} / \mathrm{OC}$ & $\mathrm{Ol}$ & OC & Ol/OC & OI & $\mathrm{OC}$ & $\mathrm{Ol} / \mathrm{OC}$ & $\mathrm{Ol}$ & $O C$ & OI/OC \\
\hline & como afeto & & & & & & & & & & & & \\
\hline 194. & $\begin{array}{l}\text { Informação } \\
\text { como um evento }\end{array}$ & & 1 & & & & & & & & & & \\
\hline 195. & $\begin{array}{r}\text { Informação } \\
\text { Documentária }\end{array}$ & & & & & & & & & & & 1 & \\
\hline 196. & $\begin{array}{r}\text { Informação em } \\
\text { saúde }\end{array}$ & & & & & & & & & & 1 & & \\
\hline 197. & $\begin{array}{l}\text { Informação } \\
\text { estratégica }\end{array}$ & 1 & & & & & & & & & & & \\
\hline 198. & $\begin{array}{l}\text { Informação } \\
\text { Étnico-racial }\end{array}$ & & & & & & & 1 & & & & & \\
\hline 199. & $\begin{array}{r}\text { Informação } \\
\text { gerencial }\end{array}$ & 1 & & & & & & & & & & & \\
\hline 200. & $\begin{array}{l}\text { Informação } \\
\text { institucional }\end{array}$ & & & & & & & 1 & & & & & \\
\hline 201. & $\begin{array}{r}\text { Informação } \\
\text { jurídica }\end{array}$ & 1 & & & & & & 1 & & & & & \\
\hline 202. & Informação & & 2 & 1 & & & & & 1 & & 1 & & \\
\hline 203. & $\begin{array}{r}\text { Inovação } \\
\text { tecnológica }\end{array}$ & & & 1 & & & & & & 1 & & & \\
\hline 204. & $\begin{array}{r}\text { Institucionalizaç } \\
\text { ão da Ciência da } \\
\text { Informação }\end{array}$ & & & & & & & 1 & & & & & \\
\hline 205. & Instituições & 1 & & & & & & & & & & & \\
\hline 206. & $\begin{array}{r}\text { Instrumentos } \\
\text { musicais }\end{array}$ & & & & & & & & & & 1 & & \\
\hline 207. & $\begin{array}{r}\text { Interdisciplinarid } \\
\text { ade }\end{array}$ & & & & & & & & & & 1 & & \\
\hline 208. & Interferência & & & 1 & & & & & & & & & \\
\hline 209. & Internet & 3 & 1 & & & & & & & & 1 & & \\
\hline 210. & $\begin{array}{r}\text { Interoperabilida } \\
\text { de semântica }\end{array}$ & & & & & & & & & & & 1 & \\
\hline 211. & Interpretação & & & & & & & 1 & & & & & \\
\hline 212. & Julius kaiser & 1 & & & & & & & & & & & \\
\hline 213. & Junta comercial & & & & & & & 1 & & & & & \\
\hline 214. & $\begin{array}{r}\text { Lâminas } \\
\text { histopatológicas }\end{array}$ & & & & & & & & & & 1 & & \\
\hline 215. & $\begin{array}{r}\text { Leitura } \\
\text { documental }\end{array}$ & & & & & & & 1 & & & & & \\
\hline 216. & Linguagem & 1 & & & & & & & & & & 1 & \\
\hline 217. & $\begin{array}{l}\text { Linguagem de } \\
\text { especialidade. }\end{array}$ & & & 1 & & & & & & 1 & 1 & & \\
\hline 218. & $\begin{array}{l}\text { Linguagem de } \\
\text { indexação }\end{array}$ & 1 & & & & & & & & & 2 & & \\
\hline
\end{tabular}




\begin{tabular}{|c|c|c|c|c|c|c|c|c|c|c|c|c|c|}
\hline \multicolumn{2}{|r|}{ Termos } & \multicolumn{3}{|c|}{ ARTIGOS } & \multicolumn{3}{|c|}{ TESES } & \multicolumn{3}{|c|}{ DISSERTAÇÕES } & \multicolumn{3}{|c|}{ TRAB. EVENTOS } \\
\hline & & Ol & OC & $\mathrm{Ol} / \mathrm{OC}$ & Ol & OC & OI/OC & Ol & OC & $\mathrm{Ol} / \mathrm{OC}$ & Ol & OC & Ol/OC \\
\hline 219. & $\begin{array}{r}\text { Linguagem de } \\
\text { organização da } \\
\text { informação }\end{array}$ & 1 & & & & & & & & & & & \\
\hline 220. & $\begin{array}{r}\text { Linguagem } \\
\text { documentária }\end{array}$ & 1 & 2 & 1 & 1 & & & 2 & 2 & & & 1 & \\
\hline 221. & $\begin{array}{r}\text { Linguística } \\
\text { Cognitiva }\end{array}$ & & 1 & & & & & & & & & & \\
\hline 222. & $\begin{array}{r}\text { Linguística } \\
\text { documentária }\end{array}$ & 1 & & & & & & & & 1 & 1 & & 1 \\
\hline 223. & $\begin{array}{r}\text { Linguística e } \\
\text { Ciência da } \\
\text { Inforamção }\end{array}$ & & & 1 & & & & & & & & & \\
\hline 224. & $\begin{array}{r}\text { Listas de } \\
\text { Cabeçalhos de } \\
\text { assuntos }\end{array}$ & 1 & & & & & & & & & & & \\
\hline 225. & Lógica & & 1 & & & & & & & & & & \\
\hline 226. & $\begin{array}{r}\text { Lógica } \\
\text { paraconsistente }\end{array}$ & & 1 & & & & & & & & & & \\
\hline 227. & $\begin{array}{r}\text { Logística } \\
\text { humanitária }\end{array}$ & & & & & & & 1 & & & & & \\
\hline 228. & Manual técnico & & & & & & & & & & 1 & & \\
\hline 229. & $\begin{array}{r}\text { Mapas } \\
\text { conceituais }\end{array}$ & & 1 & & & & & & & & 1 & 2 & \\
\hline 230. & $\begin{array}{r}\text { Material didático } \\
\text { impresso }\end{array}$ & & & & & & & 1 & & & & & \\
\hline 231. & $\begin{array}{r}\text { Matrizes de } \\
\text { linguagem }\end{array}$ & & 1 & & & & & & & & & & \\
\hline 232. & $\begin{array}{r}\text { Mecanismos de } \\
\text { Busca }\end{array}$ & & 4 & & & & & & & & & 1 & \\
\hline 233. & $\begin{array}{r}\text { Mediação da } \\
\text { informação }\end{array}$ & & & 1 & & & & & & & & & \\
\hline 234. & $\begin{array}{r}\text { Mediação } \\
\text { implícita da } \\
\text { informação } \\
\end{array}$ & & & & & & & 1 & & & & & \\
\hline 235. & Medicina & & & & & & & & & & & 1 & \\
\hline 236. & $\begin{array}{r}\text { Medicina } \\
\text { baseada em } \\
\text { evidências } \\
\end{array}$ & & & & & & & 1 & & & & & \\
\hline 237. & $\begin{array}{r}\text { Memória } \\
\text { coletiva } \\
\end{array}$ & & & & & & & 1 & & & & & \\
\hline 238. & Memória digital & & & & & & & & 1 & & & & \\
\hline 239. & Memória social & & & & & & & & & & & 1 & \\
\hline 240. & Memória virtual & & & & & & & & & & & 1 & \\
\hline 241. & Memória & & & & & & & 2 & & & & & \\
\hline
\end{tabular}




\begin{tabular}{|c|c|c|c|c|c|c|c|c|c|c|c|c|c|}
\hline \multicolumn{2}{|r|}{ Termos } & \multicolumn{3}{|c|}{ ARTIGOS } & \multicolumn{3}{|c|}{ TESES } & \multicolumn{3}{|c|}{ DISSERTAÇÕES } & \multicolumn{3}{|c|}{ TRAB. EVENTOS } \\
\hline & & Ol & OC & $\mathrm{Ol} / \mathrm{OC}$ & $\mathrm{Ol}$ & OC & Ol/OC & $\mathrm{OI}$ & $\mathrm{OC}$ & $\mathrm{Ol} / \mathrm{OC}$ & $\mathrm{Ol}$ & $O C$ & $\mathrm{Ol} / \mathrm{OC}$ \\
\hline 242. & $\begin{array}{r}\text { Mensagem de } \\
\text { correio } \\
\text { eletrônico. }\end{array}$ & & & & 1 & & & & & & & & \\
\hline 243. & Metadados & 2 & 1 & & & & & 1 & 2 & & & & \\
\hline 244. & Metáfora & 1 & 1 & & & & & & & & & & \\
\hline 245. & $\begin{array}{r}\text { Mineração de } \\
\text { palavras }\end{array}$ & & & & & & & & & & 1 & & \\
\hline 246. & $\begin{array}{l}\text { Modelagem da } \\
\text { informação }\end{array}$ & & & 1 & & & & & & & & & \\
\hline 247. & Modelização & & 1 & & & & & & & & & & \\
\hline 248. & $\begin{array}{r}\text { Modelo } \\
\text { conceitual }\end{array}$ & & 2 & & & & & & & & 1 & 2 & \\
\hline 249. & $\begin{array}{l}\text { Modelo de } \\
\text { representação. }\end{array}$ & & & & & & & & & & 1 & & \\
\hline 250. & $\begin{array}{r}\text { Modelo } \\
\text { Genérico de } \\
\text { Relacionamento } \\
\mathrm{s}(\mathrm{MGR}) \\
\end{array}$ & & & & & & & & & & 1 & & \\
\hline 251. & $\begin{array}{r}\text { Modelos de } \\
\text { busca }\end{array}$ & & & & & & & 2 & & & & & \\
\hline 252. & Modelos & & & & & & & 1 & & & 2 & & \\
\hline 253. & $\begin{array}{r}\text { Mudanças } \\
\text { currriculares }\end{array}$ & & & 1 & & & & & & & & & \\
\hline 254. & $\begin{array}{r}\text { Multidisciplinari } \\
\text { dade }\end{array}$ & & & & & & & 1 & & & & & \\
\hline 255. & $\begin{array}{r}\text { Mundialização } \\
\text { do saber }\end{array}$ & 1 & & & & & & & & & & & \\
\hline 256. & Museu & 1 & & & 1 & & & 1 & & & 1 & & \\
\hline 257. & Museu virtual & & & & & & & & & & 1 & & \\
\hline 258. & $\begin{array}{r}\text { Museu } \\
\text { Universitário }\end{array}$ & & & & & & & & 1 & & & & \\
\hline 259. & $\begin{array}{r}\text { Museus } \\
\text { históricos }\end{array}$ & & & & 1 & & & & & & & & \\
\hline 260. & $\begin{array}{r}\text { Navegação } \\
\text { hipertextual }\end{array}$ & & 1 & & & & & & & & & & \\
\hline 261. & $\begin{array}{r}\text { Necessidades de } \\
\text { informação }\end{array}$ & 1 & & & & & & 1 & & & 2 & 1 & \\
\hline 262. & Neurologia & & & & & & & & & & & 1 & \\
\hline 263. & $\begin{array}{r}\text { Norma ISSO } \\
25964 \\
\end{array}$ & & 1 & & & & & & & & & & \\
\hline 264. & $\begin{array}{r}\text { Novas } \\
\text { tecnologias } \\
\end{array}$ & & 1 & & & & & & & & & & \\
\hline 265. & $\begin{array}{r}\text { Número de } \\
\text { chamada }\end{array}$ & & & & & & & & & & 1 & & \\
\hline
\end{tabular}




\begin{tabular}{|c|c|c|c|c|c|c|c|c|c|c|c|c|c|}
\hline \multicolumn{2}{|r|}{ Termos } & \multicolumn{3}{|c|}{ ARTIGOS } & \multicolumn{3}{|c|}{ TESES } & \multicolumn{3}{|c|}{ DISSERTAÇÕES } & \multicolumn{3}{|c|}{ TRAB. EVENTOS } \\
\hline & & Ol & $\mathrm{OC}$ & $\mathrm{Ol} / \mathrm{OC}$ & $\mathrm{Ol}$ & OC & Ol/OC & OI & $\mathrm{OC}$ & $\mathrm{Ol} / \mathrm{OC}$ & $\mathrm{Ol}$ & $O C$ & $\mathrm{OI} / \mathrm{OC}$ \\
\hline 266. & Ontologia & 2 & 2 & & 2 & & & 1 & 1 & & 1 & 4 & \\
\hline 267. & $\begin{array}{r}\text { Ontologia de } \\
\text { fundamentação }\end{array}$ & & & & & & & & & & & 1 & \\
\hline 268. & Opac. & & & & & & & 1 & & & & & \\
\hline 269. & $\begin{array}{r}\text { Ordenação de } \\
\text { documentos }\end{array}$ & & & & & & & & & & 1 & & \\
\hline 270. & $\begin{array}{l}\text { Organizações do } \\
\text { terceiro setor }\end{array}$ & & & & & & & & 1 & & & & \\
\hline 271. & Outros & & & & & & & 1 & & & & & \\
\hline 272. & $\begin{array}{l}\text { Padronização } \\
\text { terminológica }\end{array}$ & & & & & & & & & & 1 & & \\
\hline 273. & Página inicial & 1 & & & & & & & & & & & \\
\hline 274. & Palavras-chave & & & & & & & 2 & & & 3 & & \\
\hline 275. & $\begin{array}{r}\text { Parâmetros } \\
\text { lógicos de } \\
\text { organização } \\
\end{array}$ & & 1 & & & & & & & & & & \\
\hline 276. & Paraná & & & & & & & 2 & & & & & \\
\hline 277. & Patchwork & & 1 & & & & & & & & & & \\
\hline 278. & Patologia geral & & & & & & & & & & 1 & & \\
\hline 279. & $\begin{array}{r}\text { Patrimônio } \\
\text { digital } \\
\end{array}$ & & & & & & & & & & & 1 & \\
\hline 280. & $\begin{array}{r}\text { Perfis } \\
\text { profissionais }\end{array}$ & & 1 & & & & & & & & & & \\
\hline 281. & $\begin{array}{l}\text { Periódico } \\
\text { eletrônico }\end{array}$ & & & & & & & & & & 1 & & \\
\hline 282. & Periódicos & & & & & & & 1 & & & & & \\
\hline 283. & $\begin{array}{r}\text { Periódicos } \\
\text { científicos } \\
\text { eletrônicos }\end{array}$ & & & & & & & 1 & & & 1 & & \\
\hline 284. & $\begin{array}{l}\text { Pesquisa } \\
\text { científica }\end{array}$ & & 1 & & & & & & & & & & \\
\hline 285. & $\begin{array}{r}\text { Pesquisa } \\
\text { experimental }\end{array}$ & & & & & & & 1 & & & & & \\
\hline 286. & $\begin{array}{r}\text { Pesquisa } \\
\text { municipal }\end{array}$ & & & & & & & 1 & & & & & \\
\hline 287. & Pesquisador & & & & & & & & 1 & & & & \\
\hline 288. & $\begin{array}{r}\text { Planejamento e } \\
\text { gestão de } \\
\text { Serviços } \\
\end{array}$ & 1 & & & & & & & & & & & \\
\hline 289. & Polícia & & & & & & & 1 & & & & & \\
\hline 290. & $\begin{array}{r}\text { Política } \\
\text { Científica }\end{array}$ & & & & & & & & & & & 1 & \\
\hline 291. & $\begin{array}{l}\text { Política de } \\
\text { Informação }\end{array}$ & & & & & & & 1 & & & & & \\
\hline
\end{tabular}




\begin{tabular}{|c|c|c|c|c|c|c|c|c|c|c|c|c|c|}
\hline \multicolumn{2}{|r|}{ Termos } & \multicolumn{3}{|c|}{ ARTIGOS } & \multicolumn{3}{|c|}{ TESES } & \multicolumn{3}{|c|}{ DISSERTAÇÕES } & \multicolumn{3}{|c|}{ TRAB. EVENTOS } \\
\hline & & Ol & $\mathrm{OC}$ & $\mathrm{Ol} / \mathrm{OC}$ & $\mathrm{OI}$ & $\mathrm{OC}$ & $\mathrm{Ol} / \mathrm{OC}$ & $\mathrm{Ol}$ & OC & $\mathrm{Ol} / \mathrm{OC}$ & $\mathrm{Ol}$ & OC & $\mathrm{OI} / \mathrm{OC}$ \\
\hline 292. & $\begin{array}{r}\text { Políticas de } \\
\text { indexação }\end{array}$ & 1 & & & & & & 1 & & & & & \\
\hline 293. & Posmodernidade & & & & & & & & & & & 1 & \\
\hline 294. & $\begin{array}{r}\text { Popularização da } \\
\text { Ciência }\end{array}$ & 1 & & & & & & & & & & & \\
\hline 295. & Portais da web & 1 & & & & & & & & & 1 & & \\
\hline 296. & $\begin{array}{r}\text { Portal } \\
\text { corporativo }\end{array}$ & & & & & & & & & & 1 & & \\
\hline 297. & Portal da CAPES & & & & & & & & & & 1 & & \\
\hline 298. & Portugal & 1 & & & & & & & & & & & \\
\hline 299. & PPGEGC/UFSC & & 1 & & & & & & & & & & \\
\hline 300. & Pragmática & & & & & & & & & & & 1 & \\
\hline 301. & $\begin{array}{r}\text { Pragmática } \\
\text { linguística }\end{array}$ & & & & & & & & & & & 1 & \\
\hline 302. & $\begin{array}{r}\text { Pragmatismo } \\
\text { americano } \\
\end{array}$ & & & & & & & & & & & 1 & \\
\hline 303. & $\begin{array}{r}\text { Práticas de } \\
\text { gestão do } \\
\text { conhecimento }\end{array}$ & & & & & & & & 1 & & & & \\
\hline 304. & $\begin{array}{r}\text { Preservação das } \\
\text { artes }\end{array}$ & & & & & & & & & & & & 1 \\
\hline 305. & $\begin{array}{r}\text { Preservação } \\
\text { digital }\end{array}$ & 1 & & & & & & & 1 & 1 & & & \\
\hline 306. & $\begin{array}{r}\text { Prevenção do } \\
\text { crime }\end{array}$ & & & & 1 & & & & & & & & \\
\hline 307. & Probabilidades & & & & & & & 1 & & & & & \\
\hline 308. & $\begin{array}{l}\text { Processo } \\
\text { decisório }\end{array}$ & & & & & & & & 1 & & & & \\
\hline 309. & $\begin{array}{r}\text { Processos } \\
\text { judiciais } \\
\end{array}$ & & & & & & & & & & 1 & & \\
\hline 310. & $\begin{array}{r}\text { Produção } \\
\text { bibliográfica }\end{array}$ & & & & & & & & & & 1 & & \\
\hline 311. & $\begin{array}{l}\text { Produção } \\
\text { científica }\end{array}$ & & & & & & & & & & 1 & & \\
\hline 312. & $\begin{array}{l}\text { Produção de } \\
\text { documentos }\end{array}$ & & & & 1 & & & & & & & & \\
\hline 313. & $\begin{array}{r}\text { Produção do } \\
\text { conhecimento }\end{array}$ & 1 & 1 & & & & & & & & & & \\
\hline 314. & $\begin{array}{r}\text { Profissional da } \\
\text { Informação }\end{array}$ & & 1 & & & & & & & & & & \\
\hline 315. & $\begin{array}{r}\text { Projeto de } \\
\text { pesquisa }\end{array}$ & 1 & & & & & & & & & & & \\
\hline 316. & Projeto Indexa & & 1 & & & & & & & & & & \\
\hline 317. & Projeto Scorpion & & 1 & & & & & & & & & & \\
\hline
\end{tabular}




\begin{tabular}{|c|c|c|c|c|c|c|c|c|c|c|c|c|c|}
\hline \multicolumn{2}{|r|}{ Termos } & \multicolumn{3}{|c|}{ ARTIGOS } & \multicolumn{3}{|c|}{ TESES } & \multicolumn{3}{|c|}{ DISSERTAÇÕES } & \multicolumn{3}{|c|}{ TRAB. EVENTOS } \\
\hline & & Ol & $\mathrm{OC}$ & $\mathrm{Ol} / \mathrm{OC}$ & $\mathrm{OI}$ & $\mathrm{OC}$ & Ol/OC & $\mathrm{OI}$ & $\mathrm{OC}$ & $\mathrm{Ol} / \mathrm{OC}$ & $\mathrm{Ol}$ & $O C$ & OI/OC \\
\hline 318. & $\begin{array}{r}\text { Prontuário de } \\
\text { paciente }\end{array}$ & & & 1 & & & & & & & 1 & & \\
\hline 319. & $\begin{array}{r}\text { Prontuário } \\
\text { Eletrônico do } \\
\text { Paciente }\end{array}$ & & & 1 & & & & & & & & & \\
\hline 320. & Protocolo verbal & & & & & & & 1 & & & & & \\
\hline 321. & Radlex & & & & & & & & & & & 1 & \\
\hline 322. & Ranganathan & & & & & & & & & & & & 1 \\
\hline 323. & RDF & & 1 & & & & & & & & & & \\
\hline 324. & $\begin{array}{r}\text { Recepção de } \\
\text { textos } \\
\text { pragmáticos }\end{array}$ & & & & & & & & & & & 1 & \\
\hline 325. & $\begin{array}{l}\text { Recuperação da } \\
\text { Informação }\end{array}$ & 4 & 2 & & 1 & & & 4 & & & 6 & 2 & \\
\hline 326. & $\begin{array}{r}\text { Rede de } \\
\text { informação }\end{array}$ & & & & & & & 1 & & & & & \\
\hline 327. & $\begin{array}{r}\text { Rede de } \\
\text { Informação } \\
\text { Científica }\end{array}$ & 1 & & & & & & & & & & & \\
\hline 328. & Rede SACl & & & & & & & 1 & & & & & \\
\hline 329. & Redes & 1 & & & & & & & & & & & \\
\hline 330. & $\begin{array}{r}\text { Redes de } \\
\text { conhecimento }\end{array}$ & 1 & & & & & & & & & & & \\
\hline 331. & Redes sociais & 2 & & & & & & & & & & & \\
\hline 332. & $\begin{array}{r}\text { Redes } \\
\text { semânticas }\end{array}$ & & 1 & & & & & & & & & & \\
\hline 333. & $\begin{array}{r}\text { Registros de } \\
\text { informação }\end{array}$ & & & & 1 & & & & & & & & \\
\hline 334. & Relacionamento & & & & & & & & & & 1 & & \\
\hline 335. & $\begin{array}{r}\text { Relações } \\
\text { conceituais } \\
\end{array}$ & & 1 & & & & & & & & & 1 & \\
\hline 336. & $\begin{array}{r}\text { Relações } \\
\text { semânticas }\end{array}$ & & & & & & & & & & & 1 & \\
\hline 337. & $\begin{array}{r}\text { Relato de } \\
\text { experiência }\end{array}$ & 1 & & & & & & & & & & & \\
\hline 338. & $\begin{array}{r}\text { Relatórios } \\
\text { técnicos }\end{array}$ & & & & & & & 1 & & & & & \\
\hline 339. & $\begin{array}{l}\text { Repositórios } \\
\text { institucionais }\end{array}$ & & & & & & & 2 & 1 & & 1 & 1 & \\
\hline 340. & $\begin{array}{r}\text { Representação } \\
\text { da informação }\end{array}$ & 5 & 3 & 2 & & & & 2 & & & 4 & 4 & 1 \\
\hline 341. & $\begin{array}{r}\text { Representação } \\
\text { descritiva }\end{array}$ & & & & 1 & & & & & & & & \\
\hline 342. & Representação & 1 & 9 & 2 & 5 & & & 2 & 1 & & 1 & 1 & 1 \\
\hline
\end{tabular}




\begin{tabular}{|c|c|c|c|c|c|c|c|c|c|c|c|c|c|}
\hline & \multirow[t]{2}{*}{ Termos } & \multicolumn{3}{|c|}{ ARTIGOS } & \multicolumn{3}{|c|}{ TESES } & \multicolumn{3}{|c|}{ DISSERTAÇÕES } & \multicolumn{3}{|c|}{ TRAB. EVENTOS } \\
\hline & & $\mathrm{OI}$ & $O C$ & $\mathrm{Ol} / \mathrm{OC}$ & $\mathrm{OI}$ & $\mathrm{OC}$ & $\mathrm{Ol} / \mathrm{OC}$ & $\mathrm{Ol}$ & OC & $\mathrm{Ol} / \mathrm{OC}$ & $\mathrm{OI}$ & $O C$ & $\mathrm{Ol} / \mathrm{OC}$ \\
\hline & $\begin{array}{r}\text { do } \\
\text { conhecimento }\end{array}$ & & & & & & & & & & & & \\
\hline 343. & $\begin{array}{l}\text { Representação } \\
\text { informacional. }\end{array}$ & & & & & & & & & & 1 & & \\
\hline 344. & $\begin{array}{l}\text { Representação } \\
\text { temática da } \\
\text { informação. }\end{array}$ & & & & & & & 1 & & & & & \\
\hline 345. & Representação. & & 1 & & & & & 1 & & & 1 & & \\
\hline 346. & $\begin{array}{r}\text { Representações } \\
\text { documentárias }\end{array}$ & & 1 & & & & & & & & & & \\
\hline 347. & Rizoma & & 4 & & & & & & & & & & \\
\hline 348. & $\begin{array}{r}\text { S@BER } \\
\text { Tecnologias } \\
\text { Educativas e } \\
\text { Sociais }\end{array}$ & & & & & & & & & & 1 & & \\
\hline 349. & Saúde & & & & & & & & & & 1 & & \\
\hline 350. & Saúde coletiva & & & & & & & & & 1 & & & \\
\hline 351. & Saúde pública & & & & & & & 1 & & & & & \\
\hline 352. & $\begin{array}{r}\text { Secretariado } \\
\text { executivo }\end{array}$ & & & & & & & 1 & & & & & \\
\hline 353. & $\begin{array}{l}\text { Segurança } \\
\text { pública }\end{array}$ & & & & & & & 1 & & & & & \\
\hline 354. & $\begin{array}{r}\text { Seleção } \\
\text { conceitual }\end{array}$ & & 1 & & & & & & & & & & \\
\hline 355. & Semântica & 1 & 1 & & & & & & & & & & \\
\hline 356. & Semiótica & & & & & & & & & & 3 & 1 & \\
\hline 357. & $\begin{array}{r}\text { Semiótica da } \\
\text { cultura } \\
\end{array}$ & & & & & & & & & & & 1 & \\
\hline 358. & $\begin{array}{r}\text { Serviço } \\
\text { Brasileiro de } \\
\text { Respostas } \\
\text { Técnicas }\end{array}$ & & & & & & & & & & 1 & & \\
\hline 359. & $\begin{array}{l}\text { Serviços de } \\
\text { Informação }\end{array}$ & & & & & & & 1 & & & & & \\
\hline 360. & $\begin{array}{r}\text { Serviços e } \\
\text { Produtos }\end{array}$ & 1 & & & & & & & & & & & \\
\hline 361. & $\begin{array}{r}\text { Sistema de } \\
\text { recuperação da } \\
\text { informação }\end{array}$ & & & & & & & 2 & & & & & \\
\hline 362. & $\begin{array}{r}\text { Sistema } \\
\text { memorial }\end{array}$ & & & & & & & 1 & & & & & \\
\hline 363. & $\begin{array}{l}\text { Sistemas de } \\
\text { classificação }\end{array}$ & 1 & 2 & & & & & & & & & & \\
\hline 364. & Sistemas de & 1 & 1 & 1 & & & & & & & & & \\
\hline
\end{tabular}




\begin{tabular}{|c|c|c|c|c|c|c|c|c|c|c|c|c|c|}
\hline \multirow{2}{*}{\multicolumn{2}{|c|}{\begin{tabular}{|c|}
$\begin{array}{l}\text { Tabela } 4 \text { - Termos que occ } \\
\text { da informação); OC (orga } \\
\text { conhecimento) }\end{array}$ \\
Termos
\end{tabular}}} & \multicolumn{3}{|c|}{ ARTIGOS } & \multicolumn{3}{|c|}{ TESES } & \multicolumn{3}{|c|}{ DISSERTAÇÕES } & \multicolumn{3}{|c|}{ TRAB. EVENTOS } \\
\hline & & Ol & OC & $\mathrm{Ol} / \mathrm{OC}$ & Ol & OC & Ol/OC & Ol & $\mathrm{OC}$ & $\mathrm{Ol} / \mathrm{OC}$ & OI & OC & OI/OC \\
\hline & Informação & & & & & & & & & & & & \\
\hline 365. & $\begin{array}{r}\text { Sistemas de } \\
\text { organização do } \\
\text { conhecimento }\end{array}$ & & 2 & & 1 & & & & 1 & & & & \\
\hline 366. & $\begin{array}{r}\text { Sistemas de } \\
\text { recuperação da } \\
\text { informação }\end{array}$ & 1 & & & & & & 2 & & & 1 & & \\
\hline 367. & $\begin{array}{l}\text { Sistemas de } \\
\text { representação }\end{array}$ & & & & & & & & & & & 1 & \\
\hline 368. & $\begin{array}{r}\text { Sistemas de } \\
\text { Representação } \\
\text { do } \\
\text { Conhecimento }\end{array}$ & 1 & & & & & & & & & & & \\
\hline 369. & $\begin{array}{r}\text { Sistemas } \\
\text { documentários }\end{array}$ & & & & 1 & & & & & & & & \\
\hline 370. & Sites da Web & & & & & & & 1 & & & & & \\
\hline 371. & $\begin{array}{r}\text { Sites de Pró- } \\
\text { Reitoria de } \\
\text { Graduação }\end{array}$ & 1 & & & & & & & & & & & \\
\hline 372. & $\begin{array}{r}\text { Sites de recursos } \\
\text { humanos }\end{array}$ & & & & & & & 1 & & & 1 & & \\
\hline 373. & $\begin{array}{l}\text { Sociedade do } \\
\text { conhecimento }\end{array}$ & & & & 1 & & & & & & & & \\
\hline 374. & Sustentabilidade & & 1 & & & & & & & & & & \\
\hline 375. & $\begin{array}{r}\text { Tabelas de } \\
\text { Classificação }\end{array}$ & & & & & & & & & & & & \\
\hline 376. & Taxonomia & 2 & 1 & & & & & & & & 1 & 1 & \\
\hline 377. & $\begin{array}{r}\text { Taxonomia } \\
\text { Facetada }\end{array}$ & & 1 & & & & & & & & & & \\
\hline 378. & $\begin{array}{l}\text { Tecnologia da } \\
\text { informação }\end{array}$ & 2 & 3 & & & & & & & & & & \\
\hline 379. & $\begin{array}{l}\text { Tecnologias de } \\
\text { informação e } \\
\text { comunicação }\end{array}$ & & & & & & & 1 & & & & & \\
\hline 380. & $\begin{array}{r}\text { Tecnologias } \\
\text { semânticas }\end{array}$ & 1 & & & 1 & & & & & & & & \\
\hline 381. & Tematicidade. & & & & & & & & 1 & & 1 & & \\
\hline 382. & Tempo & & & & & & & & & & & & 1 \\
\hline 383. & $\begin{array}{r}\text { Teoria } \\
\text { bibliográfica. }\end{array}$ & & & & & & & & & & 1 & & \\
\hline 384. & $\begin{array}{r}\text { Teoria da } \\
\text { classificação }\end{array}$ & 1 & & & & 1 & & & 1 & & & & \\
\hline 385. & $\begin{array}{r}\text { Teoria da } \\
\text { classificação }\end{array}$ & & 2 & & & & & & & & & 1 & \\
\hline
\end{tabular}




\begin{tabular}{|c|c|c|c|c|c|c|c|c|c|c|c|c|c|}
\hline \multicolumn{2}{|r|}{ Termos } & \multicolumn{3}{|c|}{ ARTIGOS } & \multicolumn{3}{|c|}{ TESES } & \multicolumn{3}{|c|}{ DISSERTAÇÕES } & \multicolumn{3}{|c|}{\begin{tabular}{l|l|} 
TRAB. EVENTOS \\
\end{tabular}} \\
\hline & & Ol & $\mathrm{OC}$ & $\mathrm{Ol} / \mathrm{OC}$ & Ol & OC & OI/OC & Ol & OC & $\mathrm{Ol} / \mathrm{OC}$ & Ol & OC & $\mathrm{Ol} / \mathrm{OC}$ \\
\hline & facetada & & & & & & & & & & & & \\
\hline 386. & $\begin{array}{r}\text { Teoria da } \\
\text { informação }\end{array}$ & & & & 4 & & & 1 & 1 & & & & \\
\hline 387. & $\begin{array}{l}\text { Teoria do } \\
\text { Conceito }\end{array}$ & & & 1 & & & & & & & 1 & & \\
\hline 388. & $\begin{array}{r}\text { Teoria do } \\
\text { conhecimento }\end{array}$ & & & & 1 & & & 1 & & & & & \\
\hline 389. & $\begin{array}{r}\text { Teoria dos Níveis } \\
\text { Integrativos }\end{array}$ & & & & & & & & & & & 1 & \\
\hline 390. & $\begin{array}{r}\text { Teorias de } \\
\text { representação }\end{array}$ & & 1 & & & & & & & & & & \\
\hline 391. & $\begin{array}{r}\text { Teorias } \\
\text { Semânticas }\end{array}$ & & 1 & & & & & & & & & & \\
\hline 392. & Terminologia & 1 & 2 & 1 & & & & & & 1 & 1 & 1 & \\
\hline 393. & Tesauro & 2 & 2 & & & & & & & & 1 & & \\
\hline 394. & $\begin{array}{r}\text { Tesauro } \\
\text { conceitual }\end{array}$ & & & & & & & & & & & 1 & \\
\hline 395. & $\begin{array}{r}\text { Tesauro em } \\
\text { Ciência da } \\
\text { Informação }\end{array}$ & 1 & & & & & & & & & & & \\
\hline 396. & $\begin{array}{r}\text { Teses e } \\
\text { Dissertações }\end{array}$ & 1 & & & & & & & & & & & \\
\hline 397. & Tipologia de KOS & & 1 & & & & & & & & & & \\
\hline 398. & Título & & & & & & & & & & 1 & & \\
\hline 399. & Topic maps & & & & & & & & & & 1 & & \\
\hline 400. & $\begin{array}{r}\text { Tomada de } \\
\text { decisão }\end{array}$ & & 1 & & & & & & & & & & \\
\hline 401. & $\begin{array}{l}\text { Transferência da } \\
\text { informação e do } \\
\text { conhecimento }\end{array}$ & & & & & & & & & & 1 & & \\
\hline 402. & $\begin{array}{r}\text { Tratamento da } \\
\text { informação }\end{array}$ & & & & & & & & & 1 & & & 1 \\
\hline 403. & $\begin{array}{r}\begin{array}{r}\text { Tratamento de } \\
\text { imagem }\end{array}\end{array}$ & & & & & & & 1 & & & & & \\
\hline 404. & $\begin{array}{l}\text { Tratamento } \\
\text { temático da } \\
\text { informação }\end{array}$ & 1 & 2 & & & & & 1 & & & 3 & & \\
\hline 405. & Ufpe & & & & & & & & & & 1 & & \\
\hline 406. & Universidade & & 1 & & & & & & & & & & \\
\hline 407. & $\begin{array}{r}\text { Universidades e } \\
\text { faculdades }\end{array}$ & & & & & & & 1 & & & & & \\
\hline 408. & $\begin{array}{r}\text { Universidades } \\
\text { estaduais }\end{array}$ & & & & & & & 1 & & & & & \\
\hline 409. & Usuários & 1 & & & & & & & & & & & \\
\hline
\end{tabular}




\begin{tabular}{|c|c|c|c|c|c|c|c|c|c|c|c|c|c|}
\hline \multicolumn{2}{|r|}{ Termos } & \multicolumn{3}{|c|}{ ARTIGOS } & \multicolumn{3}{|c|}{ TESES } & \multicolumn{3}{|c|}{ DISSERTAÇÕES } & \multicolumn{3}{|c|}{ TRAB. EVENTOS } \\
\hline & & $\mathrm{Ol}$ & $O C$ & $\mathrm{Ol} / \mathrm{OC}$ & OI & OC & Ol/OC & Ol & $\mathrm{OC}$ & $\mathrm{Ol} / \mathrm{OC}$ & Ol & $O C$ & Ol/OC \\
\hline 410. & $\begin{array}{l}\text { Usuários da } \\
\text { informação }\end{array}$ & 1 & & & & & & & & & & & \\
\hline 411. & $\begin{array}{r}\text { Vila Boa dos } \\
\text { Goyazes }\end{array}$ & & & & & & & & & & & 1 & \\
\hline 412. & Virtual & & 2 & & & & & & & & & & \\
\hline 413. & $\begin{array}{l}\text { Visualização da } \\
\text { Informação }\end{array}$ & 1 & & & & & & 1 & & & 1 & & \\
\hline 414. & $\begin{array}{r}\text { Vocabulário } \\
\text { controlado }\end{array}$ & & & & & & & & & & 2 & & \\
\hline 415. & $\begin{array}{r}\text { Vocabulários } \\
\text { biomédicos }\end{array}$ & 1 & & & & & & & & & & & \\
\hline 416. & Vocabulários & & & & & & & 1 & & & & & \\
\hline 417. & Web & 1 & & & & & & & & & & 2 & \\
\hline 418. & Web 2.0 & 1 & & & & & & & & & & & \\
\hline 419. & Web semântica & 2 & & & & & & & & & & 1 & \\
\hline 420. & Websites & 1 & & & & & & & & & & & \\
\hline 421. & World wide web & 2 & & & & & & 1 & & & & & \\
\hline 422. & $\mathrm{XML}$ & & 1 & & & & & & & & & & \\
\hline
\end{tabular}

